\title{
STATE OF THE CLIMATE IN 2020
}

\section{THE ARCTIC}

M. L. Druckenmiller, T. Moon, and R. Thoman, Eds.

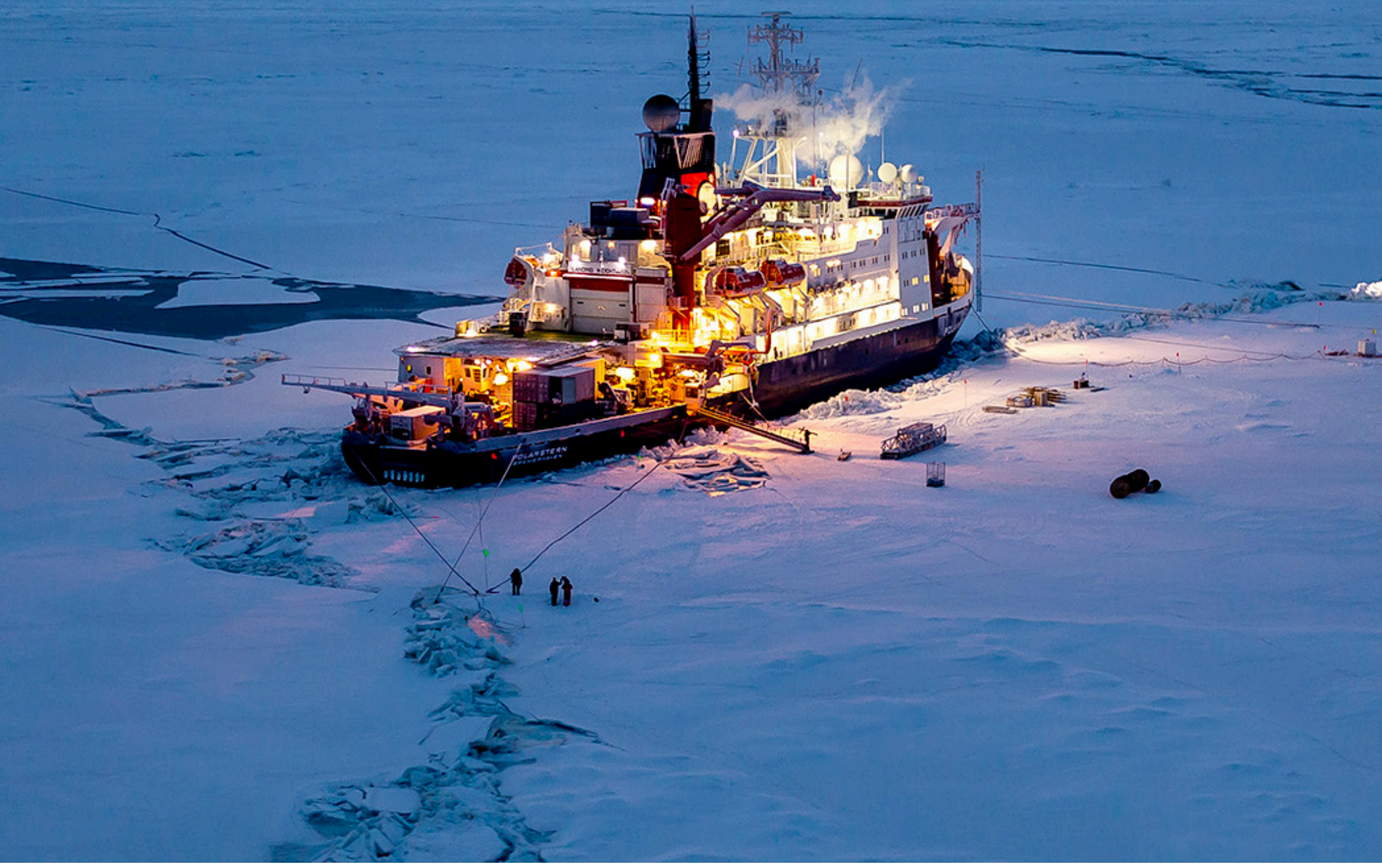

Special Online Supplement to the Bulletin of the American Meteorological Society Vol.102, No. 8, August, 2021

https://doi.org/10.1175/BAMS-D-21-0086.1

Corresponding author: Matthew L. Druckenmiller / druckenmiller@colorado.edu @2021 American Meteorological Society

For information regarding reuse of this content and general copyright information, consult the AMS Copyright Policy. 


\section{STATE OF THE CLIMATE IN 2020 \\ The Arctic}

\section{Editors}

Jessica Blunden

Tim Boyer

\section{Chapter Editors}

Freya Aldred

Peter Bissolli

Howard J. Diamond

Matthew L. Druckenmiller

Robert J. H. Dunn

Catherine Ganter

Nadine Gobron

Gregory C. Johnson

Rick Lumpkin

Tim Li

Ademe Mekonnen

John B. Miller

Twila A. Moon

Ahira Sánchez-Lugo

Ted A. Scambos

Carl J. Schreck III

Sharon Stammerjohn

Richard L. Thoman

Kate M. Willett

Technical Editor

Andrea Andersen

\section{BAMS Special Editor for Climate}

Michael A. Alexander

\section{American Meteorological Society}




\section{Cover credit:}

Stefan Hendricks / Alfred Wegener Institute CC-BY 4.0

Date: 2019-10-16-Location: Arctic Ocean, $84.765482^{\circ} \mathrm{N}, 133.905373^{\circ} \mathrm{E}$

The crew of the research icebreaker Polarstern inspects the ice anchors after a sea ice fracturing event at the early stages of the Multidisciplinary drifting Observatory for the Study of Arctic Climate (MOSAiC) experiment.

The Arctic is one chapter from the State of the Climate in 2020 annual report and is available from https://doi.org/10.1175/BAMS-D-21-0086.1. Compiled by NOAA's National Centers for Environmental Information, State of the Climate in 2020 is based on contributions from scientists from around the world. It provides a detailed update on global climate indicators, notable weather events, and other data collected by environmental monitoring stations and instruments located on land, water, ice, and in space.

The full report is available from https://doi.org/10.1175/2021BAMSStateoftheClimate.1.

\section{How to cite this document:}

\section{Citing the complete report:}

Blunden, J. and T. Boyer, Eds., 2021: "State of the Climate in 2020". Bull. Amer. Meteor. Soc., 102 (8), Si-S475, https://doi.org/10.1175/2021BAMSStateoftheClimate.1

\section{Citing this chapter:}

Druckenmiller, M. L., T. Moon, and R. Thoman, Eds., 2021: The Arctic [in "State of the Climate in 2020"]. Bull. Amer. Meteor. Soc., 102 (8), S263-S315, https://doi.org/10.1175/BAMS-D-21-0086.1

\section{Citing a section (example):}

Holmes, R. M., A. I. Shiklomanov, A. Suslova, M. Tretiakov, J. W. McClelland, L. Scott, R. G. M. Spencer, and S. E. Tank, 2021: River discharge [in "State of the Climate in 2020"]. Bull. Amer. Meteor. Soc., 102 (8), S290-S292, https://doi.org/10.1175/BAMS-D-21-0086.1. 
Ballinger, Thomas J., International Arctic Research Center, University of Alaska Fairbanks, Fairbanks, Alaska

Berner, Logan T., School of Informatics, Computing, and Cyber Systems, Northern Arizona University, Flagstaff, Arizona

Bernhard, Germar H., Biospherical Instruments Inc., San Diego, California

Bhatt, Uma S., Geophysical Institute, University of Alaska Fairbanks, Fairbanks, Alaska

Bjerke, Jarle W., Norwegian Institute for Nature Research, FRAM - High North Research Centre for Climate and the Environment, Tromsø, Norway

Box, Jason E., Geological Survey of Denmark and Greenland, Copenhagen, Denmark

Brown, R., Climate Research Division, Environment and Climate Change Canada, Montréal, Quebec, Canada

Cappelen, John, Danish Meteorological Institute, Copenhagen, Denmark

Christiansen, Hanne H., Geology Department, University Centre in Svalbard, The University Center in Svalbard, Longyearbyen, Norway

Decharme, B., Centre National de Recherches Météorologiques, Toulouse, France

Derksen, C., Climate Research Division, Environment and Climate Change Canada, Downsview, Ontario, Canada

Divine, Dmitry, Norwegian Polar Institute, Fram Centre, Tromsø, Norway

Drozdov, D. S., Earth Cryosphere Institute, and Tyumen State University, Tyumen, Russia

Druckenmiller, Matthew L., National Snow and Ice Data Center, Cooperative Institute for Research in Environmental Sciences at the University of Colorado, Boulder, Colorado

Elias Chereque, A., Department of Physics, University of Toronto, Toronto, Canada.

Epstein, Howard E., Department of Environmental Sciences, University of Virginia, Charlottesville, Virginia

Farquharson, L. M., Geophysical Institute, University of Alaska Fairbanks, Fairbanks, Alaska

Farrell, Sinead L., Department of Geographical Sciences, University of Maryland, College Park, Maryland

Fausto, Robert S., Geological Survey of Denmark and Greenland, Copenhagen, Denmark

Fettweis, Xavier, SPHERES research unit, University of Liège, Liège, Belgium

Fioletov, Vitali E., Environment and Climate Change Canada, Toronto, Ontario, Canada

Forbes, Bruce C., Arctic Centre, University of Lapland, Rovaniemi, Finland

Frost, Gerald V., ABR, Inc. Environmental Research \& Services, Fairbanks, Alaska

Gargulinski, Emily, National Institute of Aerospace, Resident at NASA LaRC, Hampton, Virginia

Gerland, Sebastian, Norwegian Polar Institute, Fram Centre, Tromsø, Norway

Goetz, Scott J., School of Informatics, Computing, and Cyber Systems, Northern Arizona University, Flagstaff, Arizona

Grabinski, Z., Alaska Fire Science Consortium, International Arctic Research Center, University of Alaska, Fairbanks, Alaska

Grooß, Jens-Uwe, Forschungszentrum Jülich, Jülich, Germany

Haas, Christian, Alfred Wegener Institute, Helmholtz Centre for Polar and Marine Research, Bremerhaven, Germany

Hanna, Edward, School of Geography and Lincoln Centre for Water and Planetary Health, University of Lincoln, Lincoln, United Kingdom

Hanssen-Bauer, Inger, Norwegian Meteorological Institute, Blindern, Oslo, Norway

Hendricks, Stefan, Alfred Wegener Institute, Helmholtz Centre for Polar and Marine Research, Bremerhaven, Germany

Holmes, Robert M., Woodwell Climate Research Center, Falmouth, Massachusetts
Ialongo, Iolanda, Finnish Meteorological Institute, Helsinki, Finland Isaksen, K., Norwegian Meteorlogical Institute, Blindern, Oslo, Norway Jain, Piyush, Natural Resources Canada, Canadian Forest Service, Northern Forestry Centre, Edmonton, Alberta, Canada

Johnsen, Bjørn, Norwegian Radiation and Nuclear Safety, Østerås, Norway

Kaleschke, L., Alfred Wegener Institute, Helmholtz Centre for Polar and Marine Research, Bremerhaven, Germany

Kholodov, A. L., Earth Cryosphere Institute, Tyumen Science Center, Tyumen, Russia

Kim, Seong-Joong, Korea Polar Research Institute, Incheon, Republic of Korea

Korsgaard, Niels J., Geological Survey of Denmark and Greenland, Copenhagen, Denmark

Labe, Zachary, Colorado State University, Fort Collins, Colorado

Lakkala, Kaisa, Finnish Meteorological Institute, Sodankylä, Finland

Lara, Mark J., Department of Plant Biology, University of Illinois at UrbanaChampaign, Urbana, Illinois

Loomis, Bryant, NASA Goddard Space Flight Center, Greenbelt, Maryland

Luojus, K., Arctic Research Centre, Finnish Meteorological Institute, Helsinki, Finland

Macander, Matthew J., ABR, Inc. Environmental Research \& Services, Fairbanks, Alaska

Malkova, G. V., Earth Cryosphere Institute, Tyumen Science Center, Tyumen, Russia

Mankoff, Kenneth D., Geological Survey of Denmark and Greenland, Copenhagen, Denmark

Manney, Gloria L., NorthWest Research Associates, Socorro, New Mexico

McClelland, James W., University of Texas at Austin, Marine Science Institute, Port Aransas, Texas

Meier, Walter N., National Snow and Ice Data Center, Cooperative Institute for Research in Environment Sciences at the University of Colorado, Boulder, Colorado

Moon, Twila A., National Snow and Ice Data Center, Cooperative Institute for Research in Environmental Sciences at the University of Colorado, Boulder, Colorado

Mote, Thomas, Department of Geography, University of Georgia, Athens, Georgia

Mudryk, L., Climate Research Division, Environment and Climate Change Canada, Downsview, Ontario, Canada

Müller, Rolf, Forschungszentrum Jülich, Jülich, Germany

Nyland, K. E., Department of Geography, George Washington University, Washington, D.C.

Overland, James E., NOAA/OAR Pacific Marine Environmental Laboratory, Seattle, Washington

Park, T., NASA Ames Research Center, Mountain View, California, and Bay Area Environmental Research Institute, Moffett Field, California

Pavlova, Olga, Norwegian Polar Institute, Fram Centre, Tromsø, Norway

Perovich, Don, Thayer School of Engineering, Dartmouth College, Hanover, New Hampshire

Petty, Alek, NASA Goddard Space Flight Center, Greenbelt, Maryland

Phoenix, Gareth K., Department of Animal and Plant Sciences, University of Sheffield, Sheffield, United Kingdom

Raynolds, Martha K., Institute of Arctic Biology, University of Alaska, Fairbanks, Alaska

Reijmer, C. H., Institute for Marine and Atmospheric Research Utrecht, Utrecht University, Utrecht, The Netherlands

Richter-Menge, Jacqueline, University of Alaska Fairbanks, Institute of Northern Engineering, Fairbanks, Alaska

Ricker, Robert, Alfred Wegener Institute, Helmholtz Centre for Polar and Marine Research, Bremerhaven, Germany 
Romanovsky, Vladimir E., Geophysical Institute, University of Alaska Fairbanks, Fairbanks, Alaska; Earth Cryosphere Institute, Tyumen Science Center, Tyumen, Russia

Scott, Lindsay, Woodwell Climate Research Center, Falmouth, Massachusetts Shapiro, Hazel, Arctic Research Consortium of the United States, Fairbanks, Alaska

Shiklomanov, Alexander I., University of New Hampshire, Durham, New Hampshire; Arctic and Antarctic Research Institute, St. Petersburg, Russia

Shiklomanov, Nikolai I., Department of Geography, George Washington University, Washington, D.C.

Smeets, C. J. P. P., Institute for Marine and Atmospheric Research Utrecht, Utrecht University, Utrecht, The Netherlands

Smith, Sharon L., Geological Survey of Canada, Natural Resources Canada, Ottawa, Ontario, Canada

Soja, Amber, National Institute of Aerospace, Resident at NASA LaRC, Hampton, Virginia

Spencer, Robert G. M., Florida State University, Tallahassee, Florida

Starkweather, Sandy, Cooperative Institute for Research in Environmental Sciences, University of Colorado Boulder and Earth System Research Laboratory, NOAA, Boulder, Colorado

Streletskiy, Dimitri A., Department of Geography, George Washington University, Washington, D.C.

Suslova, Anya, Woodwell Climate Research Center, Falmouth, Massachusetts Svendby, Tove, NILU-Norwegian Institute for Air Research, Kjeller, Norway

Tank, Suzanne E., University of Alberta, Edmonton, Alberta, Canada

Tedesco, Marco, Lamont Doherty Earth Observatory, Columbia University, Palisades, New York, and NASA Goddard Institute of Space Studies, New York, New York

Thoman, Richard L., International Arctic Research Center, University of Alaska Fairbanks, Fairbanks, Alaska

Tian-Kunze, X., Alfred Wegener Institute, Helmholtz Centre for Polar and Marine Research, Bremerhaven, Germany
Timmermans, Mary-Louise, Yale University, New Haven, Connecticut

Tømmervik, Hans, Norwegian Institute for Nature Research, FRAM and High North Research Centre for Climate and the Environment, Tromsø, Norway

Tretiakov, Mikhail, Arctic and Antarctic Research Institute, St. Petersburg, Russia

Tschudi, Mark, Aerospace Engineering Sciences, University of Colorado, Boulder, Colorado

Vakhutinsky, Sofia, National Snow and Ice Data Center, Cooperative Institute for Research in Environmental Sciences at the University of Colorado, Boulder, Colorado

van As, Dirk, Geological Survey of Denmark and Greenland, Copenhagen, Denmark

van de Wal, R. S. W., Institute for Marine and Atmospheric Research Utrecht and Department of Physical Geography, Utrecht University, Utrecht, The Netherlands

Veraverbeke, Sander, Faculty of Science, Vrije Universiteit Amsterdam, The Netherlands

Walker, Donald A., Institute of Arctic Biology, University of Alaska Fairbanks, Fairbanks, Alaska

Walsh, John E., International Arctic Research Center, University of Alaska Fairbanks, Fairbanks, Alaska

Wang, Muyin, NOAA/OAR Pacific Marine Environmental Laboratory, and Cooperative Institute for Climate, Ocean, and Ecosystem Studies, University of Washington, Seattle, Washington

Webster, Melinda, Geophysical Institute, University of Alaska Fairbanks, Fairbanks, Alaska

Winton, Øyvind, Geological Survey of Denmark and Greenland, Copenhagen, Denmark

Wood, K., NOAA, Pacific Marine Environmental Laboratory, Seattle, Washington

York, Alison, Alaska Fire Science Consortium, International Arctic Research Center, University of Alaska, Fairbanks, Alaska

Ziel, Robert, Alaska Fire Science Consortium, International Arctic Research Center, University of Alaska, Fairbanks, Alaska

\section{Editoral and Production Team}

Allen, Jessicca, Graphics Support, Cooperative Institute for Satellite Earth System Studies, North Carolina State University, Asheville, North Carolina

Andersen, Andrea, Technical Editor, Innovative Consulting and Management Services, LLC, NOAA/NESDIS National Centers for Environmental Information, Asheville, North Carolina

Hammer, Gregory, Content Team Lead, Communications and Outreach, NOAA/NESDIS National Centers for Environmental Information, Asheville, North Carolina

Love-Brotak, S. Elizabeth, Lead Graphics Production, NOAA/NESDIS National Centers for Environmental Information, Asheville, North Carolina
Misch, Deborah J., Graphics Support, Innovative Consulting and Management Services, LLC, NOAA/NESDIS National Centers for Environmental Information, Asheville, North Carolina

Riddle, Deborah B., Graphics Support, NOAA/NESDIS National Centers for Environmental Information, Asheville, North Carolina

Veasey, Sara W., Visual Communications Team Lead, Communications and Outreach, NOAA/NESDIS National Centers for Environmental Information, Asheville, North Carolina 


\section{Table of Contents}

List of authors and affiliations

S266

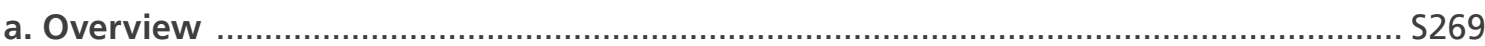

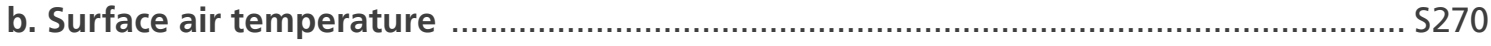

1. Mean annual surface air temperature over the terrestrial Arctic .................... S271

2. Seasonal air temperature patterns …........................................................... S271

Sidebar 5.1: Wildland fires in the high northern latitudes.............................................S274

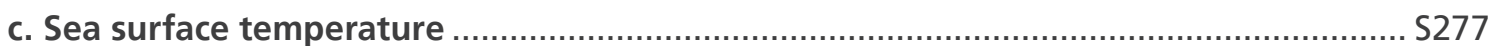

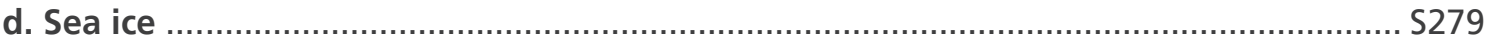

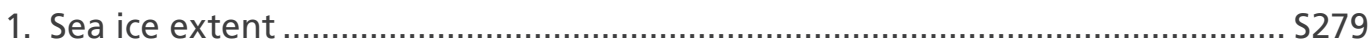

2. Sea ice thickness and volume ....................................................................... S281

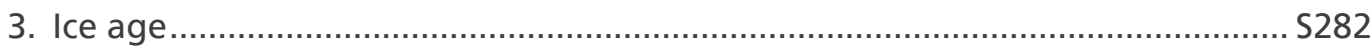

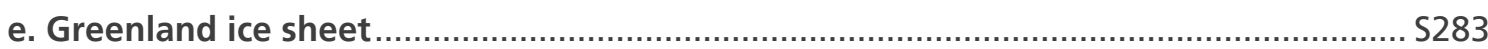

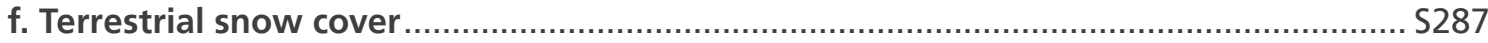

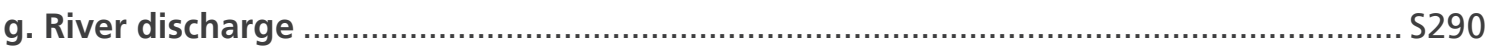

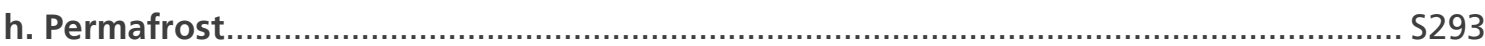

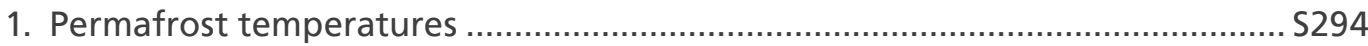

2. Active layer thickness............................................................................... S296

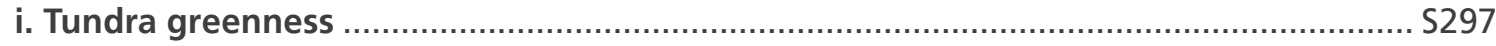

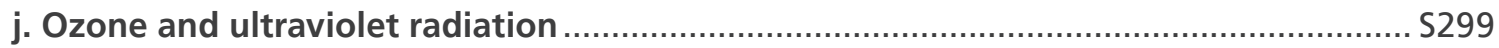

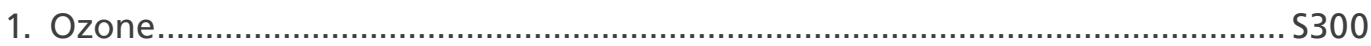

2. Ultraviolet radiation......................................................................................... S302

Sidebar 5.2: Assessing 15 years of Arctic Observing Network contributions to tracking key Arctic climate variables........................................................................ S304

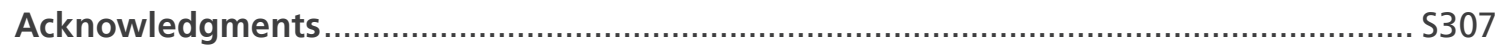

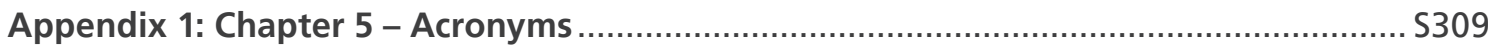

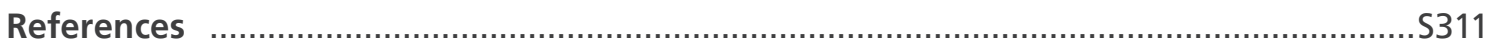

*Please refer to Chapter 8 (Relevant datasets and sources) for a list of all climate variables and datasets used in this chapter for analyses, along with their websites for more information and access to the data. 


\section{THE ARCTIC}

M. L. Druckenmiller, T. Moon, and R. Thoman, Eds.

a. Overview-M. L. Druckenmiller, T. Moon, J. Richter-Menge, and R. Thoman

The Arctic in 2020 was exceptionally warm. The annual mean surface air temperature (SAT) anomaly for land areas poleward of $60^{\circ} \mathrm{N}$ was $2.1^{\circ} \mathrm{C}$ above the $1981-2010$ average, marking the highest observed SAT anomaly for the terrestrial Arctic since at least 1900. It was also the seventh consecutive year with SAT anomalies of more than $+1^{\circ} \mathrm{C}$ higher than the 1981-2010 average. This continued increase in Arctic SAT is the primary driver for many of the changes observed on a pan-Arctic scale and enhanced regionally in any given year. During 2020, for example, warm SAT anomalies persisted from winter into summer across the Eurasian Arctic, contributing to early and widespread wildfire activity across the region and to the near-record sea ice retreat and warm summer and autumn sea surface temperatures (SSTs) in the Laptev and Kara Seas.

Arctic sea ice conditions in both winter and summer 2020 are consistent with a continued long-term transformation toward less sea ice across the Arctic, with reductions in extent and thickness. Most notably, the minimum summer ice extent was the second lowest in the 42-year satellite record, behind only 2012. Satellite-derived sea ice observations during the 2019/20 winter growth season revealed a near-record low ice volume since the collection of this data began in 2010. Observations of ice age, which are a proxy for ice thickness, confirm a longer-term substantial loss of Arctic sea ice volume, with the percentage of ice less than 3 years old in March shrinking from roughly a third to less than $10 \%$ of the entire ice cover since 1985. This shift toward younger, and thus thinner, sea ice results in an Arctic-wide ice cover that is more responsive to transient and seasonal scale atmospheric conditions and more vulnerable to melting out in summer.

As high-albedo (brighter, more reflective) sea ice is replaced by a low-albedo (darker, less reflective) open-water surface, incoming solar radiation is absorbed in the surface water rather than being reflected back to space. This ice-albedo feedback mechanism remains a dominant feature of accelerated Arctic climate and environmental change and is strongly indicated by sustained warming in summer SSTs. Elevated SSTs closely track with Arctic waters experiencing sea ice loss in early summer and also play a role in delaying autumn freeze-up and increasing ocean heat storage into the following year. Over much of the Arctic Ocean, mean SSTs in August 2020 were consistent with statistically significant warming trends up to $+0.1^{\circ} \mathrm{C} \mathrm{yr}^{-1}$ from 1982 to 2020 . Within the Arctic Ocean's marginal seas, mean August 2020 SSTs were around $1^{\circ}-3^{\circ} \mathrm{C}$ warmer than the 1982-2010 mean. The Laptev and Kara Seas, in particular, experienced the largest SST anomalies, up to $+5.5^{\circ} \mathrm{C}$ above the $1982-2010$ August mean, due to the region's exceptionally low summer sea ice extents.

On land, Arctic observations from 2020 also point to the transformative role of increasing Arctic surface air temperatures across terrestrial and freshwater systems. Prominent spring warming over Eurasia contributed to regional snow cover extent (SCE) anomalies that were the fourth lowest and record lowest in May and June, respectively, for the 54-year record. While relatively less extreme, SCE anomalies over North America were also below average in both May and June (eighth and 10th lowest, respectively). Together with surface air temperatures and precipitation patterns, snow cover characteristics influence a range of surface and ecological processes, including the ground thermal regime, vegetation dynamics, and freshwater budgets. For the majority of permafrost monitoring sites across the Arctic, reported temperatures in 2020 were the highest on 
record, continuing a long-term trend toward warming ground temperatures in all regions. While the productivity of Arctic tundra vegetation experiences considerable regional variability across years, the overall circumpolar trend in "greening" has remained positive since observations began in the early 1980s, with nine of the last 10 growing seasons exceeding the mean of the last 21 years of observations. Arctic river discharge observations from 2020 continue to reveal the intensification of the Arctic hydrologic cycle, with Eurasian and North American Arctic average annual river discharge increasing by 4.4 and $1.0 \mathrm{~km}^{3} \mathrm{yr}^{-1}$, respectively, since 1976. The combined river discharge in 2020 from the eight largest Arctic rivers was $~ 12 \%$ greater than the 1981-2010 reference period, owing $44 \%$ of this increase to the anomalously high discharge from the two largest North American rivers-the Mackenzie and Yukon.

For the Greenland ice sheet, which holds the equivalent of $7.4 \mathrm{~m}$ of potential sea level rise, various observations track the rate and extent of ice melt and overall mass loss. Using satellitebased measurements of gravity anomalies, indirect measurements of total mass loss since 2002 reveal a mean loss rate of $-268 \pm 14 \mathrm{Gt} \mathrm{yr}^{-1}$, which accounts for $\sim 0.8 \mathrm{~mm} \mathrm{yr}^{-1}$ of global mean sea level rise. In 2020, an overall ice loss of $-293 \pm 66$ Gt was only moderately more than the 2002-19 mean. The moderate rate of ice loss was due in part to both summer atmospheric circulation patterns that promoted near- to below-mean air temperatures in the ice sheet interior and the absence of unusually large melt events, even though the cumulative summer melt-day extent was $28 \%$ higher than the 1981-2010 mean.

Throughout this chapter, sustained and long-term observations illuminate the rapid pace and persistence of Arctic change and its far-reaching societal and ecological implications (Thoman et al. 2020). The value of long-term observation is revealed not only in the context of prominent surface processes that are transforming the cryosphere, but also for the entire Arctic system and its global connections. For example, Arctic stratospheric ozone concentrations from February through May 2020 were the lowest in the corresponding satellite record, which began in 2004, drawing attention to the human health and environment effects of increasing ultraviolet radiation reaching the Earth's surface. Arctic observations are also often marked by regional differences (e.g., continental scale differences in snow cover and terrestrial greening), indicating a complex and variable system that requires local and regional observing strategies that feed into and complement Arctic-wide assessments.

b. Surface air temperature-T. J. Ballinger, J. E. Overland, M. Wang, M. A. Webster, U. S. Bhatt, E. Hanna,

I. Hanssen-Bauer, S.-J. Kim, R. L. Thoman, and J. E. Walsh

Surface air temperatures (SAT), generally measured at a height of $2 \mathrm{~m}$, are one of the foremost Arctic change indicators (Box et al. 2019), with ongoing boreal warming effects felt across the global climate system (Moon et al. 2019). While terrestrial Arctic SAT patterns vary seasonally and interannually, the overall trend has been positive since the 1970s (Fig. 5.1). This warming

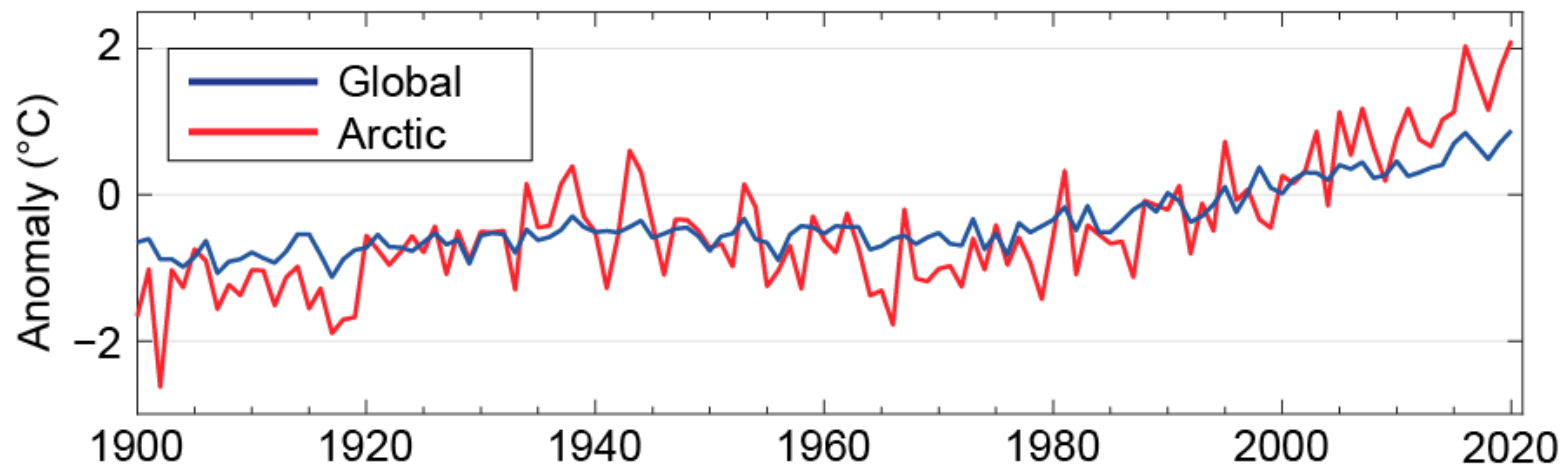

Fig. 5.1. Mean annual (Jan-Dec) SAT anomalies $\left({ }^{\circ} \mathrm{C}\right)$ for terrestrial weather stations located in the Arctic $\left(60^{\circ}-90^{\circ} \mathrm{N}\right.$; red line) and globally (blue line) for the 1900-2020 period. Both time series are presented with respect to their 1981-2010 mean SAT values. (Source: CRUTEM4; Jones et al. 2012.) 
has dramatically impacted the Arctic system, most notably through the decline of sea ice extent and thickness (Stroeve and Notz 2018; section 5d), decrease in snow cover (Cohen et al. 2020; section 5f), loss of glacial ice (Hanna et al. 2020; section 5e), and increase in permafrost thaw (Biskaborn et al. 2019; section 5h). Arctic ecosystems are also highly sensitive to SAT trends and extreme temperature events. For example, increased trends in terrestrial vegetation productivity and "greening" of the Arctic tundra (section 5i) are closely linked with Arctic SAT warming (Myers-Smith et al. 2020).

Intense Arctic temperature anomalies characterized 2020, as evidenced by the highest mean annual terrestrial SAT anomaly since the start of the record in 1900 (Fig. 5.1). In northern Eurasia-beginning in winter and continuing into spring and summer-the region's persistent warm anomalies were underscored by the late June heat wave in north-central Siberia (Overland and Wang 2021; section 7g2). Sustained abnormal temperatures played a major role in the region's vigorous wildfire activity, as detailed in Sidebar 5.1, and the near-record summertime sea ice melt and warm sea surface temperatures (SSTs) in the Laptev and Kara Seas (section 5c). Continued warm anomalies atop the Barents and Kara Seas during autumn were associated with an upper-level ridge of high pressure and an Arctic-midlatitude linkage event in December that brought widespread cold to eastern Asia and the North Pacific.

\section{1) Mean annual surface air temperature over the terrestrial Arctic}

In 2020, the Arctic annual mean SAT anomaly for terrestrial areas poleward of $60^{\circ} \mathrm{N}$ was $2.1^{\circ} \mathrm{C}$ above the 1981-2010 average (Fig. 5.1). This marked the highest-observed SAT anomaly for the terrestrial Arctic since at least 1900 and continued a pattern of seven consecutive years (and 8 of the last 10 years) where SAT anomalies were more than $1^{\circ} \mathrm{C}$ higher than the 1981-2010 average. Arctic warming has consistently outpaced global air temperature warming since 2000 (Fig. 5.1) due to Arctic amplification, a phenomenon driven by multiple processes that operate on different space and time scales (Overland et al. 2021). For example, seasonally variable mechanisms within the Arctic, such as ice-albedo and cloud-radiative feedbacks, play a critical role in modifying air temperatures (Cohen et al. 2020).

\section{2) Seasonal air temperature patterns}

Seasonal patterns of near-surface air temperature anomalies are shown for the winter (January-March), spring (April-June), summer (July-September), and autumn (October-December) of 2020 (Fig. 5.2). These seasonal divisions roughly coincide with annual cycles of the Arctic cryosphere, such as the onset of snowmelt and sea ice retreat during spring and their advances during autumn.

Winter was characterized by above-average temperatures stretching from eastern Europe to central Siberia. An extensive area of $+3^{\circ}$ to $+5^{\circ} \mathrm{C}$ air temperature anomalies occurred in northcentral Siberia (Fig. 5.2a). In contrast, areas extending eastward from Alaska to Greenland and Svalbard showed abnormally cold air temperatures.

Aligned with the highest winter Arctic Oscillation since records began in 1950 (Ballinger et al. 2020), a zonal polar jet stream in 2020 yielded westerly winds, stormy weather, and relatively mild northern Eurasian temperatures, while constraining colder-than-normal air over Alaska and portions of northern Canada (Fig. 5.3a). Frequent warm air intrusions into Eurasia were the product of anomalous cyclone activity, with records set for above-average winter storm occurrence and intensity over the Kara Sea and adjacent terrestrial areas (Figs. 5.4a,b). The anomalous atmospheric circulation pattern and storminess impacted the Multidisciplinary drifting Observatory for the Study of Arctic Climate (MOSAiC) Expedition, accelerating the icebreaker's drift across the central Arctic Ocean (approximately three times faster than Nansen's historic Fram expedition in the 1890s along a similar route; Shupe et al. 2020). 

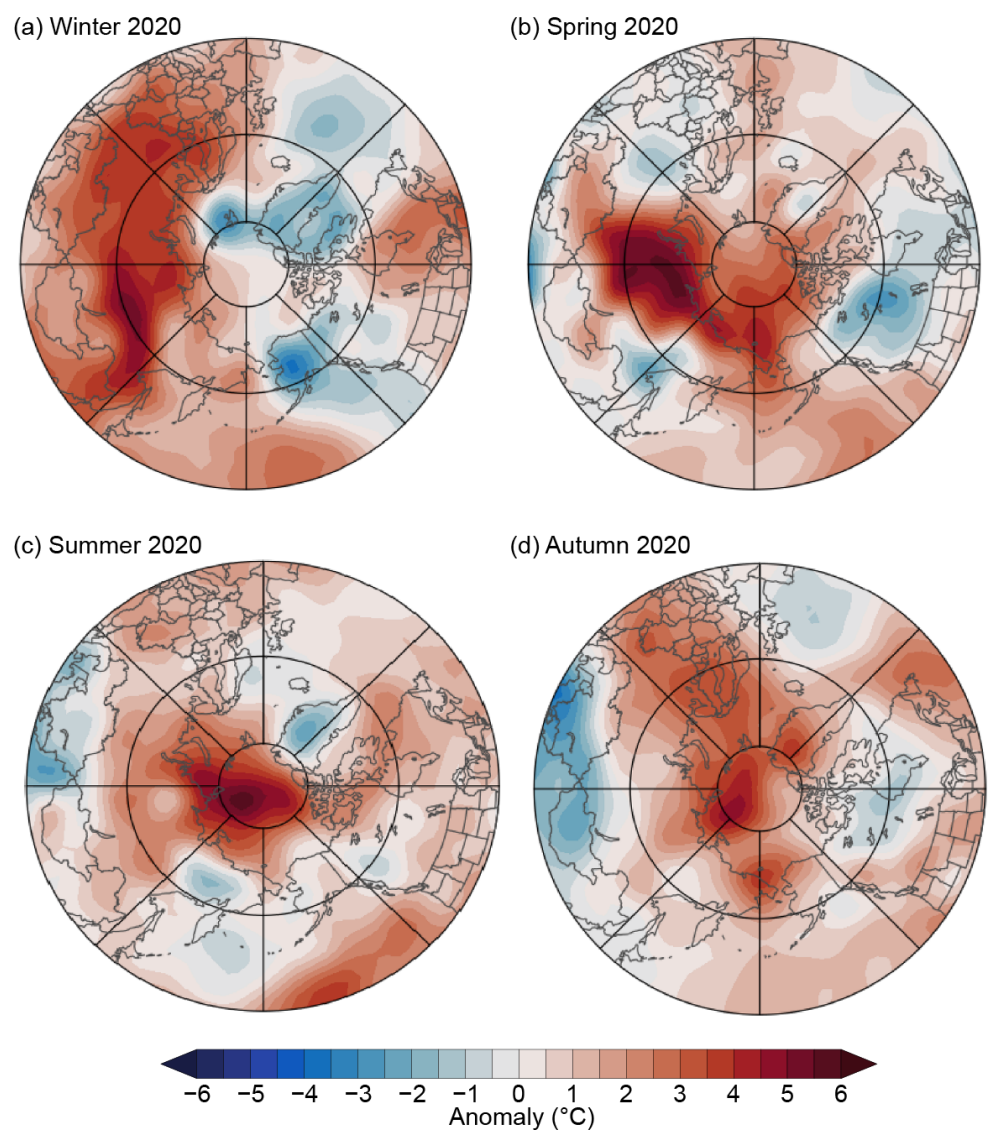

Fig. 5.2. Near-surface $(925-\mathrm{hPa})$ seasonal air temperature anomalies $\left({ }^{\circ} \mathrm{C}\right)$ for 2020 relative to the $1981-2010$ base period for (a) winter, (b) spring, (c) summer, and (d) autumn. The 925-hPa layer is used to emphasize large spatial temperature patterns, rather than local surface features. (Source: NCEP/NCAR Reanalysis; Kalnay et al. 1996.)
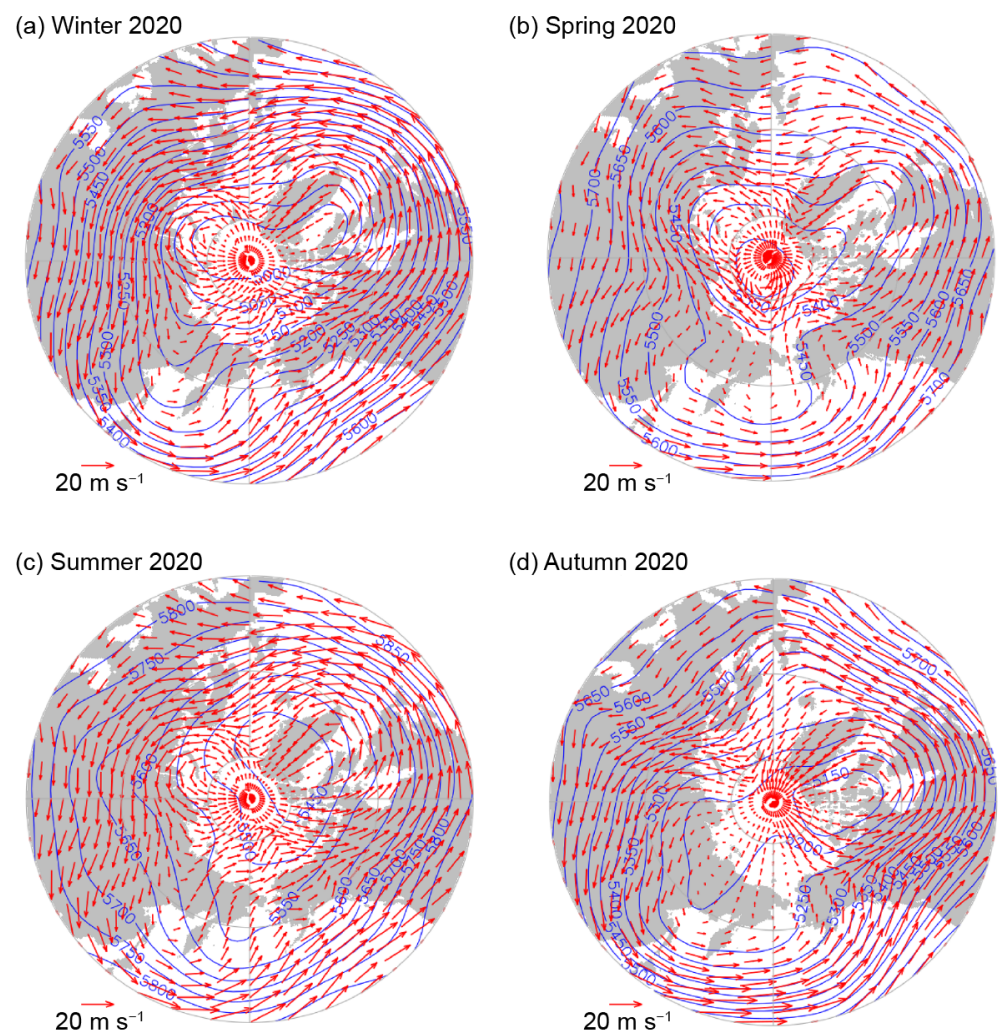

Fig. 5.3. Atmospheric circulation patterns described by $500-\mathrm{hPa}$ geopotential heights (GPH; $\mathrm{m}$, blue contours) and $500-\mathrm{hPa}$ winds (red vectors) for (a) winter, (b) spring, (c) summer, and (d) autumn of 2020. The wind vector scale indicates winds of $20 \mathrm{~m} \mathrm{~s}^{-1}$. (Source: NCEP/NCAR Reanalysis; Kalnay et al. 1996.) 

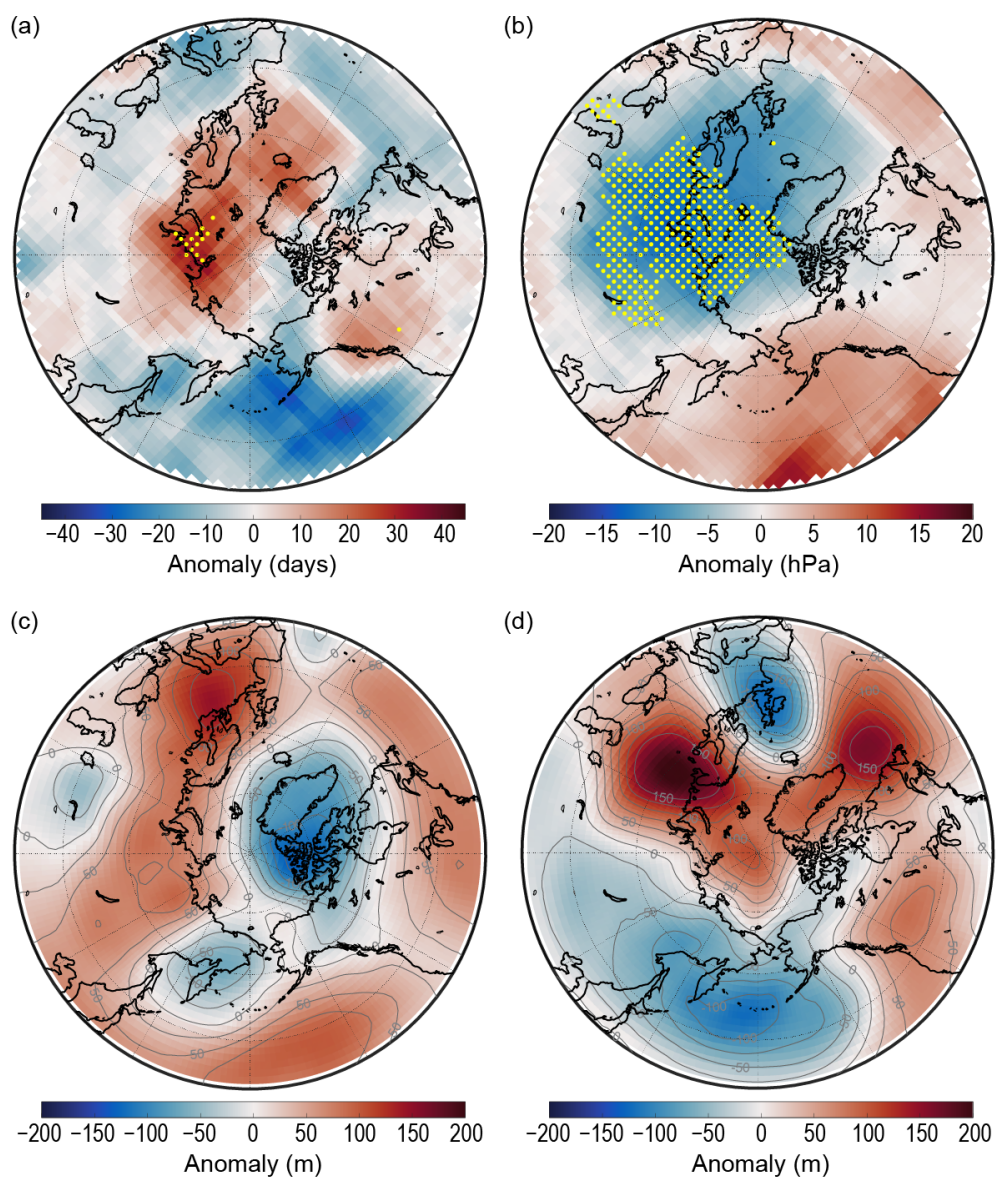

Fig. 5.4. Arctic atmospheric extremes during 2020. (a) Winter cyclone count (number of days with cyclone activity) anomalies and (b) cyclone intensity (minimum cyclone sea-level pressure [SLP], hPa) anomalies, relative to their respective 1981-2010 means. Yellow dots mark areas with the highest cyclone counts and the lowest seasonal average of minimum SLP within cyclones, respectively, during winter 2020. (Source: ERA5 SLP data is from Hersbach et al. 2020, and the cyclone methods are described in Webster et al. 2019.) (c) November and (d) December 500-hPa geopotential height anomalies (m), relative to the 1981-2010 mean, provide a snapshot of the evolving autumn meridional jet stream pattern that caused a cold outbreak over East Asia and the North Pacific in December 2020. (Source: ERA5 Reanalysis; Hersbach et al. 2020.)

Warm air temperature anomaly patterns covered much of the Arctic Ocean and coastal areas during spring (Fig. 5.2b). At $+5^{\circ} \mathrm{C}$, north-central Siberian air temperature anomalies remained far above normal. Late June was especially warm in the region, with a new record high station SAT (since 1885) of $38^{\circ} \mathrm{C}$ observed at Verkhoyansk, Russia, on 20 June (Overland and Wang 2021). Northward warm air advection fed by an upstream trough of low pressure over Europe (Fig. 5.3b) led to record low Eurasian Arctic spring snow cover extent (section 5f) and a sea ice melt season that began nearly 1 month earlier than the 1981-2010 mean in the Kara and Laptev Seas (http: //nsidc.org/arcticseaicenews/2020/08/steep-decline-sputters-out/).

Summer air temperatures were relatively high for the central Arctic Ocean $\left(4^{\circ}-5^{\circ} \mathrm{C}\right.$ above average) and dissipated toward the terrestrial Arctic (Fig. 5.2c). Although warm anomalies over north-central Siberia were not as intense as in winter and spring, the strength of the summertime warm anomaly increased toward the coastal areas and into the Kara and Laptev Seas. The North Atlantic Arctic, including Svalbard and Novaya Zemlya, also remained relatively warm through summer. Despite below-normal air temperatures in the interior of the Greenland ice sheet, aboveaverage, but well below record, ice sheet melt ensued (section $5 e$ ). High-pressure ridging atop the Siberian coast (Fig. 5.3c) steered warm air off the continent, across the Kara and Laptev Seas, and toward the central Arctic, contributing to above-average SST anomalies and near-record sea ice losses during late-summer (see sections $5 \mathrm{c}$ and $5 \mathrm{~d}$ ). 
The Eurasian Arctic warm temperature anomaly continued into autumn, particularly along the coast, highlighted by air temperatures $\sim 4^{\circ} \mathrm{C}$ above normal in the Laptev Sea (Fig. 5.2d). Local temperature anomaly maxima were also found over northern Greenland and the Chukchi Sea, stretching into Chukotka and northern Alaska. Amidst a wavy polar jet stream, ridging and southerly winds atop these areas supported above-average air temperatures (Fig. 5.3d).

An Arctic-midlatitude linkage event also emerged from this meridional jet stream configuration. During November, a wide swath of upper-level high pressure developed over warm northern Eurasia (Fig. 5.4c). As with previous late autumn/early winter linkage cases documented by Overland et al. (2021), the associated ridge continued to build into December across the Ural Mountains and Barents-Kara Seas region, while a trough developed downstream that brought extreme cold air to eastern Asia and the North Pacific (Fig. 5.4d).

Sidebar 5.1: Wildland fires in the high northern latitudes-A. YORK, U. S. BHATT, E. GARGULINSKI, Z. GRABINSKI, P. JAIN, A. SOJA, R. THOMAN, S. VERAVERBEKE, AND R. ZIEL

Despite the low annual temperatures and short growing seasons that characterize high northern latitudes (HNL), wildland fire is the dominant ecological disturbance within the region's boreal forest, the world's largest terrestrial biome. The boreal forest, also known as taiga, is the band of mostly coniferous trees stretching across the area north of the July $13^{\circ} \mathrm{C}$ isotherm in North America and Eurasia. Wildland fires also impact tundra regions bordering the taiga. This sidebar summarizes variability and trends in fire disturbance in HNL and outlines how climate and subseasonal fire weather conditions in HNL influence the extent of area burned.

\section{Variability and trends}

Most area burned in HNL occurs during sporadic episodes of large fire growth, preceded by extended periods of drying and accompanied by anomalously hot and dry conditions (Flannigan et al. 2009). For example, 50\% of the area burned in Alaska from 2002 to 2010 was consumed in just 36 days (Barrett et al. 2016). Significant weather events, including prolonged warm dry weather associated with blocking high-pressure systems (Hayasaka et al. 2016) and convective lightning storms (Veraverbeke et al. 2017), are responsible for much of the variability in HNL fire history. In both Alaska and Canada, lightning-caused fires are responsible for the majority of area burned since at least 1980 when reliable records began (AICC data; Hanes et al. 2019), in part because lightning-ignited fires are more likely to be remote and subject to lower levels of suppression compared to human-caused fires.

Long-term data on burned area have been compiled for Alaska and Canada but are more limited in Eurasia and Arctic tundra regions. These records show considerable interannual variability and that large fire years in the most fire-prone HNL regions are not temporally coincident (York et al. 2020). Figure SB5.1 shows cumulative satellite-derived fire detections across HNL from 2012 to 2020 from both the MODIS (Terra and Aqua) and VIIRS SNPP instruments (Giglio et al. 2018; Schroeder et al. 2014). These data are the best available proxy for burned area in the absence of a current satellite-derived high-latitude burned area product.

Within the Arctic Circle $\left(>66.5^{\circ} \mathrm{N}\right), 2020$ and 2019 stand out as extreme fire years that began unusually early in the season (Fig. SB5.1a). The majority of the fire activity in these years was in the republic of Sakha in northeastern Siberia, where fires burned primarily in montane ecosystems across landscapes underlain by permafrost, with some fires burning only about $11 \mathrm{~km}$ from the Chukchi Sea. The 2020 late winter, early spring, and summer temperature anomalies in this region were remarkable (see section $5 b$ ), while precipitation anomalies were below normal, and snowmelt was the earliest recorded since 1967 (Thoman et al. 2020; section 5f). Satellite imagery suggests that a large number of overwintering fires (Scholten et al. 2021) from 2019 jumpstarted the 2020 fire season in the region (Wheeling 2020). Including lower latitudes in fire detection analysis (Figs. SB5.1b,c) decreases the interannual variability and alters the years of maximum fire detections, with 2019 as a consistently exceptional fire year across HNL.

\section{Climatological influences}

Climate is a dominant control of fire activity on interannual and decadal scales. The relationship between climate and fire is strongly nonlinear in both boreal and tundra ecosystems, with likelihood of fire occurrence within a 30 -year period much higher where mean July temperatures exceed $13.4^{\circ} \mathrm{C}$ (Young et al. 2017). HNL fire regimes appear to be responding 


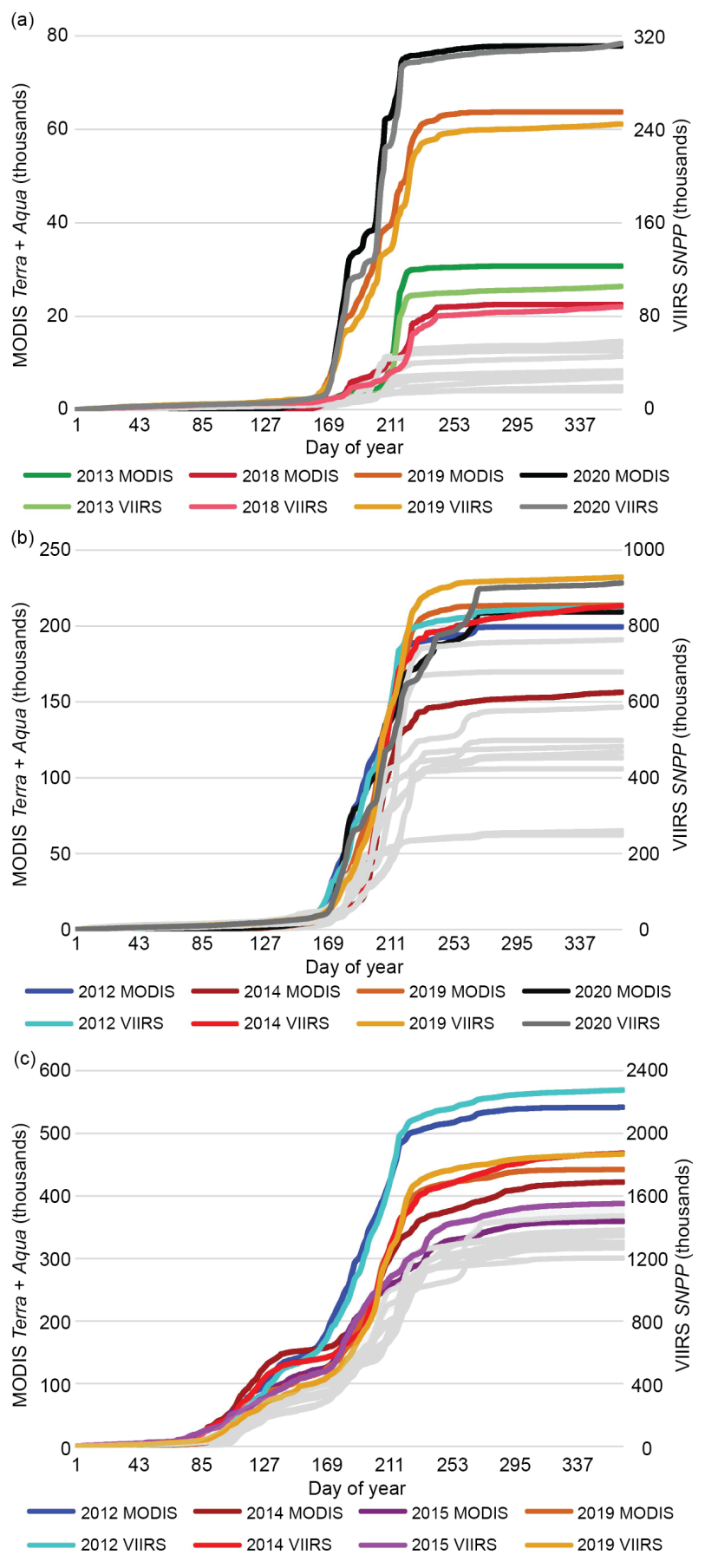

Fig. SB5.1. Cumulative satellite-derived active-fire detections across HNL for 2012-20 from both the 1-km MODIS (Terra and Aqua) and 375-m VIIRS (Suomi NPP) instruments (Giglio et al. 2018; Schroeder et al. 2014) for latitudes (a) $>66.5^{\circ} \mathrm{N}$ (within the Arctic Circle), (b) $>60^{\circ} \mathrm{N}$, and (c) $>50^{\circ} \mathrm{N}$. The 4 years with the highest detections are listed and shown in color within each panel; within each year, colors are distinct. Other years with relatively lower detections are shown in gray. VIIRS detections, shown on the right axis, are consistently an order of magnitude greater than MODIS detections due to the higher resolution of the VIIRS instrument. to environmental changes associated with warming climate (Hanes et al. 2019). Although highly variable, burned area has increased over the past several decades in much, but not all, of boreal North America (Hanes et al. 2019; York et al. 2020, and references therein), and lightning ignitions have increased in the same region (Veraverbeke et al. 2017; Bieniek et al. 2020). Partain et al. (2016) found that anthropogenically-driven climate change increased the likelihood of the extremely dry fuel conditions seen in Alaska in 2015 by $34 \%-60 \%$. South-central Alaska experienced extreme late-season wildfire activity in 2019, accompanied by exceptionally dry summer conditions, observed as the lowest cumulative June-August (ERA5) Standardized Precipitation-Evapotranspiration Index (SPEI) since 1979, as determined by reanalysis (ERA5; Bhatt et al. 2021). A separate analysis of the 2019 Alaska fire season attributed Alaska's extreme fire activity in July to anthropogenic activity, primarily through an increase in anthropogenic ignition and secondarily through climate-induced biomass abundance (Yu et al. 2021).

Reflecting the importance of cumulative drying on fuelbed flammability, the Canadian Forest Fire Danger Rating System (CFFDRS) uses its Buildup Index (BUl; Wotton 2009) as a numerical rating of fuel availability for consumption. The BUI is derived from daily accounting of surface air temperature, relative humidity, and 24-hour rainfall totals. In boreal and arctic systems, BUI reflects the flammability of duff fuels (i.e., accumulated layers of partially decomposed moss and organic material) below the surface (York et al. 2020). As BUI crosses significant thresholds, fires can burn more intensely, spread more aggressively, and pose more problems for suppression.

Figure SB5.2 shows total 2-m air temperature and BUI changes and time series for boreal and tundra regions of Eurasia and North America in June for the 42-year period of record (1979-2020), calculated using ERA5 data (McElhinny et al. 2020). Widespread increases in temperature and BUI in both June and July (data not shown) and on both continents, particularly Eurasia, suggest that conditions are becoming generally more favorable for fire growth, with increases in cumulative drying and flammability likely to result in more intense burning, more fire growth episodes, and greater consumption of fuels. Despite this general trend, considerable interannual variability remains, exemplified by the near-record low June $2020 \mathrm{BUI}$ in North America (Fig. SB5.2d). 
These observations of area burned, BUI, and temperature are consistent with analyses projecting significant increases (up to fourfold) in burned area in HNL ecosystems by the end of the twenty-first century under a range of climate change scenarios (Young et al. 2017; Yue et al. 2015, and references therein). Because specific fire events depend on multiple interacting factors, the resulting changes in HNL fire regimes will vary greatly over space and time. However, all evidence indicates that northern ecosystems are increasingly vulnerable to wildland fire and its impacts.

(Text in this essay was drawn from a longer 2020 Arctic Report Card essay [York et al. 2020].)
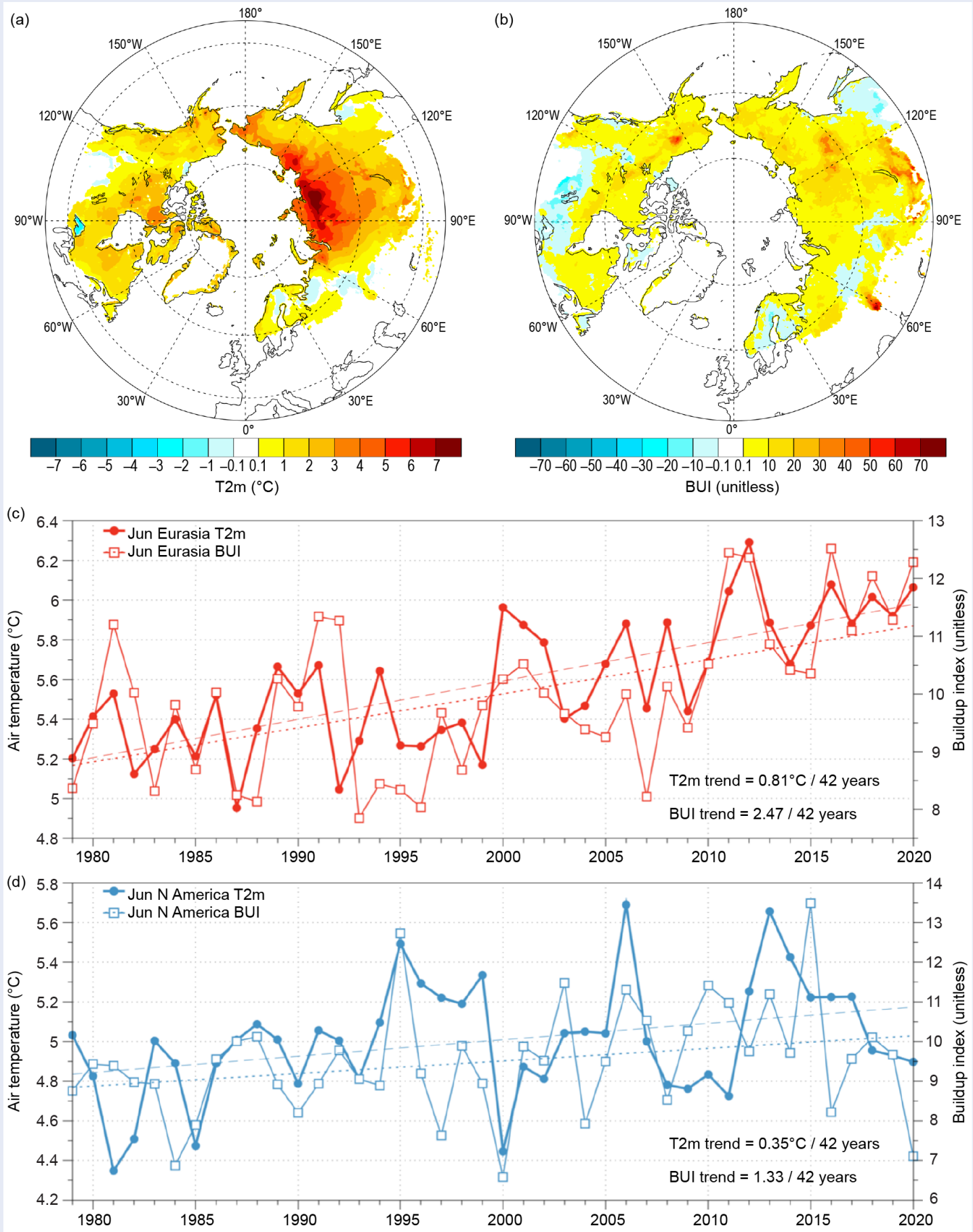

Fig. SB5.2. Change in Jun boreal and tundra (a) 2-m air temperature $\left(T 2 \mathrm{~m}\right.$, in $\left.{ }^{\circ} \mathrm{C}\right)$ and (b) BUI (unitless) from 1979 to 2020 , from ERA5 data. Jun T2m and BUI time series for boreal and tundra areas of (c) Eurasia and (d) North America. Linear-fit trends over 1979-2020 (dashed for T2m and dotted for BUI) are significant for Eurasia at the $99 \%$ confidence level and for North America at the $95 \%$ confidence level using a t-test. 


\section{c. Sea surface temperature-M.-L. Timmermans and Z. Labe}

Summer sea surface temperatures (SSTs) in the Arctic Ocean are driven mainly by the amount of incoming solar radiation absorbed by the sea surface. Solar warming of the Arctic surface ocean is influenced by the distribution of sea ice (with greater warming occurring in ice-free regions), cloud cover, and upper-ocean stratification. Discharge of relatively warm Arctic river waters can provide an additional source of heat to the surface of marginal seas. In the Barents and Chukchi Seas, there is also a contribution to ocean heat by the advection of warm waters from the North Atlantic and North Pacific Oceans, respectively.

Arctic SST is an essential indicator of the role of the ice-albedo feedback mechanism in any given summer sea ice melt season. As the area of sea ice cover decreases, more incoming solar radiation is absorbed by the ocean and, in turn, the warmer ocean melts more sea ice. In addition, higher SSTs are associated with delayed autumn freeze-up and increased ocean heat storage throughout the year. Marine ecosystems are influenced by SSTs, which affect the timing and development of primary and secondary production cycles, as well as available habitat for upper-trophic and temperature-sensitive species. Finally, with respect to carbon cycling, warmer SSTs are associated with reduced ocean uptake of $\mathrm{CO}_{2}$ from the atmosphere, and thus represent another positive feedback loop to a changing climate.

The SST data presented here are a blend of in situ and satellite measurements from August 1982 to August 2020, taken from the monthly mean NOAA Optimum Interpolation (OI) SST Version 2 product (OISSTv2; Reynolds et al. 2002, 2007). Compared to purely in situ temperature measurements, the OISSTv2 product explains about $80 \%$ of the variance, with an overall cold bias via its tendency to underestimate SST by $0.02^{\circ} \mathrm{C}$ (Stroh et al. 2015). The OISSTv2 product uses a linear relationship with sea ice concentration to infer SST, with SST constrained to $-1.8^{\circ} \mathrm{C}$ (the freezing point of seawater with a salinity of $33 \mathrm{~g} \mathrm{~kg}^{-1}$ at the sea surface) where ice concentration is $100 \%$ (Reynolds et al. 2007). Variations in freezing temperature as a result of variations in sea surface salinity (not accounted for in the algorithm) imply that OISSTv2 SSTs under sea ice can be too cool by up to $0.2^{\circ} \mathrm{C}$, with the highest errors in the fresher surface waters of the Canada Basin. August mean SSTs provide the most appropriate representation of Arctic Ocean summer SSTs because they are not affected by the cooling and subsequent sea ice growth that typically takes place in the latter half of September. The period 1982-2010 is used as the climatological reference for the August mean.

August 2020 mean SSTs ranged from $7^{\circ}$ to $10^{\circ} \mathrm{C}$ in the southern Chukchi and Barents Seas to approximately $1^{\circ}$ to $3^{\circ} \mathrm{C}$ in the other Arctic Ocean marginal seas that are ice-free in August (Fig. 5.5a). Mean SSTs in August 2020 were consistent with sustained mean August SST warming trends from 1982 to 2020 over much of the Arctic Ocean, with statistically significant (at the $95 \%$ confidence interval) linear warming trends of up to $+0.1^{\circ} \mathrm{C} \mathrm{yr}^{-1}$ (Fig. 5.5b). Mean August SSTs for the entire Arctic (the Arctic Ocean and marginal seas north of $67^{\circ} \mathrm{N}$ ) exhibit a linear warming trend of 0.03 $\pm 0.01^{\circ} \mathrm{Cyr}^{-1}$. The cooling trend in mean August SSTs in the northern Barents Sea region remains a notable exception (see Timmermans et al. 2020) and remains under study.

August 2020 mean SSTs were around $1^{\circ}-3^{\circ} \mathrm{C}$ warmer than the 1982-2010 August mean over most of the Arctic Ocean's marginal seas (Fig. 5.6a). The largest anomalies were observed in the Laptev and Kara Seas, with values up to $+5.5^{\circ} \mathrm{C}$ (Fig. 5.6a). Conversely, similar to August 2019 conditions, the northern Barents Sea region was marked by anomalously cool SSTs in August 2020 with temperatures up to $-1.5^{\circ} \mathrm{C}$ below the mean (Fig. 5.6), contributing further to the region's long-term cooling trend. Relative to August 2019, August 2020 SSTs were up to $4^{\circ} \mathrm{C}$ cooler in the Chukchi and Beaufort Seas and a few degrees warmer overall in the Kara and Laptev Seas (Fig. 5.6). The strong interannual variability in spatial patterns of SST bear a close relationship to early summer sea ice concentrations (section $5 \mathrm{~d}$ ), with direct solar heating of the exposed surface waters likely driving an active ice-albedo feedback. 

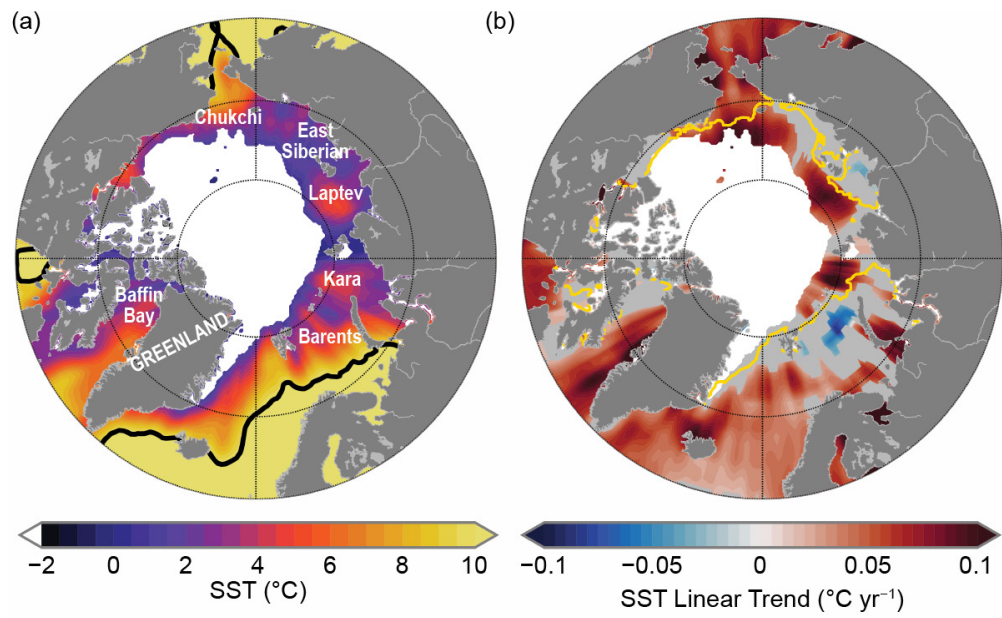

Fig. 5.5. (a) Mean sea surface temperature (SST; ${ }^{\circ} \mathrm{C}$ ) in Aug 2020. White shading is the Aug 2020 mean sea ice extent, and black contours indicate the $10^{\circ} \mathrm{C} \mathrm{SST} \mathrm{isotherm.} \mathrm{(b)} \mathrm{Linear} \mathrm{SST} \mathrm{trend}\left({ }^{\circ} \mathrm{C} \mathrm{yr}^{-1}\right)$ for Aug of each year from 1982 to 2020. The trend is only shown for values that are statistically significant at the $95 \%$ confidence interval; the region is shaded gray otherwise. White shading is the Aug 2020 mean sea ice extent, and the yellow line indicates the median ice edge for Aug 1982-2010. (Sources: SST data are from the NOAA OISSTv2; sea ice extent and ice edge data are from NOAA/NSIDC Climate Data Record of Passive Microwave Sea Ice Concentration, Version 3; Peng et al. 2013; Meier et al. 2017.)

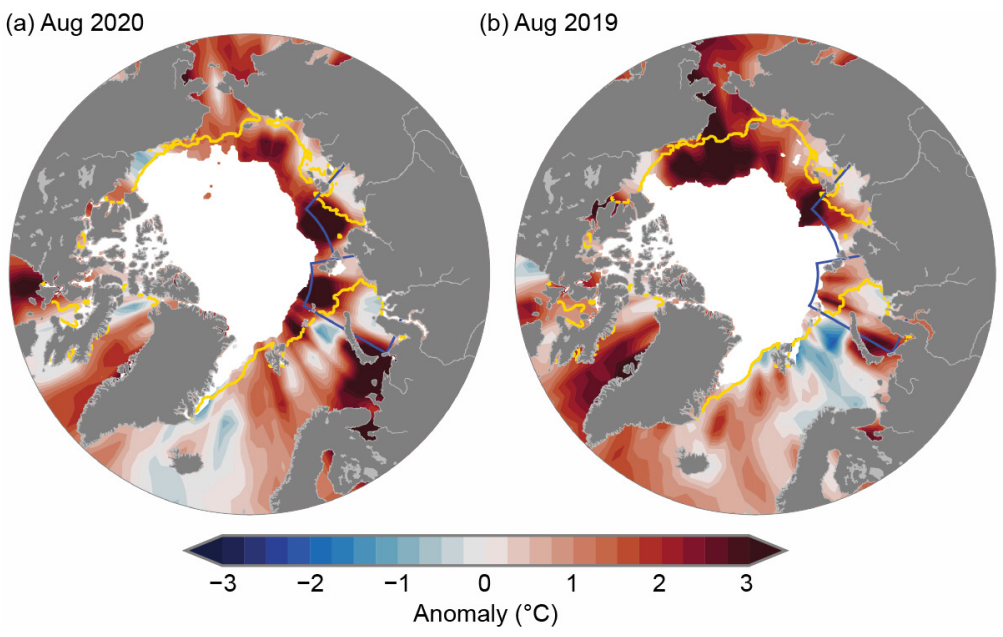

Fig. 5.6. Sea surface temperature (SST) anomalies $\left({ }^{\circ} \mathrm{C}\right.$ ) in (a) Aug 2020 and (b) Aug 2019 relative to the Aug $1982-2010$ mean. The yellow line indicates the median ice edge for Aug 1982-2010 and white shading indicates the mean sea ice extent in (a) Aug 2020 and (b) Aug 2019. The two regions marked by blue boxes indicate the Kara and Laptev Seas and relate to data presented in Fig. 5.7. (Sources: SST data are from the NOAA OISSTv2; sea ice extent and ice-edge data are from NOAA/ NSIDC Climate Data Record of Passive Microwave Sea Ice Concentration, Version 3; Peng et al. 2013; Meier et al. 2017.)

Anomalously warm SSTs in the Laptev and Kara Seas distinguished the August 2020 SST field. Overall, Kara Sea SSTs are becoming warmer in August with a linear warming trend over 1982-2020 of $0.03 \pm 0.01^{\circ} \mathrm{C} \mathrm{yr}^{-1}$ (Fig. 5.7a). Although not statistically significant, Laptev Sea August mean SSTs also appear to be warming, with a linear trend of $0.02 \pm 0.02^{\circ} \mathrm{C} \mathrm{yr}^{-1}$ (Fig. 5.7b). The interplay between regional sea ice cover and solar absorption is evident in the low sea ice extents in August 2020 in these seas (Figs. 5.7c,d). Both regions also saw exceptionally low sea ice extents in July 2020, with Laptev Sea ice extent showing a record minimum for July. A similar pattern of SST anomalies in these regions extended through October 2020. 

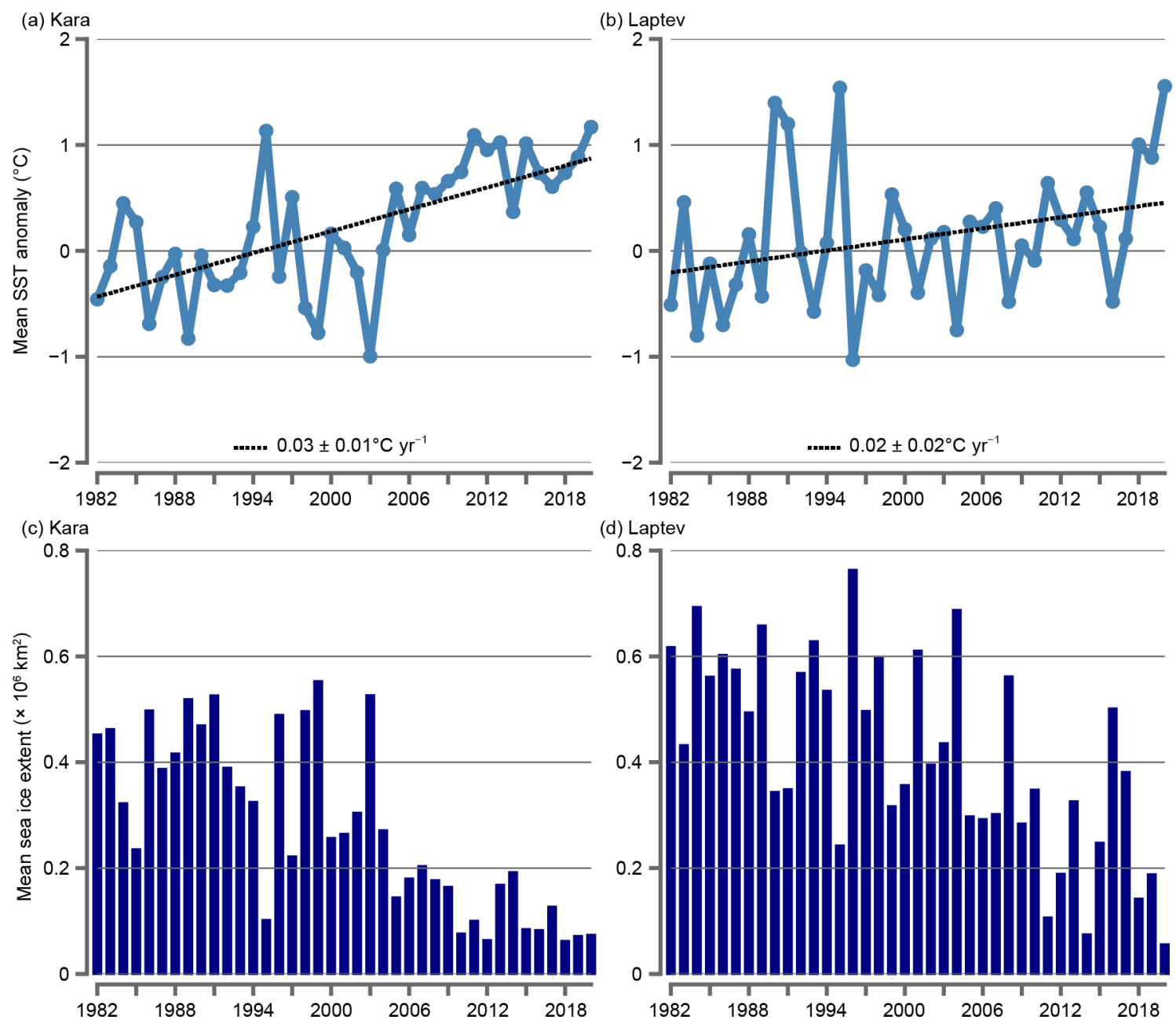

Fig. 5.7. Area-averaged sea surface temperature (SST) anomalies $\left({ }^{\circ} \mathrm{C}\right)$ for Aug of each year $(1982-2020)$ relative to the 1982-2010 Aug mean for the (a) Kara and (b) Laptev Sea regions, shown by blue boxes in Fig. 5.6. The dotted lines show the linear SST anomaly trends over the period shown and numbers in the legends indicate the trends in ${ }^{\circ} \mathrm{C} \mathrm{r}^{-1}$ (with $95 \%$ confidence intervals). Aug sea ice extents calculated over the (c) Kara and (d) Laptev Sea regions. (Sources: SST data are from the NOAA OISSTV2; sea ice extent data are from the NSIDC Sea Ice Index, Version 3 (Fetterer et al. 2017) using a regional mask introduced by Meier et al. 2007.)

d. Sea ice-W. Meier, D. Perovich, S. Farrell, C. Haas, S. Hendricks, L. Kaleschke, A. Petty, M. Tschudi, M. Webster, D. Divine, S. Gerland, O. Pavlova, R. Ricker, X. Tian-Kunze, and K. Wood

\section{1) Sea ice extent}

Sea ice is an important component of the Arctic climate system. It reflects much of the incoming solar energy due to its high albedo, or surface reflectivity, and acts as a physical barrier between the ocean and atmosphere, limiting sensible and latent heat transfer. It also serves as an important habitat for flora and fauna and it is a critical element of Indigenous culture (e.g., Gearheard et al. 2013). The long-term decline of Arctic sea ice extent from the now $>40$-year passive microwave satellite record (1979 to present) has become one of the most iconic indicators of global climate change. Here we use extent values from the National Snow and Ice Data Center (NSIDC) Sea Ice Index (Fetterer et al. 2017). The Sea Ice Index trends and anomalies are generally consistent with other extent products (e.g., the Ocean and Sea Ice Satellite Application Facility Climate Change Initiative [OSI SAF CCI; Lavergne et al. 2019]).

March is the typical month of the maximum annual sea ice extent. In 2020, March extent was 14.79 million $\mathrm{km}^{2}$ (Fig. 5.8a), with the daily annual maximum extent reached on $5 \mathrm{March}$, at 15.05 million $\mathrm{km}^{2}$ - the 11th-lowest daily maximum extent in the satellite record and the highest 

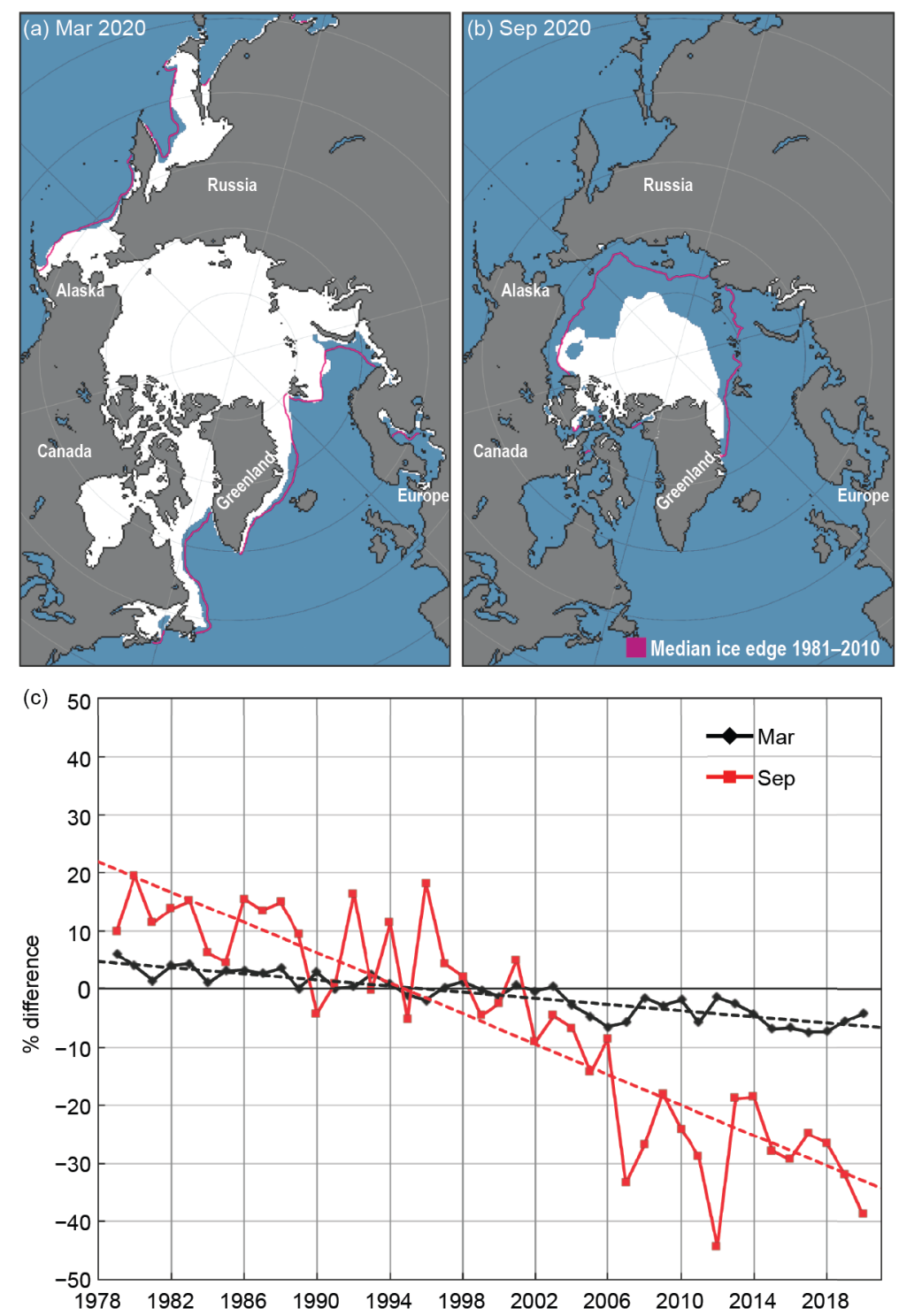

Fig. 5.8. Sea ice extent maps for (a) Mar 2020 and (b) Sep 2020, with ice concentration $>15 \%$ in white; the magenta contour indicates the median extent for 1981-2010. (c) Percent anomaly of Mar (black) and Sep (red) extent for 1979-2020 relative to the 1981-2010 average; the dashed lines indicate the linear trend.

since 2013. The somewhat higher maximum relative to recent years does not account for changes in thickness (discussed below). Also, interannual variability is expected and does not negate the multi-decadal decline in winter ice cover. Overall, March has experienced a significant longterm (1979-2020) trend loss of $-40,400 \mathrm{~km}^{2}$ ice extent per year ( $-2.6 \%$ per decade relative to the 1981-2010 average; Fig. 5.8c).

The summer of 2020 was marked by an early retreat and late freeze-up of sea ice, particularly in the Laptev Sea, leading to daily record lows in the region for much of mid-June through mid-November. As a result, the Northern Sea Route along the Siberian coast was open for about 2.5 months (late July through mid-October), compared to less than a month that was typical in the past. Another notable feature was an unconsolidated ice pack during late summer in the eastern Arctic. This loose ice pack with broken ice floes separated by open water allowed the German icebreaker RV Polarstern to easily reach the North Pole in August as part of the Multidisciplinary Drifting Observatory for the Study of Arctic Climate (MOSAiC).

September is the month when the minimum annual sea ice extent occurs. In 2020, this average monthly ice extent was 3.92 million $\mathrm{km}^{2}$ (Fig. 5.8b), the second lowest monthly extent in the 42-year satellite record. On 15 September, the annual minimum Arctic sea ice extent of 3.74 million $\mathrm{km}^{2}$ was reached; this was also the second lowest on record. The September monthly 
extent has been decreasing at an average rate of $-82,700 \mathrm{~km}^{2}$ per year since $1979(-13.1 \%$ per decade relative to the 1981-2010 average; Fig. 5.8c).

\section{2) Sea ice thickness and volume}

While ice extent provides an easily quantifiable long-term metric of sea ice conditions, the ice thickness and volume provide crucial additional insight into the state of the ice pack. In the past decade, satellite altimetry has provided new estimates of thickness and volume over the entire Arctic basin, beginning with the ESA CryoSat-2 radar altimeter, launched in 2010. The NASA Ice, Cloud, and land Elevation 2 (ICESat-2) laser altimeter, launched in 2018, now provides a second, independent source of thickness estimates.

Because radar altimeter measurements have higher relative errors for thin ice, a product has been developed (Ricker et al. 2017) that combines CryoSat-2 data with estimates of thin ice from the ESA Soil Moisture Ocean Salinity (SMOS) passive microwave radiometer. By combining thickness with sea ice concentration, a seasonal record of sea ice volume can be produced.

The time series of CryoSat-2/SMOS sea ice volume, spanning October 2019 to April 2020, shows that Northern Hemisphere (NH) sea ice volume grew by $\sim 13,400 \mathrm{~km}^{3}$ during the winter 2019/20 season, but it was consistently below the 10-year average through the winter to the beginning of the melt season in April (Figure 5.9a). A spatial map of thickness shows a typical pattern of
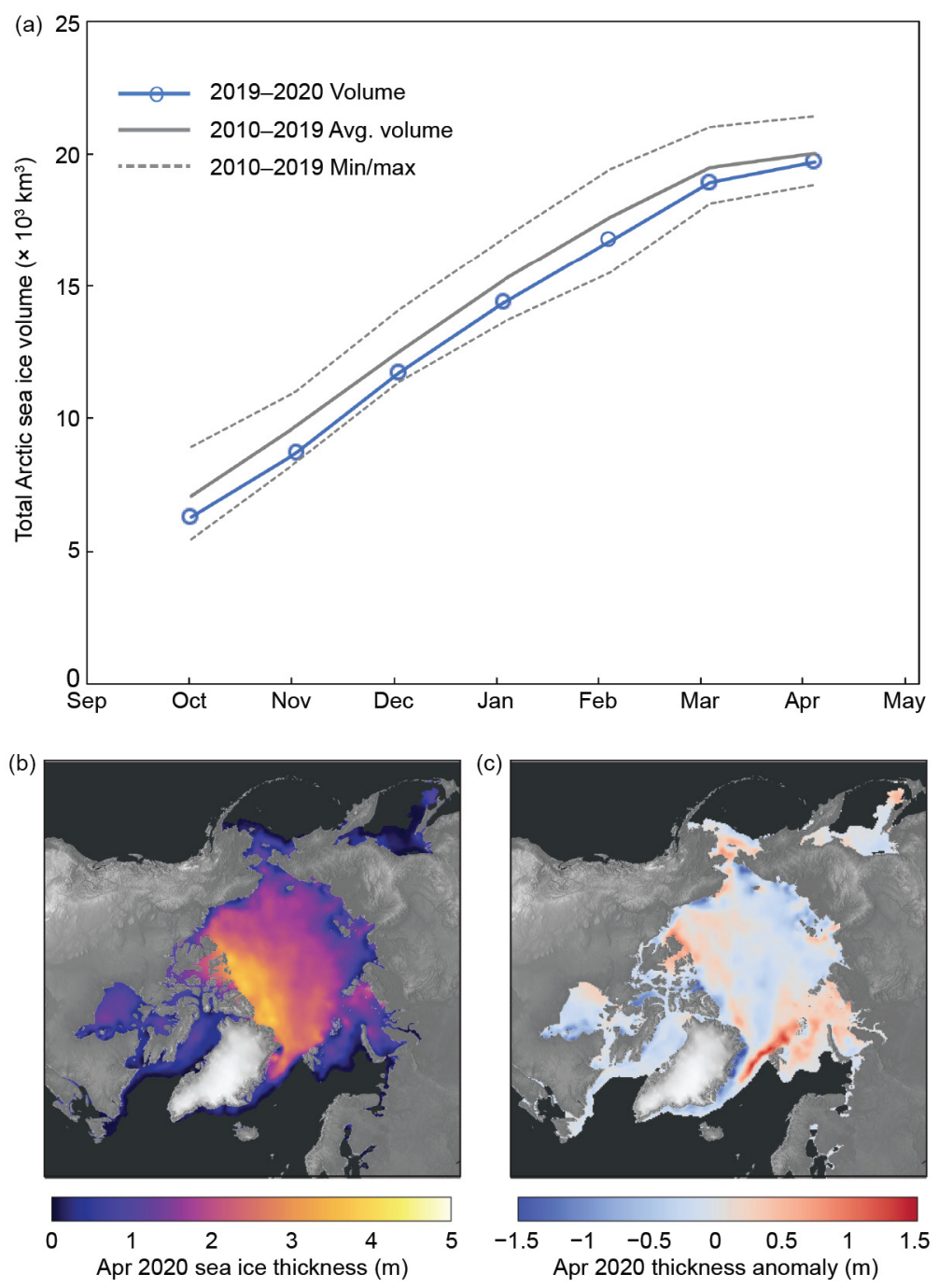

Fig. 5.9. (a) Time series of monthly Northern Hemisphere (NH) sea ice volume $\left(\times 10^{3} \mathrm{~km}^{3}\right)$ from CryoSat-2/SMOS in winter 2019/20, spanning Oct 2019 to Apr 2020 (blue line with blue circles) compared to the 10-year average (solid gray line) for winter 2010/11 through winter 2018/19, and the lowest ( $\min$ ) and highest ( $\max$ ) sea ice volume (dashed gray lines) for the same 10 years; (b) CryoSat-2/SMOS Apr 2020 sea ice thickness (m) and (c) thickness anomaly (m). 
thicker ice toward Greenland and the Canadian Archipelago (Figure 5.9b). The below-average (relative to the 2010-19 average) total sea ice volume in April 2020 was characterized by wide areas of below-average ice thickness in the central Arctic basin and on the Russian continental shelves (Figure 5.9c). However, ice thickness in April 2020 was above average in the Beaufort, Barents, and Greenland Seas and north of Svalbard, likely caused by an increase in southward advection of thicker multiyear sea ice.

The CryoSat-2/SMOS estimates are consistent with sea ice thickness estimates derived from ICESat-2 release 3 freeboards (not shown), updated from Petty et al. (2020) using NESOSIM v1.1 (Petty et al. 2018) snow loading. These thickness estimates within an inner Arctic Ocean domain also indicate a slightly thinner winter ice cover for much of 2019/20 compared to 2018/19, with an April 2020 mean thickness of $2.0 \pm 0.3 \mathrm{~m}$ (compared to $2.1 \pm 0.3 \mathrm{~m}$ in April 2019).

\section{3) Ice age}

The age of sea ice is another key descriptor of the state of the sea ice cover, and older ice tends to be thicker and thus more resilient to changes in short-term atmospheric and oceanic variations compared to younger (thinner) ice. Sea ice age derived from Lagrangian tracking of ice parcels (Tschudi et al. 2019, 2020) indicates a significant loss of older ice types. In the mid1980 s, ice $>3$ years old was the dominant type of ice within the Arctic Ocean region, comprising roughly a third of the ice in March (Fig. 5.10). In March 2020, less than $10 \%$ of the Arctic Ocean ice cover was older than 3 years. The dominant ice type is now first-year ice (0-1 years old), which comprised about 70\% of the March 2020 Arctic Ocean ice cover. The median ice age dropped from 2-3 years old in the mid-1980s to less than 1 year old by 2020 . The total extent of the oldest ice ( $>4$ years old) declined from 2.50 million $\mathrm{km}^{2}$ in March 1985 to 0.34 million $\mathrm{km}^{2}$ in March 2020.

(a) 12-18 Mar 1985
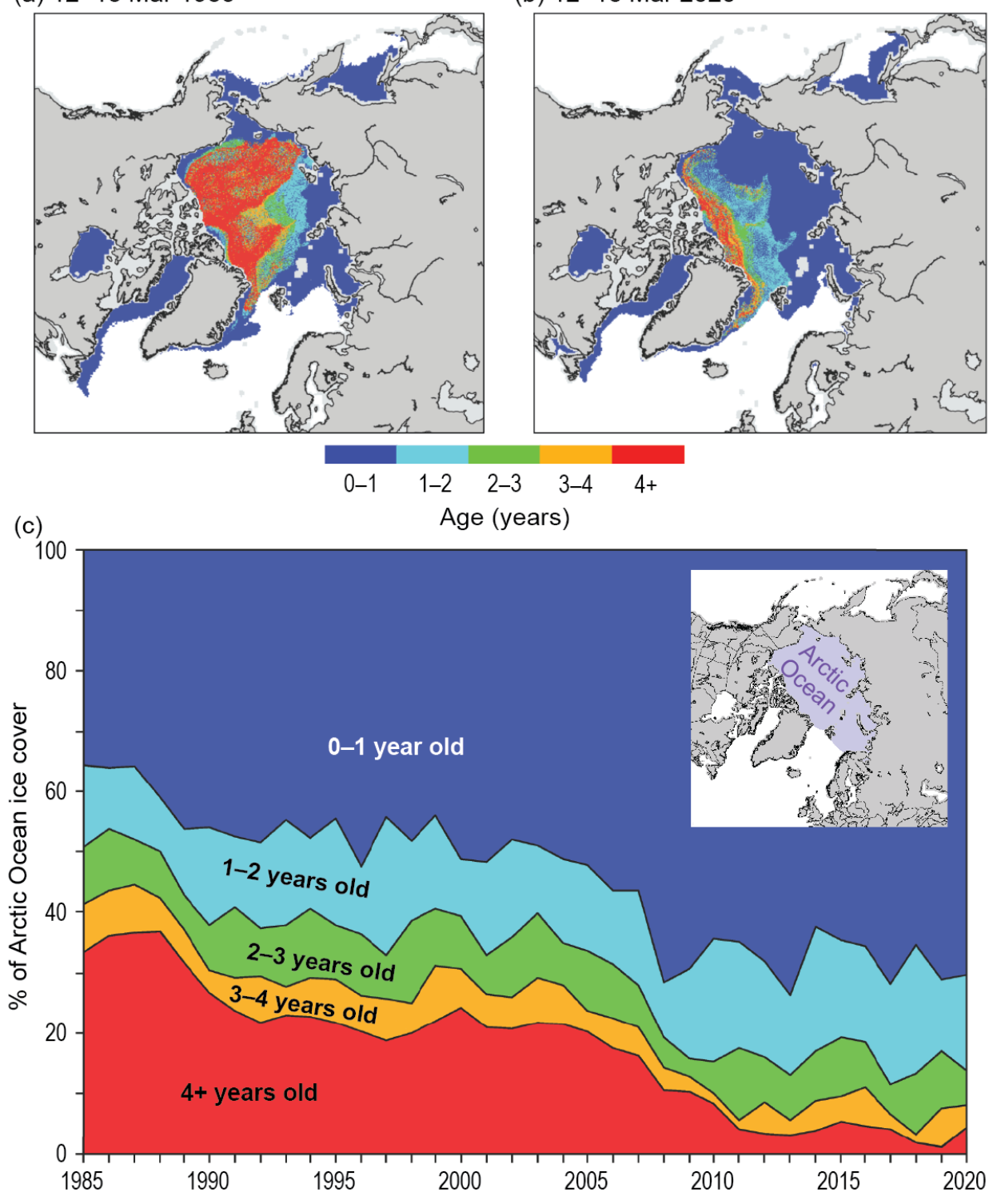

Fig. 5.10. Late winter sea ice age coverage map for the week of (a) 12-18 Mar 1985 and (b) 12-18 Mar 2020. (c) Sea ice age percentage within the Arctic Ocean (purple shaded region in bottom inset) for the week of 12-18 Mar from 1985 to 2020. (Source: Data are from NSIDC and University of Colorado [Tschudi et al. 2019, 2020].) 
e. Greenland ice sheet-T. A. Moon, M. Tedesco, K. D. Mankoff, J. E. Box, J. Cappelen, R. S. Fausto, X. Fettweis, N. J. Korsgaard, B. Loomis, T. Mote, C. H. Reijmer, C. J. P. P. Smeets, D. van As, R. S. W. van de Wal, and Ø. A. Winton The Greenland ice sheet holds an estimated $7.4 \mathrm{~m}$ of potential sea level rise (Morlighem et al. 2017). Following a period of relative stability from the 1970 s to early 1990s, the ice sheet began losing ice at an accelerating rate (Mouginot et al. 2019). The two largest annual mass losses since regular monitoring began in the 1950s occurred in 2012 and 2019, with losses of $-464 \pm 62 \mathrm{Gt}$ and $-532 \pm 58 \mathrm{Gt}$, respectively (Sasgen et al. 2020; estimates including all Greenland glaciers and peripheral ice caps). Total ice loss in 2020 was $-293 \pm 66 \mathrm{Gt}$, slightly above the $2002-19$ average. These annual losses are equivalent to $\sim 1.3 \mathrm{~mm}$ (2012: $-464 \mathrm{Gt}) ; 1.5 \mathrm{~mm}(2019:-532 \mathrm{Gt})$; and $\sim 0.8 \mathrm{~mm}$ (2020: $-293 \mathrm{Gt}$ ) of global mean sea level rise. For comparison, 1993-2018 total global mean sea level rise was $\sim 3.3 \mathrm{~mm} \mathrm{yr}^{-1}$ (Frederikse et al. 2020).

Total annual ice loss reflects the annual cycle of snow accumulation (gain) and ice/snow ablation (loss), known as the ice mass balance. To capture this cycle, Greenland measurements are compiled from September through August. The seasons are autumn (September-November), winter (December-February), spring (March-May) and summer (June-August), and anomalies are relative to the 1981-2010 mean unless noted otherwise. The Greenland ice mass budget is determined by the total of two components: surface mass balance (SMB) - the total annual surface mass change (usually positive) that is particularly linked to atmospheric and ice sheet surface conditions-and dynamic ice loss from the calving of icebergs (solid ice discharge) into the ocean (always negative).

Turning first to SMB, results from the Modèle Atmosphérique Régional (MAR; e.g. Tedesco et al. 2013) using the ECMWF Re-Analysis 5 (ERA5) indicate a SMB anomaly of $-68 \pm 40 \mathrm{Gt} \mathrm{yr}^{-1}$ over September 2019-August 2020 with respect to the 1981-2010 mean of $343 \pm 100 \mathrm{Gt} \mathrm{yr}^{-1}(2020$ anomaly shown in Fig. 5.11a; note that $1 \mathrm{~km}^{3}$ water equivalent is equal to $1 \mathrm{Gt}$ ). Abnormal cyclonic circulation promoted near- to below-average summer air temperatures in the interior and east, while warmer-than-average conditions impacted the southern, northern, and most coastal regions. In situ temperature measurements at 20 Danish Meteorological Institute (DMI) weather stations and eight Programme for Monitoring of the Greenland Ice Sheet (PROMICE) weather station transects were also near- to above-average during autumn 2019 and spring 2020, consistent with concurrent net ablation measurements (Fig. 5.11b; Fausto and van As 2019). Winter 2019/20 temperatures were near to below average at almost all DMI stations and substantially lower than average at Summit Station in the ice sheet interior.

Atmospheric and ice sheet surface conditions influence snow microphysical properties, especially albedo, the fraction of surface reflected sunlight. A high albedo (bright surface) means more sunlight is reflected, while a low albedo (dark surface) leads to greater sunlight absorption. The 2020 overall summer ice-sheet-wide albedo (0.808) was +1.3 standard deviations above the 2000-20 mean (0.791; Fig. 5.12c), with positive and negative regional anomalies (Fig. 5.12a, using 2000-09 reference period; after Box et al. 2017).

Surface melt duration and extent, measured via daily satellite observations from the Special Sensor Microwave Imager/Sounder (SSMIS) passive microwave radiometer (e.g., Mote 2007; Tedesco et al. 2013) also varied regionally. The overall number of melt days in 2020 was greater than the 1981-2010 mean (80\% of June-August days had a melt extent that was greater than the median melt extent for that day; Fig. 5.12d), with regionally varying anomalies (Fig. 5.12b). Though the 2020 maximum daily melt extent (33.8\% of the ice sheet surface) was lower than the mean maximum daily extent (39.8\%), the cumulative summer melt-day extent (summing melt extent across all days) was 28\% higher than the 1981-2010 mean. In synthesis, there were not many days with very large melt extents, but many days that exceeded the average.

Melt duration patterns generally correspond with albedo and surface air temperature anomalies. In 2020, discrepancies between the melt duration (Fig. 5.12b) and SMB anomalies (Fig. 5.11a) 
(a)

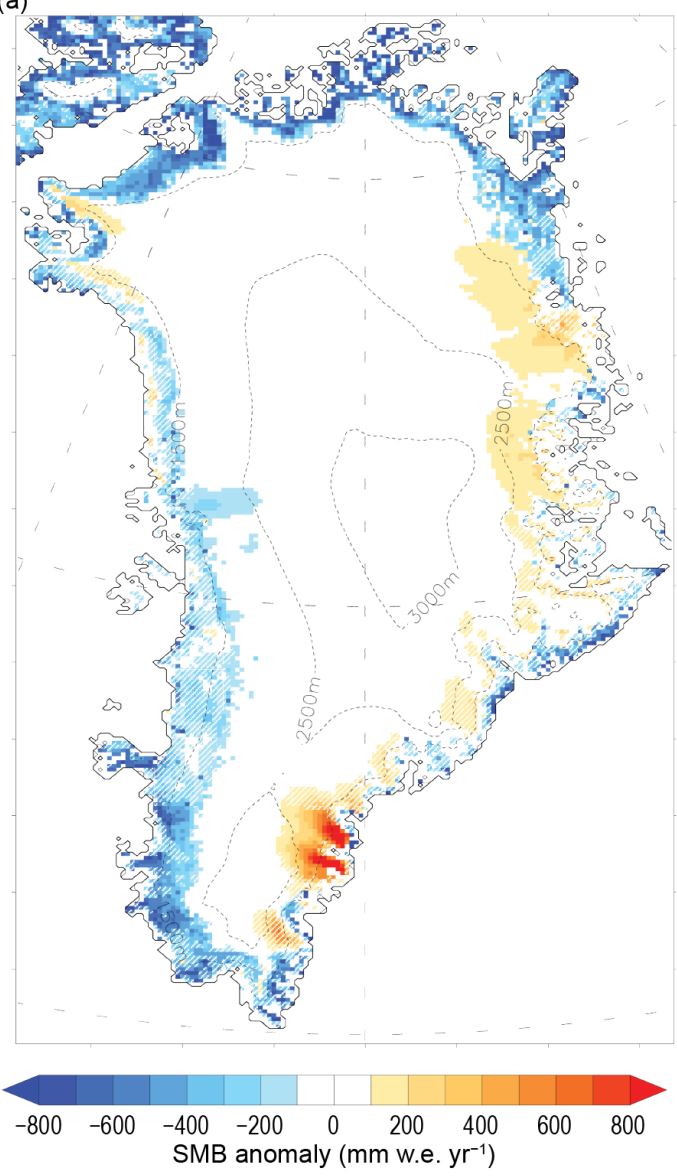

(b)

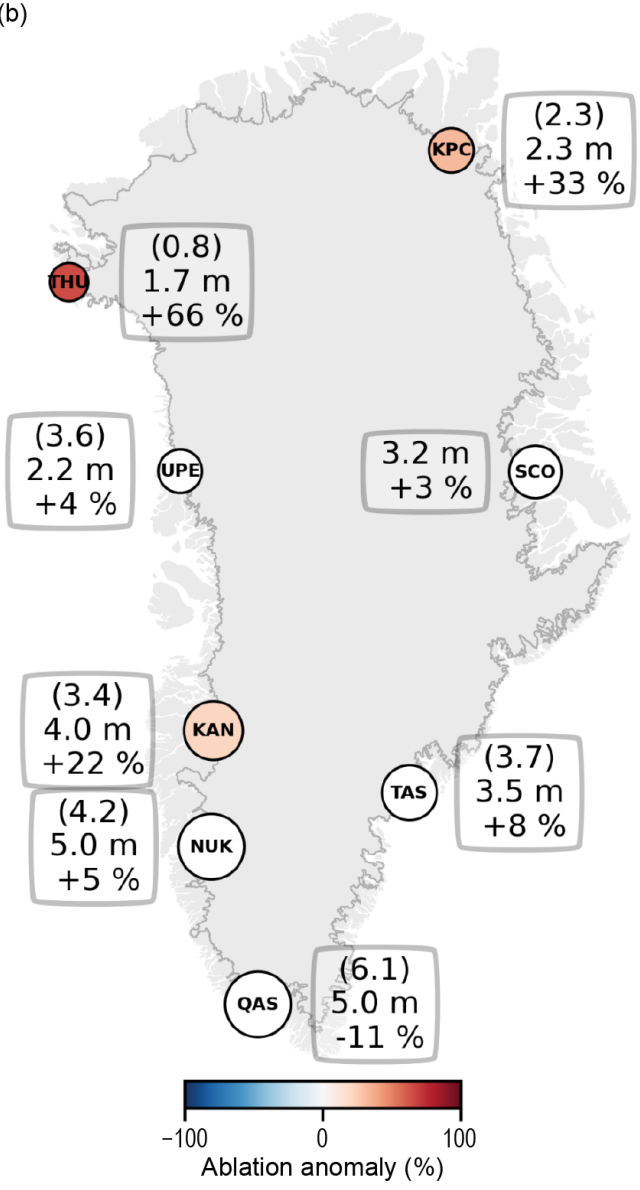

Fig. 5.11. (a) Surface mass balance anomaly for Sep 2019 to Aug 2020 (mm water equivalent $\left.\mathrm{yr}^{-1}\right)$ produced by MAR using reference period 1981-2010. (b) Net ablation for 2020 (covering the end of the 2019 melt season to the end of the 2020 melt season in $\mathrm{m}_{\text {of ice }} \mathrm{yr}^{-1}$ ) from two sources: 1) estimated by MAR (in parentheses at top of inset boxes) and 2) measured via in situ observation at PROMICE weather stations (in parentheses at center of inset box) along the Greenland ice sheet margin. Using PROMICE measurements, circle size is scaled to ice ablation and color indicates anomaly (\%; in parentheses at bottom of inset box), referenced to the 1981-2010 base period following Van As et al. (2016). White circles indicate anomaly values not exceeding methodological and measurement uncertainty.

occurred along the east central margin; summer snowfall increased the surface albedo, while atmospheric conditions such as surface air temperature supported relatively high melt duration.

Turning to solid ice discharge, the 1981-2010 mean total discharge was -460 $\pm 46 \mathrm{Gt} \mathrm{yr}^{-1}$, while mean discharge during 2010-19 was $-487 \pm 49 \mathrm{Gt} \mathrm{yr}^{-1}$ (Fig. 5.13a; Mankoff et al. 2020). Solid ice discharge for September 2019 to August 2020 totaled $-503 \pm 50 \mathrm{Gt} \mathrm{yr}^{-1}$, with the largest contribution from the southeast region (Figs. 5.13a,c). Associated net glacier surface area loss due to glacier front retreat was $-55.4 \mathrm{~km}^{2}$ for 47 Greenland tidewater glaciers selected to provide regional coverage and include major glaciers (Fig. 5.13b), considerably lower than the mean annual loss of $-99.5 \mathrm{~km}^{2}$ for these glaciers since 2002 (Andersen et al. 2019).

Finally, the total mass change of the ice sheet, combining SMB and solid ice discharge, reflects annual contributions to sea level rise. The GRACE (Gravity Recovery and Climate Experiment, 2002-17) and GRACE-FO (Follow On, 2018-present) satellite missions indirectly measure total mass change by detecting gravity anomalies. Over the full span of both missions, the mean rate of mass loss for the Greenland ice sheet is $-268 \pm 14 \mathrm{Gt} \mathrm{yr}^{-1}$ (2-model fit uncertainties reported; Fig. 5.14, GRACE data). GRACE-FO data show that the September 2019 to August 2020 annual mass loss was $-293 \pm 66 \mathrm{Gt}$ (against an average for the period 1980 -2010 of $-75 \pm 145 \mathrm{Gt} \mathrm{yr}^{-1}$ ), equivalent to $\sim 0.8 \mathrm{~mm}$ global sea level rise, and the results align with several other methods (Fig. 5.14). Over the 2018/19 season, a new record annual mass loss of $-532 \pm 58 \mathrm{Gt}$ was observed (Sasgen et al. 


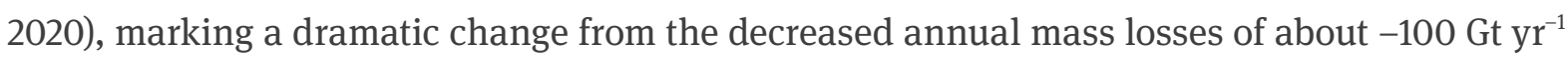
over 2017/18. While mass loss for 2020 exceeds the 2002-19 mean, it is substantially lower than the record 2019 ice loss.

(a)

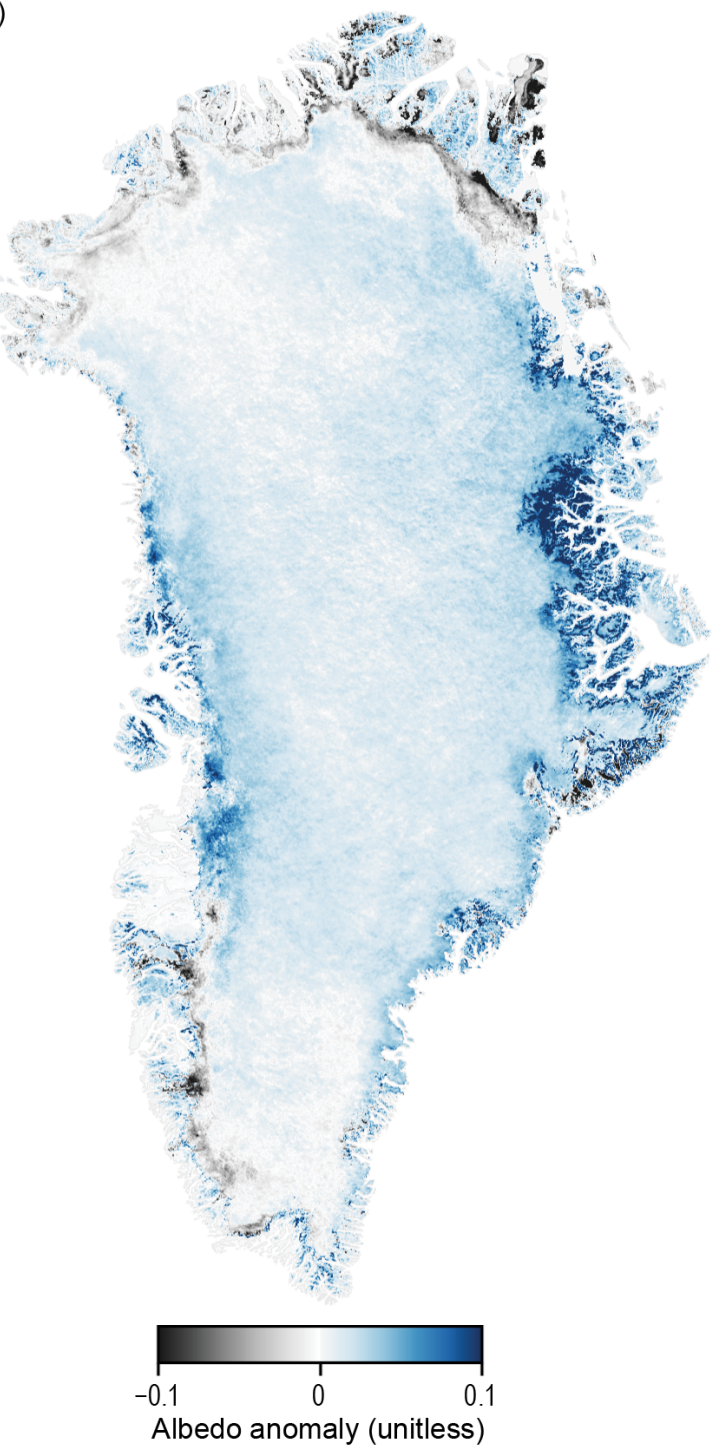

(c)

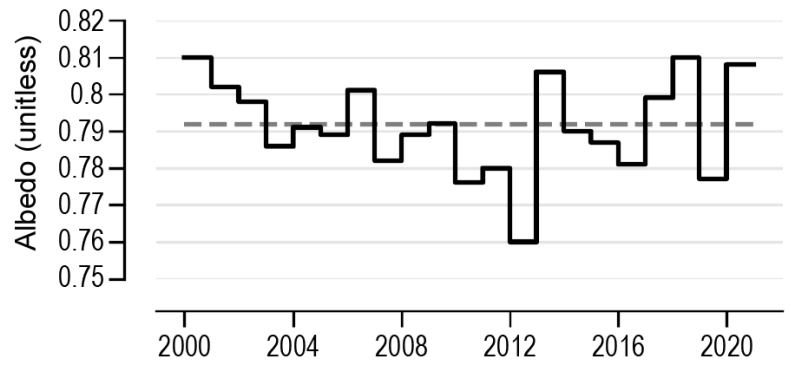

(b)
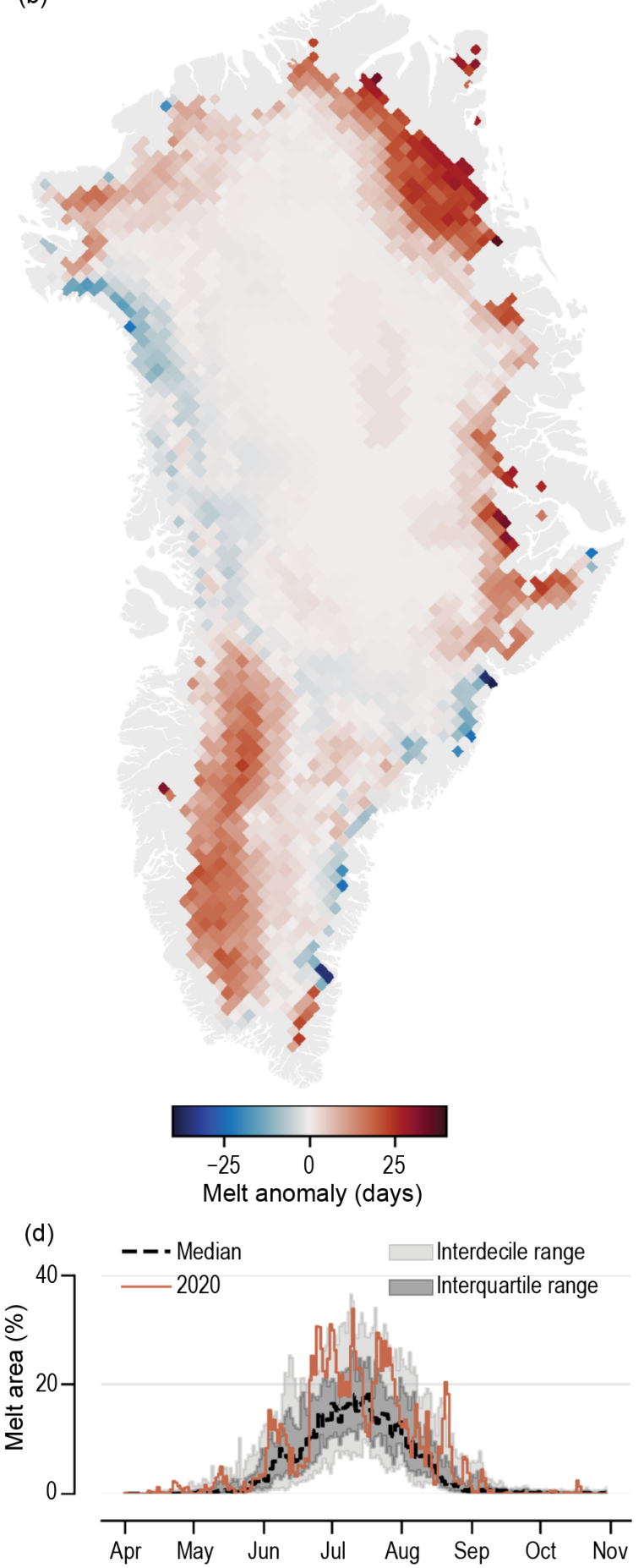

Fig. 5.12. (a) Albedo anomaly for summer 2020, relative to a 2000-09 reference period. (b) Melt anomaly (in number of melting days) for summer 2020 with respect to the 1981-2010 reference period and estimated from spaceborne passive microwave observations. (c) Time series for summer albedo of Greenland ice sheet surface. (d) SSMIS-derived surface melt extent as a percentage of the ice sheet area during 2020 (solid red). 


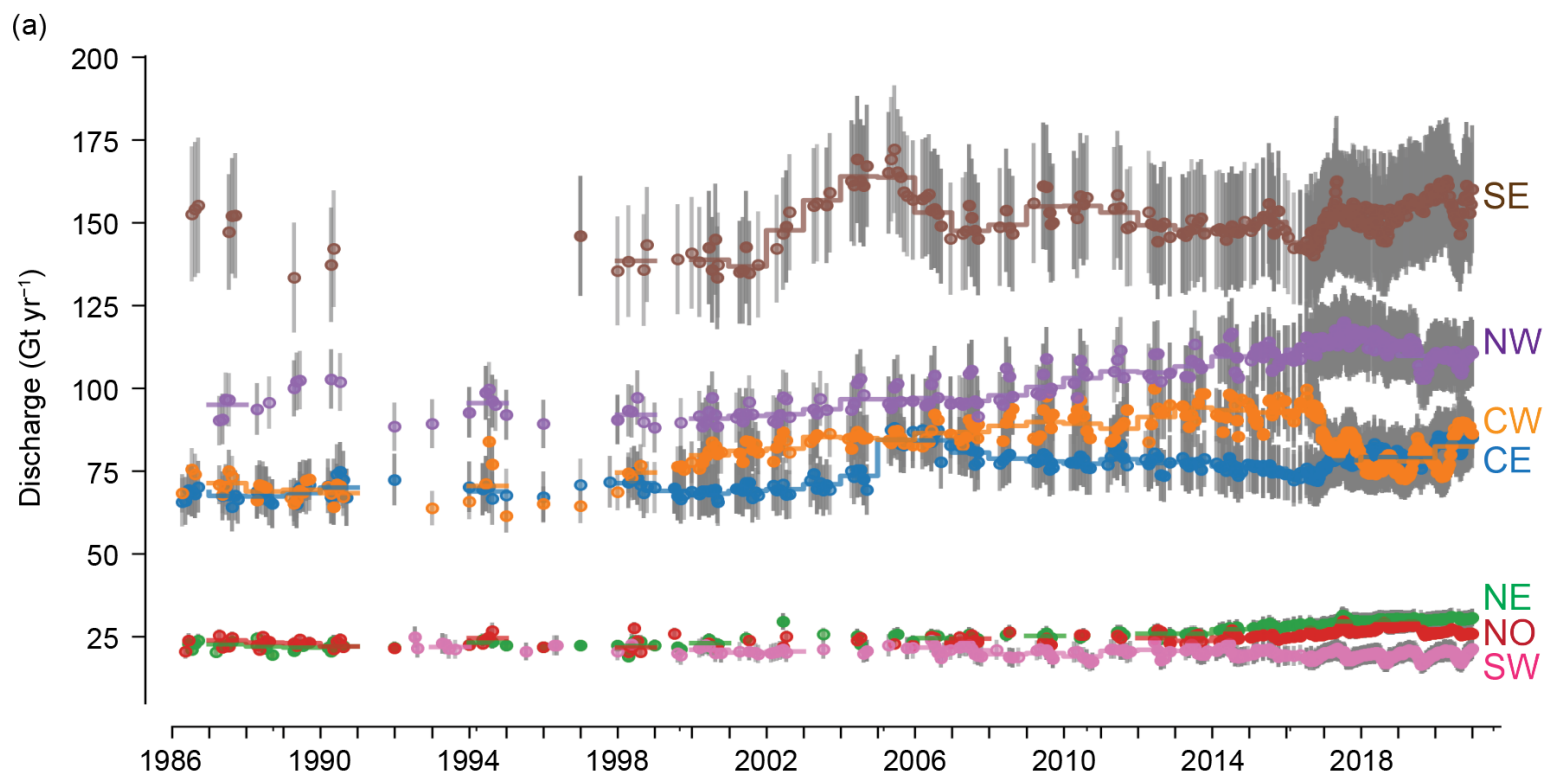

(b)

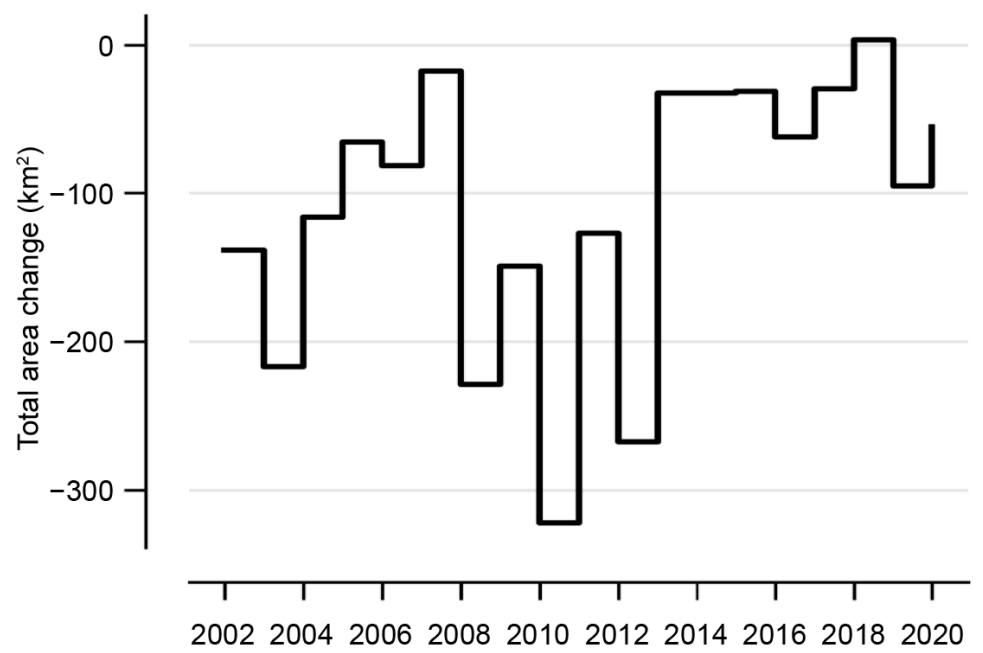

(c)

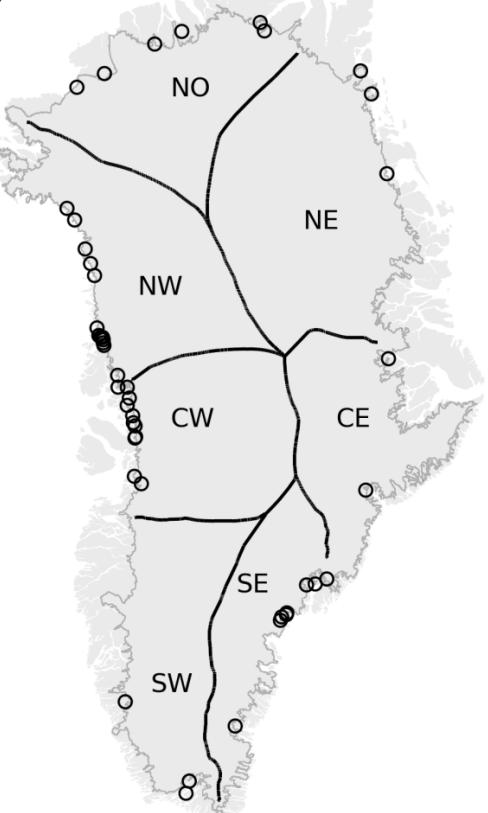

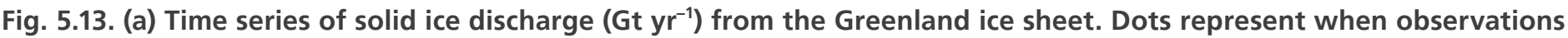
occurred, and gray bars show $\pm 10 \%$ uncertainty range. (b) Total annual area changes $\left(\mathrm{km}^{2}\right)$ at 47 major Greenland tidewater glaciers. (c) Boundaries for regions included in (a): north (NO), northeast (NE), central east (CE), southeast (SE), southwest (SW), central west (CW), and northwest (NW), and sampled glaciers for (b) indicated with open circles. 


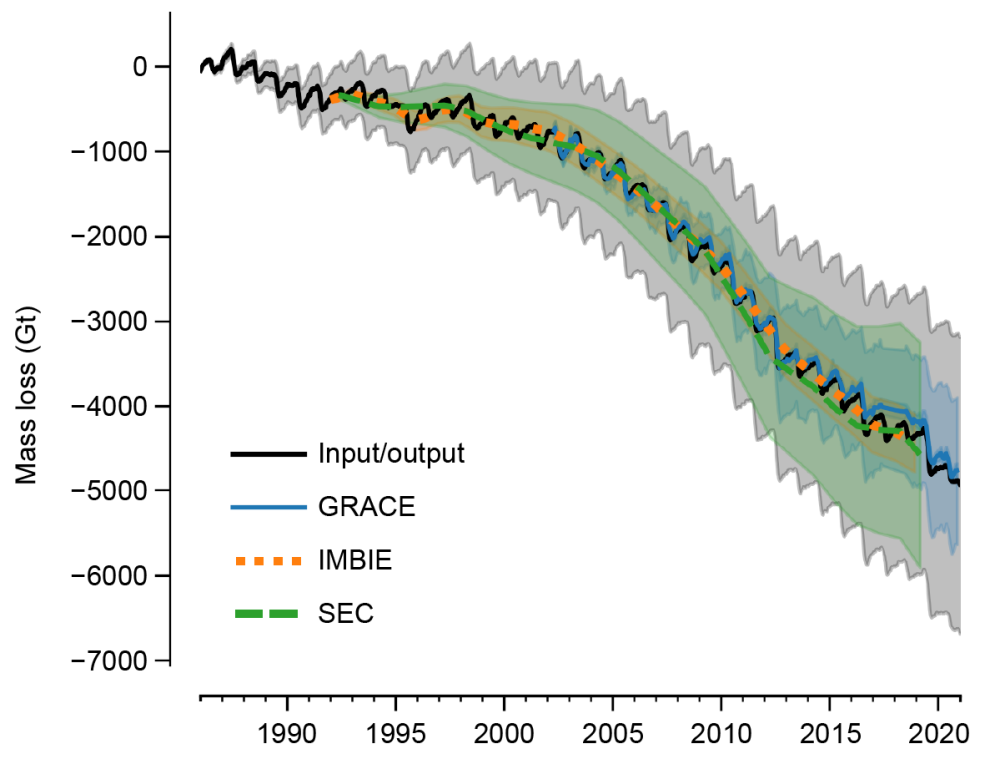

Fig. 5.14. Comparison of results using four total mass balance measurement datasets. IMBIE results are from Shepherd et al. (2020). SEC is from Simonsen et al. (2021, data: 10.11583/DTU.13353062.v1). The input/output method is the mean of MAR, RACMO, and HIRHAM/HARMONIE regional climate models minus discharge from Mankoff (2020, data: https://doi.org/10.22008 /promice/data/ice_discharge/d/v02). GRACE (2002-17) and GRACE-FO (2018-present) data and technical notes are hosted at https://podaac-tools.jpl.nasa.gov/drive/files/allData. GRACE data are scaled by 0.84 to account for peripheral glaciers.

f. Terrestrial snow cover-L. Mudryk, A. Elias Chereque, R. Brown, C. Derksen, K. Luojus, and B. Decharme

Snow covers the Arctic terrestrial surface (areas north of $60^{\circ} \mathrm{N}$ ) for up to 9 months each year and influences the surface energy budget, ground thermal regime, and freshwater budget of the Arctic (Brown et al. 2017). Snow also interacts with vegetation, affects biogeochemical activity, and impacts terrestrial and aquatic ecosystems including migration and access to forage for wildlife (Callaghan et al. 2011). Pan-Arctic monitoring of snow cover extent (SCE), duration, depth, and water equivalent provides a suite of indicators broadly relevant across these physical and ecological systems. All of these indicators exhibit negative trends over long time periods (i.e., 3 decades or more), albeit with varying levels of interannual variability, consistent with a strong response to increasing temperatures (Mudryk et al. 2020a).

SCE anomalies (relative to the 1981-2010 climatology) for spring 2020 were computed separately for the North American and Eurasian terrestrial sectors of the Arctic. Anomalies were derived from the NOAA snow chart climate data record, which extends from 1967 to present (Fig. 5.15). The SCE anomalies over the Eurasian Arctic were well below normal in May (fourth lowest). Additional melt through June associated with a Siberian heat wave resulted in the lowest Eurasian June SCE in the entire 54-year record. North American Arctic spring SCE anomalies were below average in both May and June (eighth and 10th lowest, respectively).

Snow cover duration (SCD) anomalies across the Arctic region for the 2019/20 snow season (Figs. 5.16a,b) were derived from the NOAA daily Interactive Multisensor Snow and Ice Mapping System (IMS) snow cover product. Anomalies in the total number of days with snow cover were computed separately for each half of the snow season: August 2019 to January 2020, referred to as “onset period," and February to July 2020, referred to as “melt period.” The SCD during the onset period (Fig. 5.16a) was close to normal over much of the Arctic, with values reflecting a slightly later start over the eastern Canadian Arctic (Baffin Island and Northern Quebec) and slightly earlier-than-normal onset to the snow season over coastal eastern Siberia and the Scandinavian Peninsula. The marked difference between Arctic and sub-Arctic Europe is linked to atmospheric variability associated with above-average surface temperatures across central Europe. The SCD during the melt period (Fig. 5.16b) over the North American Arctic indicates a combination of late and early melt with more persistent snow occurring in southern Nunavut and early snowmelt 

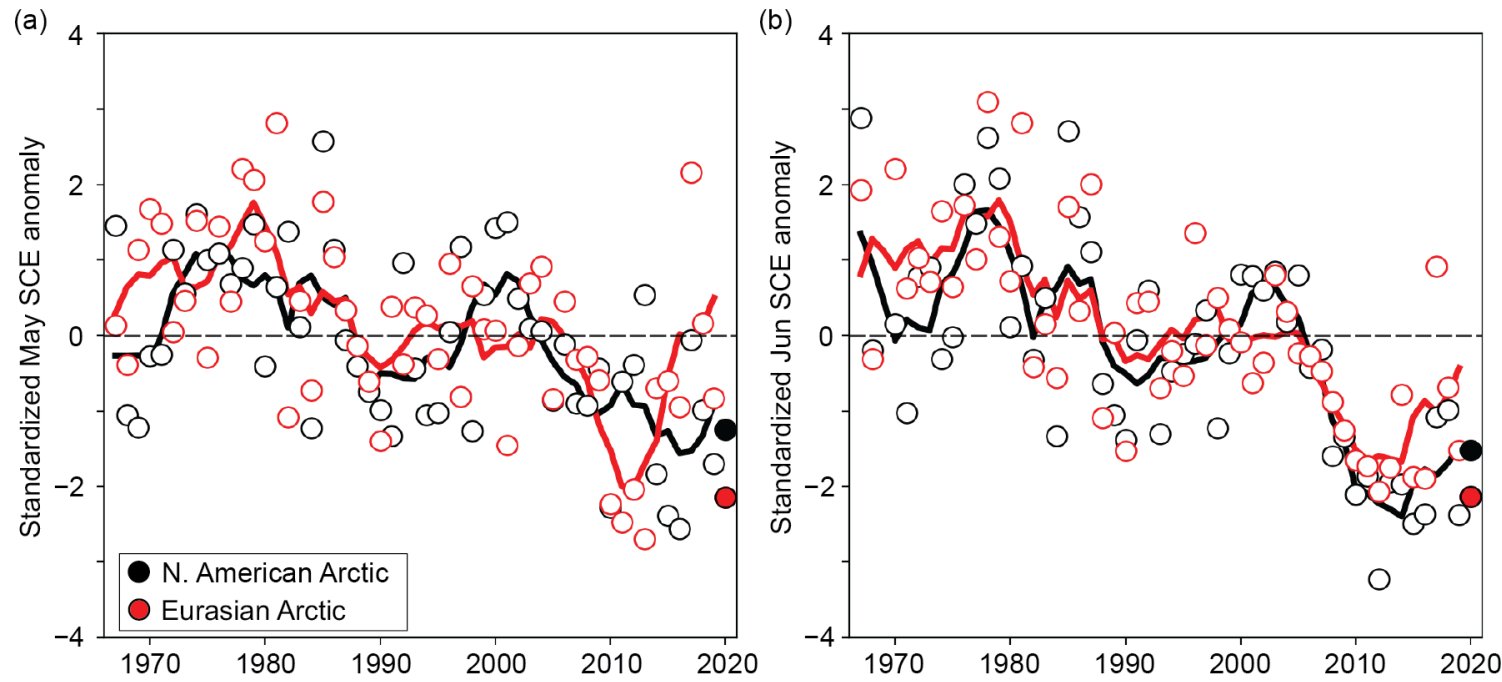

Fig. 5.15. Monthly snow cover exent (SCE) anomalies for Arctic terrestrial areas $\left(>60^{\circ} \mathrm{N}\right)$ for (a) May and (b) Jun from 1967 to 2020. Anomalies are relative to the 1981-2010 average and standardized (each observation differenced from the mean and divided by the standard deviation, and thus unitless). Solid black and red lines depict 5-yr centered running means for North America and Eurasia, respectively, computed with 1968-69 values mirrored before 1967 and 2018-19 values mirrored after 2020. Filled circles are used to highlight 2020 anomalies. (Source: Estilow et al. 2015; Robinson et al. 2012.)

occurring across most of the Canadian Arctic Archipelago and parts of Alaska and Yukon Territory. Over Eurasia, later-than-normal snowmelt occurred over the Scandinavian peninsula, likely due to larger-than-normal snow accumulation (Fig. 5.16c), consistent with an earlier start to the snow season and above-normal winter precipitation. In marked contrast, and despite the larger-than-normal accumulation of snow through March (Fig. 5.16c), springtime temperatures averaging more than $+5^{\circ} \mathrm{C}$ above normal (see section $5 \mathrm{~b}$ ) resulted in complete snowmelt up to a month early across extensive areas of central Siberia.

Snow depth anomalies (Figs. 5.16c,d) were derived from the Canadian Meteorological Centre (CMC) daily gridded global snow depth analysis, which combines air temperature and precipitation analyses with the assimilation of surface snow depth observations. Snow accumulation over the 2019/20 season resulted in above-average March snow depth across the Arctic (Fig. 5.16c). In parts of the North American Arctic, deep snow persisted throughout the spring into June (Fig. 5.16d). Across central Siberia, changes in monthly snow depth from April to June signified strong melt, which led to below-average June snow depths (Fig. 5.16d) and the lowest Eurasian Arctic June snow extent in the full observational record, despite the anomalously deep March snowpack.

Four products were used to generate a multi-dataset snow water equivalent (SWE) anomaly time series (1981-2020) for April (Fig. 5.17): (1) the Modern-Era Retrospective Analysis for Research and Applications version 2 (MERRA-2); (2) a simple temperature index model driven by ERA-interim meteorology described in Brown et al. (2003); (3) the physical snowpack model, Crocus (Brun et al. 2013), also driven by ERA-Interim meteorology; and (4) the European Space Agency GlobSnow product derived through a combination of satellite passive microwave data and climate station observations. Note that Crocus data were not available for 2019 or 2020 and that ERA5 meteorology was used to provide a 2020 SWE estimate from the temperature index model (ERA-interim production ceased in mid 2019). The use of multiple SWE products allows for the determination of inter-product spread through the time series (though the calculated spread may be reduced for 2019/20 owing to the use of three products in place of four). The SWE estimates for April 2020 indicate above-normal snow accumulation over both the Eurasian and North American Arctic, consistent with deeper-than-normal March snow depths shown in Fig. 5.16c. 
In summary, snow accumulation during the 2019/20 winter was above normal across nearly the entire Arctic. Nonetheless, above-average springtime temperatures over central Siberia were extreme enough to drive rapid snowmelt that produced the lowest Eurasian June SCE documented across the 54-year observational record. Springtime anomalies of SCE over North America were more moderate, though still negative, due to a combination of regions with deeper, more persistent snow and regions that experienced early melt.
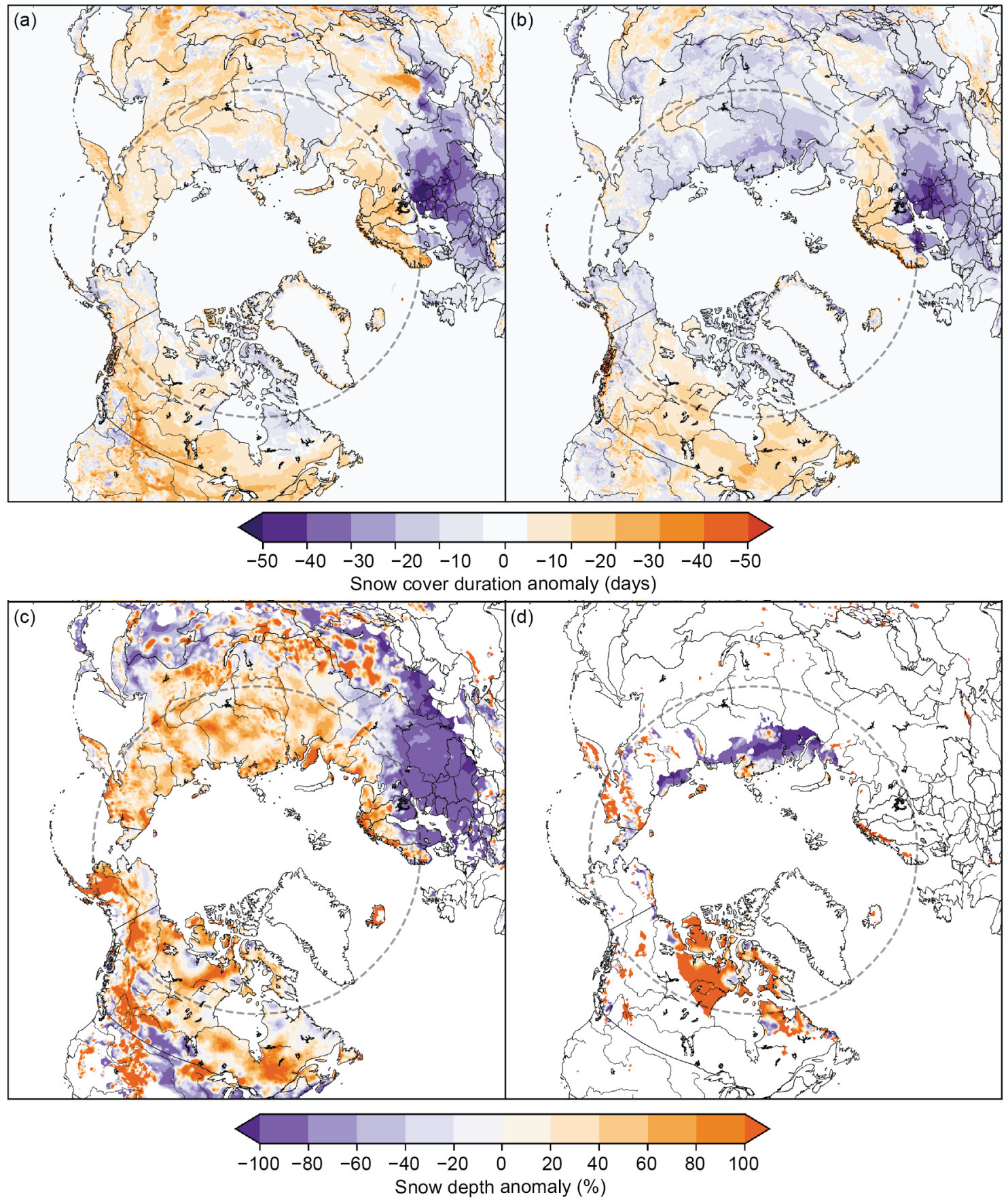

Fig. 5.16. Snow cover duration (SCD) anomalies (days; difference from 1998-2018 mean; purple denotes shorter SCD than average; orange denotes longer SCD than average) across the (a) snow onset period (Aug 2019-Jan 2020) and (b) snowmelt period (Feb-Jul 2020). Snow depth anomalies (\% of the 1999-2018 average; purple denotes shallower snow than average; orange denotes deeper snow than average) in 2020 for (c) Mar and (d) Jun. The latitude $60^{\circ} \mathrm{N}$ is marked by a gray dashed circle; land north of this circle defines Arctic terrestrial areas considered in this study. (Source: [a and b] Helfrich et al. 2007; U.S. National Ice Center 2008. [c] and [d] Brasnett 1999; Brown and Brasnett 2010.) 


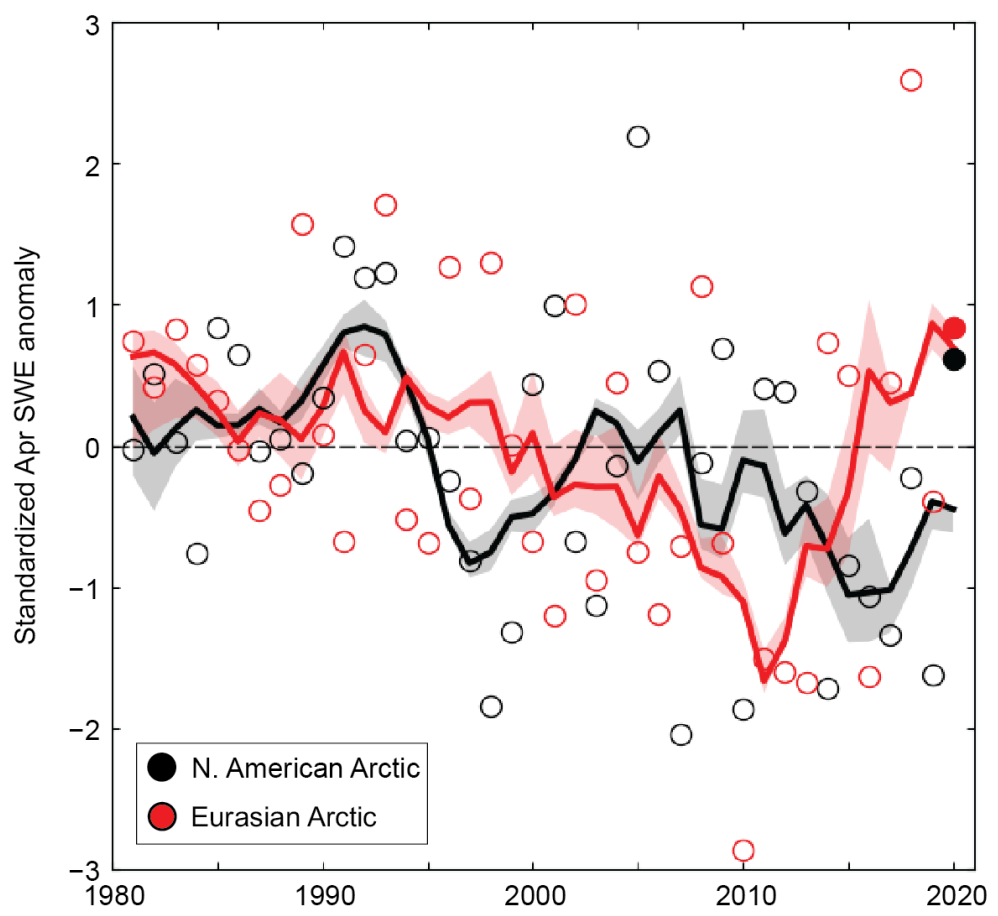

Fig. 5.17. Mean April snow water equivalent (SWE) anomalies for Arctic terrestrial areas calculated for North American (black) and Eurasian (red) sectors of the Arctic. Anomalies are relative to the 1981-2010 average and standardized (each observation differenced from the mean and divided by the standard deviation, and thus unitless). Filled circles are used to highlight 2020 anomalies. Solid black and red lines depict 5-year centered running means for North America and Eurasia, respectively, computed with 1982-83 values mirrored before 1981 and 2018-19 values mirrored after 2020. Spread among the running means for individual datasets is shown in shading. (Sources: MERRA2: Gelaro et al. 2017; GMAO 2015; temperature index model: Brown et al. 2003; Crocus: Brun et al. 2013; GlobSnow: Takala et al. 2011; www.globsnow.info.)

g. River discharge-R. M. Holmes, A. I. Shiklomanov, A. Suslova, M. Tretiakov, J. W. McClelland, L. Scott, R. G. M. Spencer, and S. E. Tank

The Arctic Ocean makes up approximately $1 \%$ of the global ocean by volume but receives more than $10 \%$ of global riverine discharge (McClelland et al. 2012). Consequently, terrestrial influences via river inputs are more pronounced in the Arctic Ocean than in other ocean basins. The rapid environmental change occurring in the Arctic is altering land-ocean interactions, which is also impacting coastal and ocean physics, chemistry, and biology. Because rivers naturally integrate the processes that are occurring throughout their watersheds, trends in the discharge and chemistry of Arctic rivers can also signal widespread terrestrial change including permafrost thaw and the amount or seasonality of precipitation (Rawlins et al. 2010; Holmes et al. 2013).

A long-term increase in Arctic river discharge has been well documented by time series data dating to the 1930s, providing compelling evidence of intensification of the Arctic hydrologic cycle (Peterson et al. 2002; McClelland et al. 2006). While there is still some uncertainty about what is driving this trend, increased atmospheric moisture transport may contribute to precipitation increases in some seasons (Zhang et al. 2013; Vihma et al. 2016). For example, there is a tendency toward increasing snowfall during autumn and early winter in western Siberia (Wegmann et al. 2015) and in the Canadian Arctic (Kopec et al. 2016). The changes in winter precipitation and correspondingly in snow accumulation can partly explain increases in spring river flows, which are mainly due to snowmelt (Shiklomanov et al. 2021). However, aggregated over the pan-Arctic and large river basins, annual precipitation, which is typically the most important water balance component for runoff generation, does not show a large enough change to support the observed increasing trend in annual river discharge (Shiklomanov et al. 2021).

River discharge was last included in the 2018 State of the Climate report. In the present report, river discharge values for 2020 and 2019 are presented to directly compare recent behavior in the 
eight largest Arctic rivers. River data used in this analysis are available through the Arctic Great Rivers Observatory (arcticgreatrivers.org). Six of the rivers lie in Eurasia and two are in North America. Collectively, the watersheds of these eight rivers cover approximately $70 \%$ of pan-Arctic drainage area and account for the majority of river water inputs to the Arctic Ocean (Fig. 5.18). Discharge measurements for the six Russian rivers began in 1936, whereas discharge measurements did not begin until 1973 for the Mackenzie River and 1976 for the Yukon River in North America. These time series are used to establish a reference period (1981-2010) to compare and contextualize recent observations. Years are presented as "water years," 1 October-30 September, to more closely align with the annual cycle of hydrologic processes such that precipitation and runoff occur during the same time period. Thus, water year 2020 covers the period 1 October 2019 through 30 September 2020.

In 2020, the combined discharge of the eight largest Arctic rivers was $2625 \mathrm{~km}^{3}$, which is $277 \mathrm{~km}^{3}$ ( 12\%) greater than the 1981-2010 average (Table 5.1). Discharge from the two North American rivers combined was $\sim 25 \%$ greater than their average, while discharge from the six Eurasian rivers combined was $\sim 8 \%$ greater. Overall, $44 \%$ of the increase above the reference period for the eight rivers came from the two North American rivers, with the Mackenzie River being the largest contributor.

Fig. 5.18. Watersheds of the eight largest Arctic rivers that are featured in this analysis. Collectively, these rivers cover approximately $70 \%$ of the 16.8 million $\mathrm{km}^{2}$ pan-Arctic watershed (indicated by the red boundary line). The red dots show the location of the discharge monitoring stations.

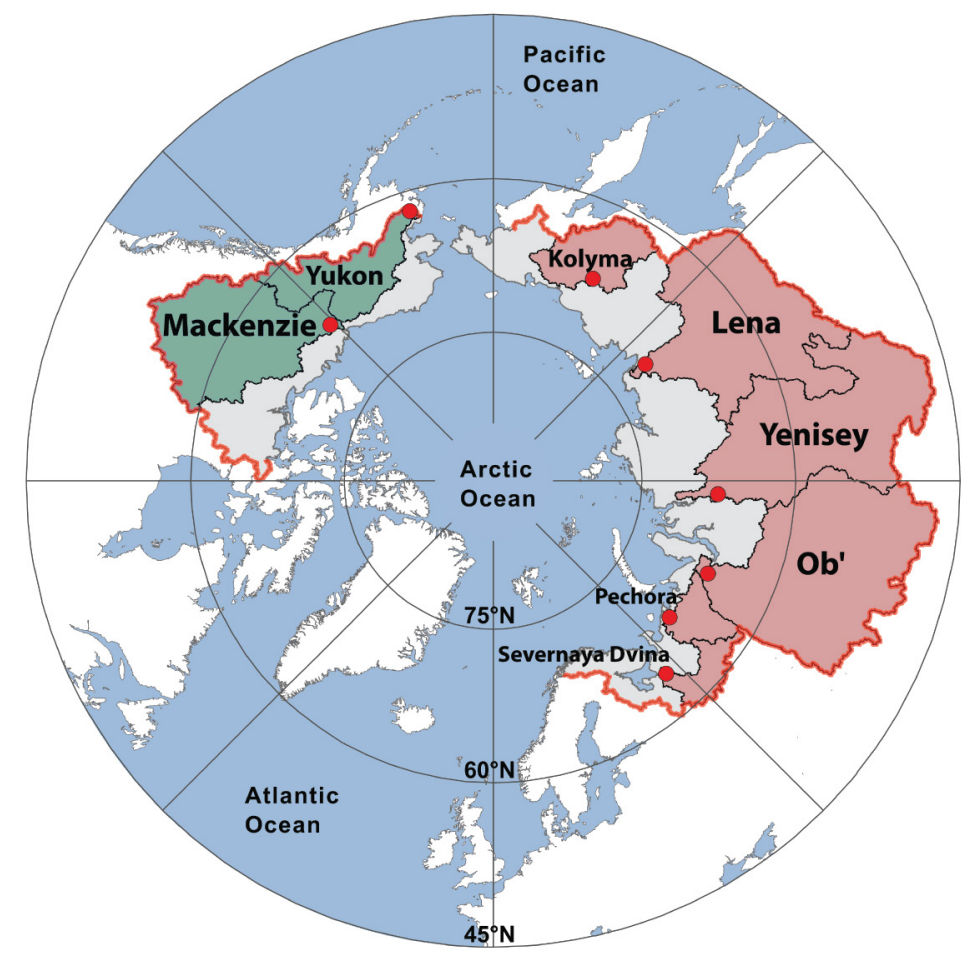

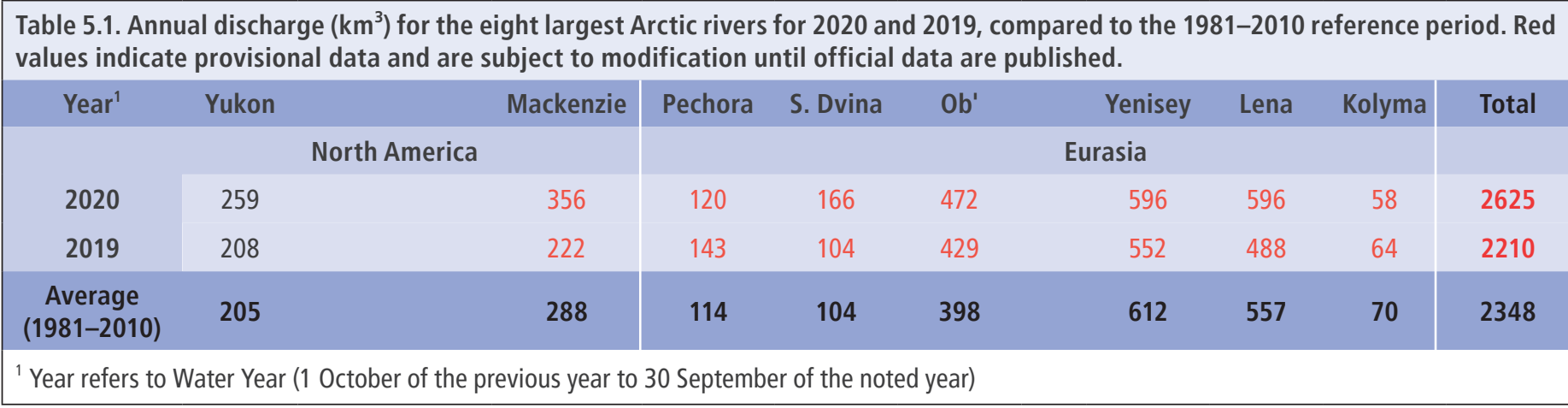


High May-September discharge was largely responsible for the high annual discharge for the North American rivers in 2020 (Fig. 5.19). This can be explained by high snow accumulation and spring flood volume due to record high precipitation in February-April in the Mackenzie River basin and the wettest summer since 1985 based on analysis of precipitation aggregated over the Mackenzie and Yukon watersheds (Hersbach et al. 2020). For the Eurasian rivers, extraordinarily high May discharge (+3.1 std. dev. above average) was followed by extraordinarily low June discharge (-2.3 std. dev. below average; Fig. 5.19). The pattern observed for the Eurasian rivers is consistent with the observed high terrestrial snow cover and snow water equivalent during winter 2019/20, followed by a remarkably warm spring in 2020 (see sections 5b and 5f). This led to an early snowmelt, shifting more of the runoff period from June to May.

In contrast to 2020, 2019 was a relatively low-discharge year. The combined discharge of the eight largest Arctic rivers was $2210 \mathrm{~km}^{3}$, which is $138 \mathrm{~km}^{3}(\sim 6 \%)$ less than the 1981-2010 average (Table 5.1). Discharge from the two North American rivers and the six Eurasian rivers was $\sim 13 \%$ and $\sim 4 \%$ less than average, respectively. Overall, $46 \%$ of the decrease below average came from the two North American rivers, with Mackenzie River discharge being well-below average and the Yukon River being slightly above. The remaining 54\% of the decrease came from the six Eurasian rivers, with the Yenisey and Lena being the largest contributors. Relatively low 2019 Arctic river discharge is consistent with the observations of below-average snow water equivalent in April 2019 in both the Eurasian and North American Arctic (Mudryk et al. 2020b).

The 85-year time series available for the Eurasian Arctic rivers demonstrates an increase in their combined discharge. The positive linear trend across this entire time series indicates that the average annual discharge of Eurasian Arctic rivers is increasing by $2.5 \mathrm{~km}^{3}$ per year. When data are considered from 1976 through 2020 (the length of the period of record for North American rivers), the average annual increase in discharge is $4.4 \mathrm{~km}^{3}$ per year (Fig. 5.20). For the North American Arctic rivers, the average increase over the period of record is $1.0 \mathrm{~km}^{3}$ per year. These observations indicate that Arctic river discharge continues to trend upward, providing powerful evidence for the intensification of the Arctic hydrologic cycle.
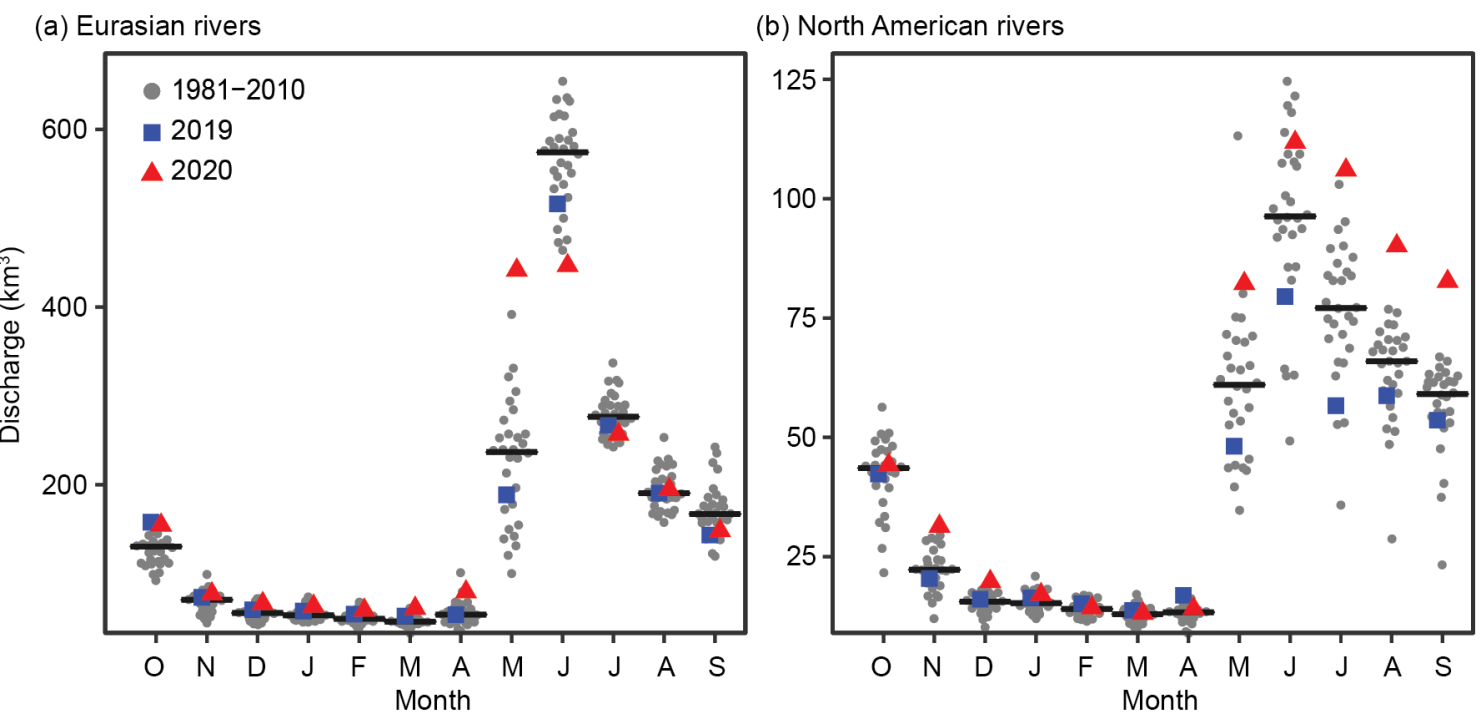

Fig. 5.19. Monthly discharge $\left(\mathrm{km}^{3}\right)$ in (a) Eurasian and (b) North American rivers for 2020 and 2019 compared to monthly discharge throughout the 1981-2010 reference period. The black bars indicate the average monthly discharge during the reference period. 


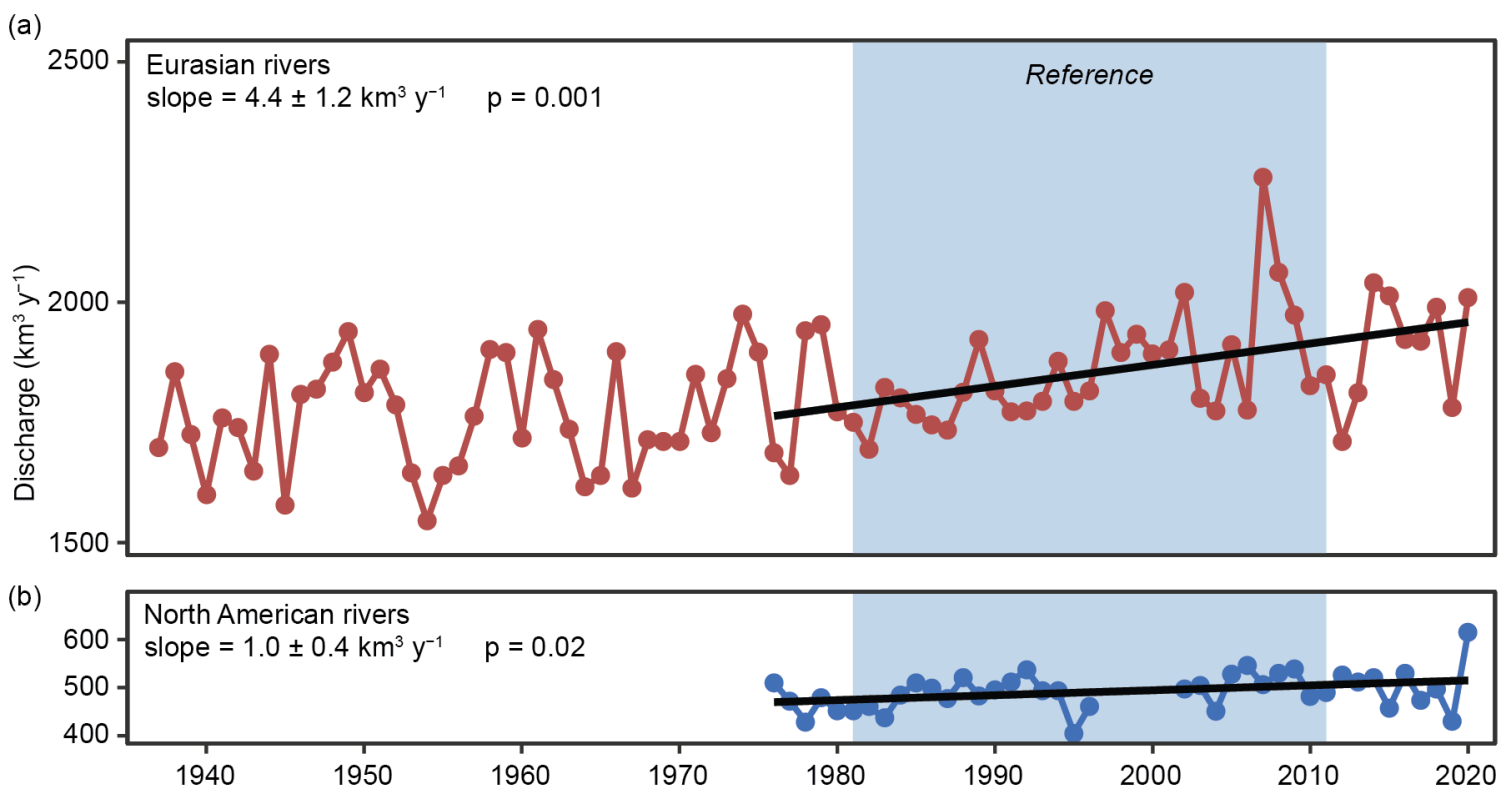

Fig. 5.20. Long-term trends in annual discharge $\left(\mathrm{km}^{3} \mathrm{yr}^{-1}\right)$ for (a) Eurasian and (b) North American Arctic rivers. Gaps in the North American rivers time series span from 1996 through 2001 due to missing Yukon data from 1996 to 2001 and missing Mackenzie measurements in 1997 and 1998. Reported slopes are for the period 1976-2020. Note the different scales for the (a) Eurasian and (b) North American river discharge.

h. Permafrost-S. L. Smith, V. E. Romanovsky, K. Isaksen, K. E. Nyland, A. L. Kholodov, N. I. Shiklomanov, D. A. Streletskiy, L. M. Farquharson, D. S. Drozdov, G. V. Malkova, and H. H. Christiansen

Permafrost refers to Earth materials (e.g., bedrock, mineral soil, organic matter) that remain at or below $0^{\circ} \mathrm{C}$ for 2 years or longer and underlies extensive regions of the high-latitude landscape (Brown et al. 1997). Overlying the permafrost is the active layer, which thaws and refreezes annually. Permafrost, especially where it contains large volumes of ice, can play a critical role in the stability of Arctic landscapes. Warming of permafrost, active layer thickening, and ground ice melt cause changes in surface topography, hydrology, and landscape stability, thus having implications for the integrity of the Arctic infrastructure and ecosystems (Romanovsky et al. 2017; Bjella 2019). Changes in permafrost conditions can also affect the rate of release of carbon dioxide and methane to the atmosphere, with the potential to accelerate global warming (Schuur 2020).

Permafrost conditions respond to shifts in the surface energy balance through a combination of interrelated changes in ground temperature and active layer thickness (ALT). Ground temperatures fluctuate seasonally near the surface, while below the depth of seasonal temperature variation, ground temperature reflects longer-term changes in climate. Long-term changes in permafrost temperatures are driven by changes in air temperature (Romanovsky et al. 2017); however, permafrost temperature trends show local variability due to other important influences such as snow cover, vegetation characteristics, and soil moisture. Monitoring sites across the Arctic (Fig. 5.21) have been recording ground temperature in the upper $30 \mathrm{~m}$ for up to 5 decades, providing critical data on changes in permafrost stability. Observed changes in ALT relate to shorter-term (year-toyear) fluctuations in climate and are especially sensitive to changes in summer air temperature and precipitation.

Travel restrictions in 2020 due to COVID-19 limited data collection in some regions. For boreholes that have data loggers, the lack of site visits may only delay data acquisition with little impact on record continuity. For data collected manually, including ALT, there is a loss of data for 2020. 


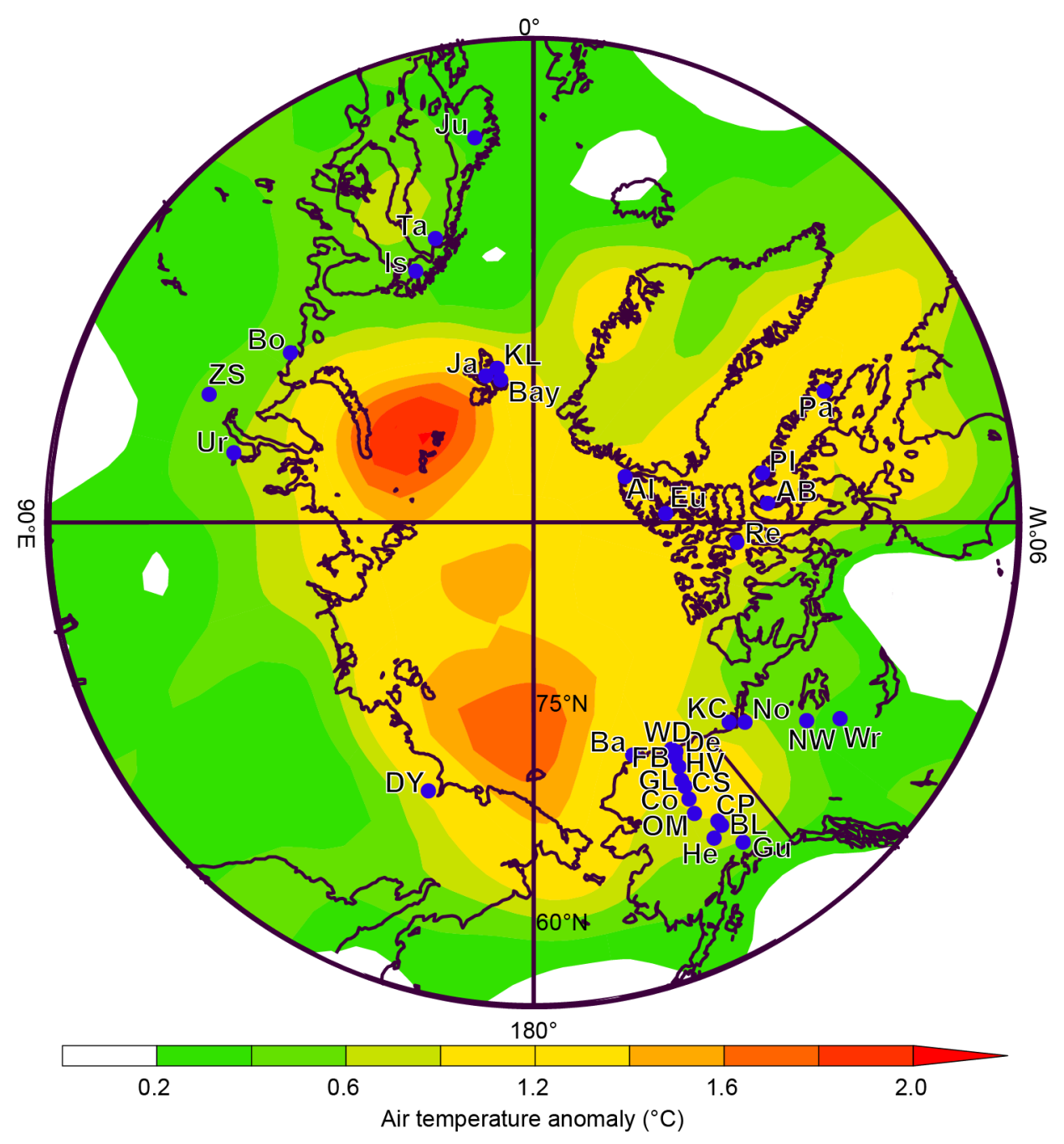

Fig. 5.21. Location of the permafrost temperature monitoring sites (for which data are shown in Fig. 5.22), superimposed on average surface air temperature anomalies $\left({ }^{\circ} \mathrm{C}\right.$ ) during 2000-20 (with respect to the 1981-2020 mean) from the NCEPreanalysis (Kalnay et al. 1996). Reanalysis data provided by the NOAA/ESRL Physical Sciences Division, Boulder Colorado (www.esrl.noaa.gov/psd/). See Table 5.2 for site names. Information about these sites is available at http://gtnpdatabase .org/, http://permafrost.gi.alaska.edu/sites_map, and https://www2.gwu.edu/ calm/.

\section{1) Permafrost temperatures}

Observed increases in permafrost temperatures since the 1980 s were generally greater in colder permafrost at higher latitudes, where the largest increases in air temperature were observed (Figs. 5.21, 5.22). Permafrost temperatures in 2020 (where available) were higher than those observed in 2019 (except some sites in the Barents region) and the highest on record at a majority of the observation sites (Fig. 5.22; Table 5.2). In northern Alaska, for example, temperatures in 2020 were up to $0.1^{\circ} \mathrm{C}$ higher than in 2019 and in the Alaskan interior the 2020 temperature at one site (Old Man) was $>0.1^{\circ} \mathrm{C}$ higher than in 2019 , about $1.4^{\circ} \mathrm{C}$ higher than in 1985 (Figs. 5.22a,b). At Alert in the Canadian High Arctic, permafrost temperatures were also higher in 2020 , and $1.4^{\circ} \mathrm{C}$ higher than at the start of monitoring in 1978 (Fig. 5.22c).

At some sites, recent increases in the rate of permafrost warming have also been observed (Fig. 5.22; Table 5.2). In the Canadian High Arctic, warming rates for 2000-20 were greater than that for the entire 40-year record (Fig. 5.22c; Table 5.2). Throughout the Arctic, the response of permafrost with temperatures close to $0^{\circ} \mathrm{C}$ (i.e., warm permafrost sites) is slower (generally $<0.3^{\circ} \mathrm{C}$ decade $^{-1}$ ) due to latent heat effects related to melting ground ice. Warming at some sites with cold continuous permafrost, however, has been more rapid. For example, in the Beaufort-Chukchi region, permafrost temperatures in northern Alaska have increased by $0.35^{\circ}$ to $0.81^{\circ} \mathrm{C}$ decade $^{-1}$ 
(Fig. 5.22a; Table 5.2). Over a shorter record in northeastern Siberia, permafrost temperatures have increased by $0.4^{\circ} \mathrm{C}$ decade ${ }^{-1}$, similar to the twenty-first century rate for northern Alaska $\left(0.4^{\circ}\right.$ to $0.7^{\circ} \mathrm{C}$ decade $^{-1}$ ).

In the Nordic region, permafrost warming reported by Isaksen et al. (2011) and Etzelmüller et al. (2020) is continuing (Fig. 5.22d). The longest records in high-Arctic Svalbard (Janssonhaugen) and in the discontinuous permafrost regions of Scandinavia (Juvvasshøe) indicate ground temperatures during 2020 were the highest measured since the late 1990s. The highest warming rate is observed on Svalbard at the Janssonhaugen site (Table 5.2), where cold permafrost has warmed by $0.7^{\circ} \mathrm{C}$ per decade since 1998 , similar to the higher latitude sites in other regions. Lower warming rates are observed in the warm discontinuous permafrost of Scandinavia (e.g., Iskoras), similar to warm permafrost in Russia (e.g., Bolvansky \#56) and northwestern North America (Figs. 5.22b,d).
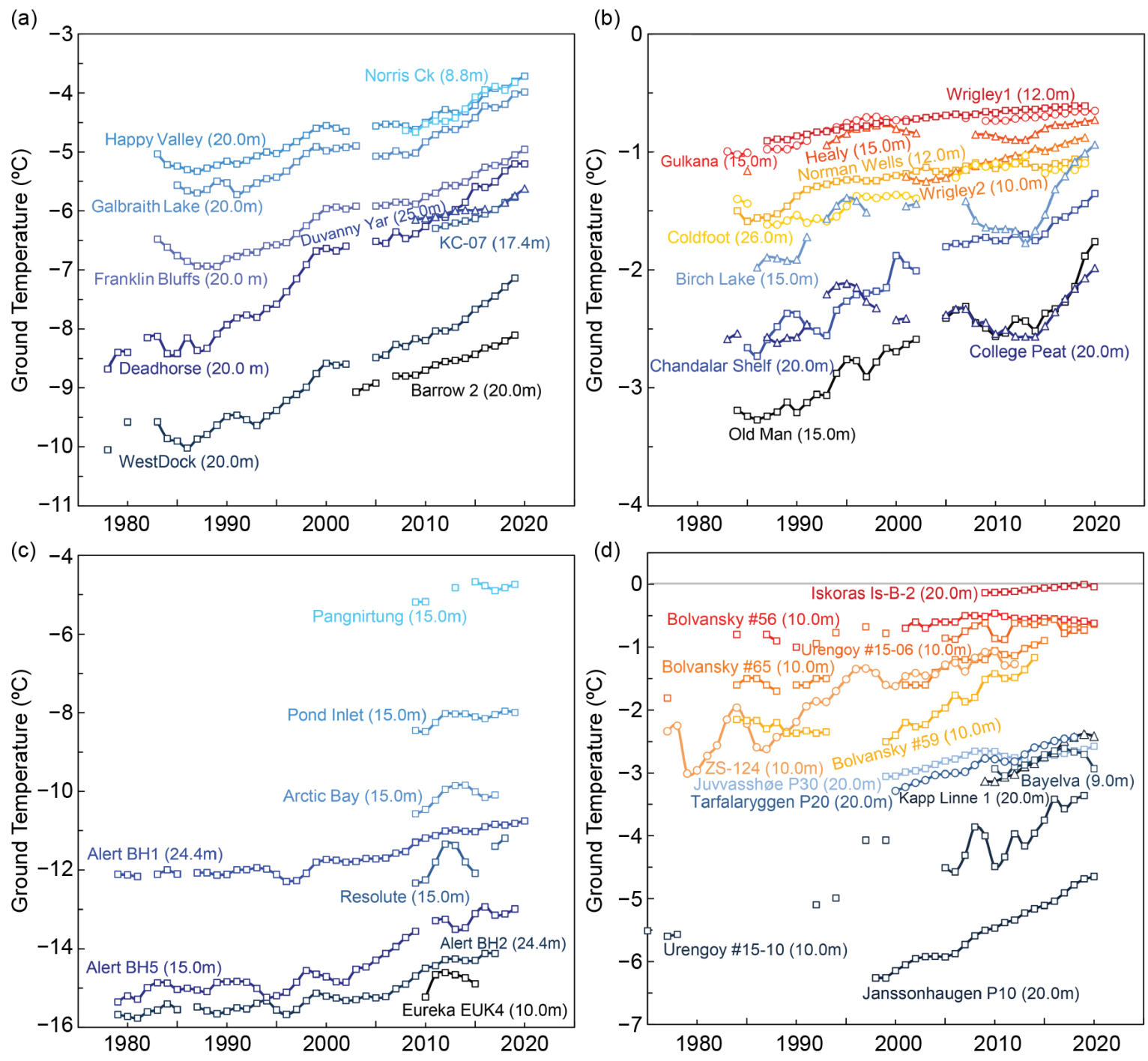

Fig. 5.22. Time series of mean annual ground temperature $\left({ }^{\circ} \mathrm{C}\right)$ at depths of $9-26 \mathrm{~m}$ below the surface at selected measurement sites that fall roughly into priority regions of the Adaptation Actions for a Changing Arctic Project (see Romanovsky et al. 2017): (a) cold continuous permafrost of northwestern North America and northeastern East Siberia (Beaufort-Chukchi region); (b) discontinuous permafrost in Alaska and northwestern Canada; (c) cold continuous permafrost of eastern and High Arctic Canada (Baffin Davis Strait); (d) continuous to discontinuous permafrost in Scandinavia, Svalbard, and Russia/Siberia (Barents region). Temperatures are measured at or near the depth of zero annual amplitude where the seasonal variations of ground temperature are less than $0.1^{\circ} \mathrm{C}$. Note differences in $y$-axis value range. Borehole locations are shown in Fig. 5.21. Data are updated from Christiansen et al. 2010; Romanovksy et al. 2020; Smith et al. 2019; Ednie and Smith 2015; Boike et al. 2018. 
Table 5.2. Rate of change in mean annual ground temperature $\left({ }^{\circ} \mathrm{C}\right.$ decade $\left.^{-1}\right)$ for permafrost monitoring sites shown in Fig. 5.21. For sites where measurements began prior to 2000, the rate of change for the entire available record and the period after 2000 are provided. The periods of record are shown in parenthesis below the rates of change. The names of the stations with record high temperatures in 2020 are shown in red. * denotes sites not reporting in 2020.

\begin{tabular}{|c|c|c|c|}
\hline Subregions & Sites & Entire Record & Since 2000 \\
\hline \multicolumn{4}{|c|}{ Beaufort-Chukchi Region } \\
\hline North of East Siberia & Duvany Yar (DY) & NA & $\begin{array}{c}+0.44 \\
(2009-20)\end{array}$ \\
\hline Alaskan Arctic plain & $\begin{array}{l}\text { West Dock (WD)*, Deadhorse (De), } \\
\text { Franklin Bluffs (FB), Barrow }(\mathrm{Ba})^{*}\end{array}$ & $\begin{array}{c}+0.40 \text { to }+0.81 \\
(1978-2020)\end{array}$ & $\begin{array}{c}+0.49 \text { to }+0.74 \\
(2000-20)\end{array}$ \\
\hline $\begin{array}{l}\text { Northern foothills of the Brooks } \\
\text { Range, Alaska }\end{array}$ & $\begin{array}{l}\text { Happy Valley (HV), Galbraith Lake } \\
\text { (GL) }\end{array}$ & $\begin{array}{c}+0.35 \text { to }+0.44 \\
(1983-2020)\end{array}$ & $\begin{array}{l}+0.44 \text { to }+0.48 \\
\quad(2000-20)\end{array}$ \\
\hline Northern Mackenzie Valley & Norris $\mathrm{Ck}(\mathrm{No})^{*}, \mathrm{KC}-07(\mathrm{KC})^{*}$ & NA & $\begin{array}{c}+0.6 \text { to }+0.8 \\
(2008-19)\end{array}$ \\
\hline \multicolumn{4}{|c|}{ Discontinuous Permafrost Alaska and NW Canada } \\
\hline $\begin{array}{c}\text { Southern foothills of the Brooks } \\
\text { Range, Alaska }\end{array}$ & $\begin{array}{l}\text { Coldfoot (Co) }{ }^{*} \text {, Chandalar Shelf } \\
\text { (CS), Old Man (OM) }\end{array}$ & $\begin{array}{c}+0.08 \text { to }+0.39 \\
(1983-2020)\end{array}$ & $\begin{array}{c}+0.14 \text { to }+0.41 \\
(2000-20)\end{array}$ \\
\hline Interior Alaska & $\begin{array}{c}\text { College Peat (CP), Birch Lake (BL), } \\
\text { Gulkana (Gu), Healy (He) }\end{array}$ & $\begin{array}{c}+0.09 \text { to }+0.30 \\
(1983-2020)\end{array}$ & $\begin{array}{c}+0.04 \text { to }+0.26 \\
\quad(2000-20)\end{array}$ \\
\hline Central Mackenzie Valley & $\begin{array}{l}\text { Norman Wells }(\mathrm{NW})^{*}, \\
\text { Wrigley }(\mathrm{Wr})^{*}\end{array}$ & $\begin{array}{l}\text { Up to }+0.1 \\
(1984-2019)\end{array}$ & $\begin{array}{c}<+0.1 \text { to }+0.2 \\
(2000-19)\end{array}$ \\
\hline \multicolumn{4}{|c|}{ Baffin Davis Strait Region } \\
\hline Baffin Island & Pangnirtung $(\mathrm{Pa})^{*}$, Pond Inlet $(\mathrm{PI})^{*}$ & NA & $\begin{array}{c}+0.4 \\
(2009-19)\end{array}$ \\
\hline High Canadian Arctic & Resolute $(\mathrm{Re})^{*}$ & NA & $\begin{array}{c}+0.7 \\
(2009-18)\end{array}$ \\
\hline High Canadian Arctic & $\begin{array}{l}\text { Alert (Al) @15m* } \\
\text { Alert (Al) @24m }\end{array}$ & $\begin{array}{c}+0.6 \\
+0.4 \\
(1979-2020)\end{array}$ & $\begin{array}{c}+1.1 \\
+0.6 \\
(2000-20)\end{array}$ \\
\hline \multicolumn{4}{|c|}{ Barents Region } \\
\hline North of West Siberia & Urengoy $15-06^{*}$ and $15-08(\mathrm{Ur})^{*}$ & $\begin{array}{c}+0.20 \text { to }+0.48 \\
(1974-2019)\end{array}$ & $\begin{array}{c}+0.08 \text { to }+0.77 \\
(2005-19)\end{array}$ \\
\hline Russian European North & Bolvansky 56, and 65 (Bo) & $\begin{array}{c}+0.05 \text { to }+0.26 \\
(1984-2020)\end{array}$ & $\begin{array}{c}+0.04 \text { to }+0.48 \\
\quad(2001-20)\end{array}$ \\
\hline Svalbard & $\begin{array}{c}\text { Janssonhaugen (Ja), Bayelva (Bay), } \\
\text { Kapp Linne } 1 \text { (KL) }\end{array}$ & $\begin{array}{c}+0.7 \\
(1998-2020)\end{array}$ & $\begin{array}{c}+0.6 \text { to }+0.8 \\
(2000-20)\end{array}$ \\
\hline Northern Scandinavia & Tarfalarggen (Ta), Iskoras Is-B-2 (Is) & NA & $\begin{array}{c}+0.1 \text { to }+0.5 \\
(2000-20)\end{array}$ \\
\hline Southern Norway & Juvvasshøe (Ju) & $\begin{array}{c}+0.2 \\
(1999-2020)\end{array}$ & $\begin{array}{c}+0.2 \\
(2000-20)\end{array}$ \\
\hline
\end{tabular}

\section{2) Active layer thickness}

With the exception of the Mackenzie Valley in northwest Canada (at which thaw tubes are used), active layer data reported here were measured by mechanical probing across grids varying from 1 ha to $1 \mathrm{~km}^{2}$ in size and representative of regional landscapes (Shiklomanov et al. 2012). Increases in ALT are observed over the period of record in some regions but for other regions trends are less evident.

The average ALT $(0.46 \mathrm{~m})$ for 12 North Slope of Alaska sites reporting in 2020 was $0.015 \mathrm{~m}$ below the 2003-12 mean for the same 12 sites and $0.06 \mathrm{~m}$ lower than in 2019 (Fig. 5.23). Observers from local communities were able to make measurements so that some 2020 ALT data were collected. Interior Alaska continues to exhibit pronounced ALT increases over the last 25 years, with a new record average of $0.92 \mathrm{~m}$ in 2020. 
Sites in Svalbard displayed similar ALT values to the two previous years, values that were approximately $0.13 \mathrm{~m}$ above the 2003-12 mean (Fig. 5.23). ALT for Greenland in 2020 was similar to that in 2019, $0.08 \mathrm{~m}$ above the 2003-12 mean (Strand et al. 2020).

Sites in West and East Siberia reported increased ALT in 2020, continuing the general trend, with the average ALT $(1.46 \mathrm{~m})$ for West Siberia being a new record maximum for the observation period (Fig. 5.23). Significant ALT reduction was reported in 2020 for sites in the Russian European North and Chukotka, but these values are based on fewer sites and may not be representative of regional trends previously reported (Abramov et al. 2019; Vasiliev et al. 2020).
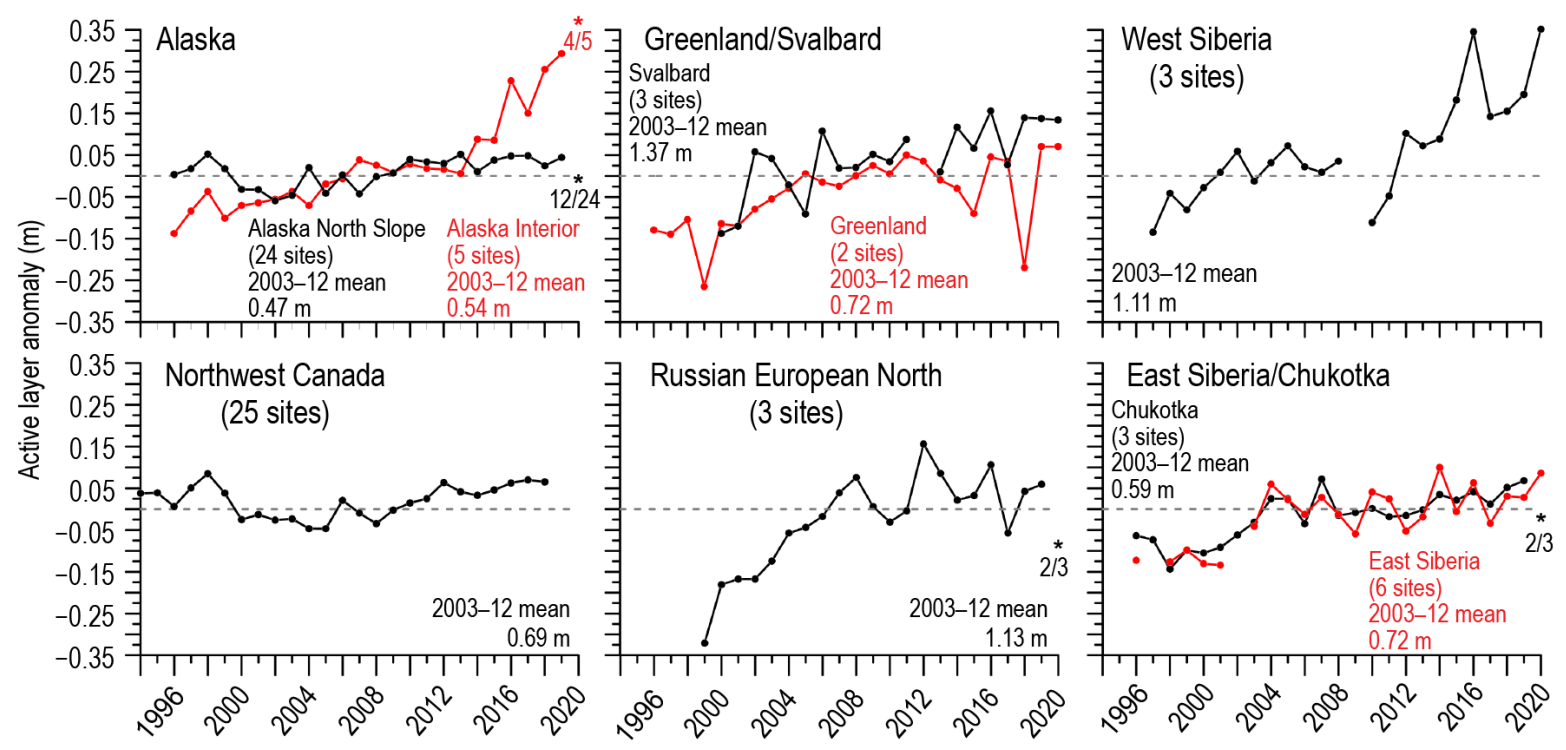

Fig. 5.23. Long-term active layer thickness anomalies in six different Arctic regions as observed by the Circumpolar Active Layer Monitoring (CALM) program. The data are shown as annual anomalies $(\mathrm{m})$ relative to the mean value for the reference period 2003-12. Positive and negative anomaly values indicate the active layer is thicker or thinner than the 10-year mean values, respectively. The number of sites varies by region (numbers provided on figure), because only sites with $>\mathbf{2 0}$ years of continuous thaw depth observations from the end of the thaw season were included. Asterisks on the figure represent $\mathbf{2 0 2 0}$ data, as observations from fewer sites (number provided beside asterisks) were possible due to pandemic-related restrictions. Site-specific data are available at www2.gwu.edu/ calm/.

i. Tundra greenness-G. V. Frost, M. J. Macander, U. S. Bhatt, H. E. Epstein, L. T. Berner, J. W. Bjerke, B. C. Forbes, S. J. Goetz, M. J. Lara, T. Park, G. K. Phoenix, M. K. Raynolds, H. Tømmervik, and D. A. Walker

Occupying Earth's northernmost lands, the Arctic tundra biome is a focal point of global environmental change because vegetation and underlying permafrost soils are strongly influenced by warming air temperatures and interactions with sea ice loss in the adjacent Arctic Ocean (Lawrence et al. 2008; Bhatt et al. 2010; Serreze and Barry 2011; sections 5b-d). One of the most striking consequences of the Arctic's warming climate has been an increase in the productivity ("greenness") of tundra vegetation, which is largely governed by summer temperature (Berner et al. 2020; Bjorkman et al. 2020). Tundra greenness has been monitored by Earth-observing satellites since 1982 and a growing constellation of spaceborne sensors provide increasingly detailed observations of Arctic ecosystems.

The spaceborne record of global vegetation productivity began in late 1981 using the Advanced Very High Resolution Radiometer (AVHRR), a sensor that collects daily observations and continues to operate onboard polar-orbiting satellites today. The long-term dataset reported here is the Global Inventory Modeling and Mapping Studies 3g V1.2 dataset (GIMMS-3g+), which is based on corrected and calibrated AVHRR data with a spatial resolution of about $8 \mathrm{~km}$ (Pinzon and Tucker 2014). At the time of this writing, however, processed GIMMS-3g+ data are available only through the 2019 growing season. Therefore, we also report observations from the Moderate Resolution 
Imaging Spectroradiometer (MODIS), a more modern sensor with a higher spatial resolution of $500 \mathrm{~m}$ that became operational in 2000. Both AVHRR and MODIS monitor vegetation productivity using the Normalized Difference Vegetation Index (NDVI), a spectral dimensionless metric of vegetation productivity that exploits the unique way in which green vegetation reflects light in the red and near-infrared wavelengths. Here we summarize the GIMMS-3g+ and MODIS records for Maximum NDVI (MaxNDVI), the peak yearly value that is strongly correlated with the biomass of aboveground vegetation during midsummer (Raynolds et al. 2012). For MODIS, we computed MaxNDVI from daily Nadir Bidirectional Reflectance Distribution Function Adjusted Reflectance data (MCD43A4, version 6; Schaaf 2020).

The GIMMS-3g+ and MODIS records both indicate that MaxNDVI has increased across most of the circumpolar Arctic during 1982-2019 and 2000-20, respectively (Figs. 5.24a,b). Although the two datasets consider different periods, several Arctic regions stand out as change "hotspots" in both records. In North America, greening has been strongest in northern Alaska and mainland Canada, while trends have been flat or negative ("browning") in parts of the Canadian Arctic Archipelago. In Eurasia, strong greening has occurred in the Russian Far East (Chukotka), but browning is evident in the East Siberian Sea sector and portions of the Taymyr Peninsula. Trends in northwestern Siberia and the European Arctic, however, are somewhat mixed for both time periods. Regional differences in Arctic greenness highlight that ecosystem responses to climate change are also influenced by the local properties of sea ice, permafrost, seasonal snow, soil composition and moisture, disturbance processes, wildlife, and human activities (Buchwal et al. 2020; Skarin et al. 2020; Epstein et al. 2021; Kemppinen et al. 2021; Kropp et al. 2021).

The MODIS MCD43A4 record complements the GIMMS-3g+ dataset for the 21-year period since 2000 and provides observations for the 2020 growing season. The mean circumpolar MaxNDVI value in 2020 was by far the highest in the MODIS record (3.4\% higher than the previous high set in 2012). Circumpolar MaxNDVI increased 4.0\% from the 2019 value; increases from the previous year were larger for the North American Arctic (5.6\%) than for Eurasia (2.0\%). The overall trend in circumpolar MaxNDVI remains strongly positive and circumpolar values have exceeded the 21-year mean in nine of the last 10 growing seasons (Fig. 5.25). The GIMMS-3g+ record also indicates increasing mean circumpolar MaxNDVI for both the full record (1982-2019) and the period of overlap with MODIS (2000-2019).
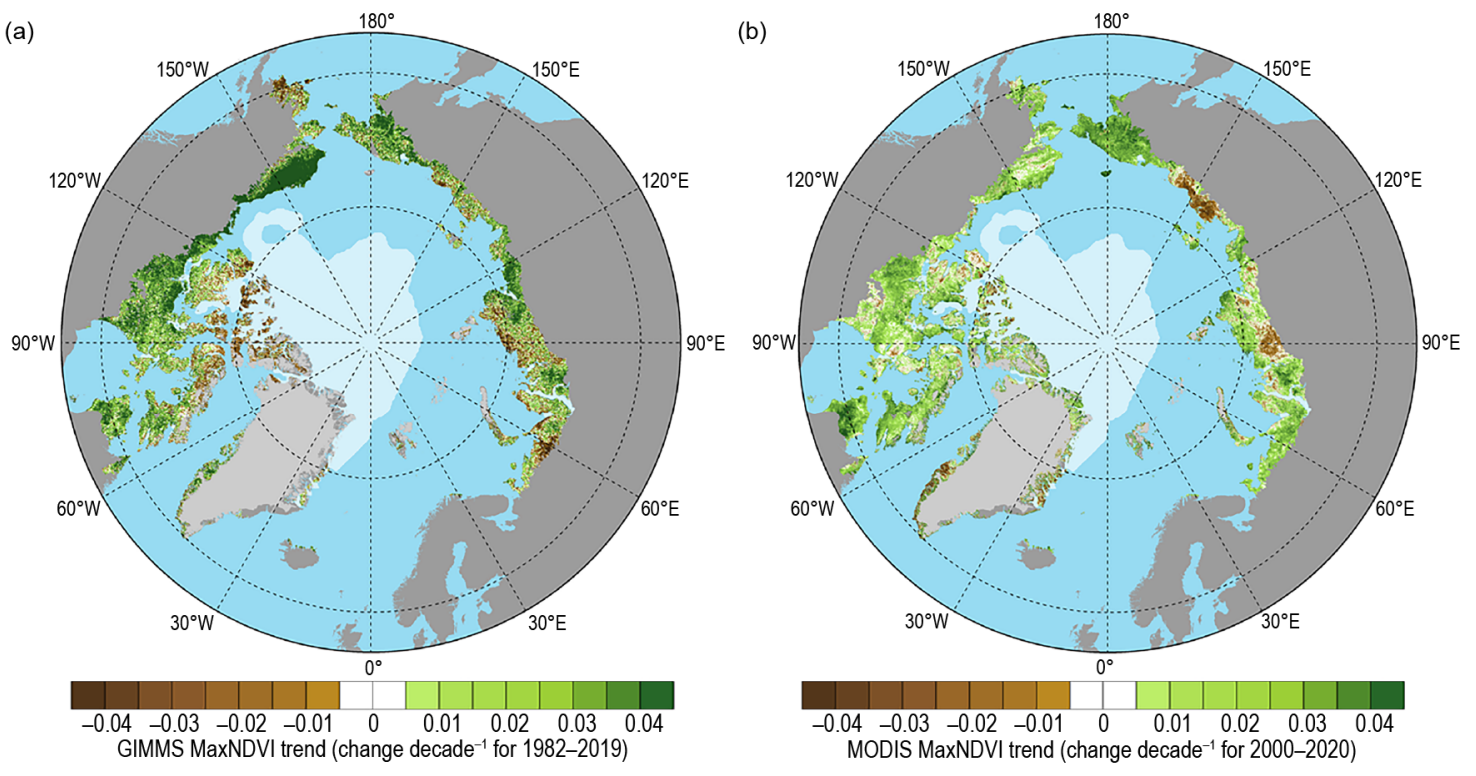

Fig. 5.24. Magnitude of the MaxNDVI trend calculated as the change decade ${ }^{-1}$ over a least squares, linear fit trend line for (a) 1982-2019 based on the GIMMS-3g+ dataset, and (b) 2000-20 based on the MODIS MCD43A4 dataset. GIMMS-3g+ data for $\mathbf{2 0 2 0}$ were not available for this report due to data-processing requirements. 


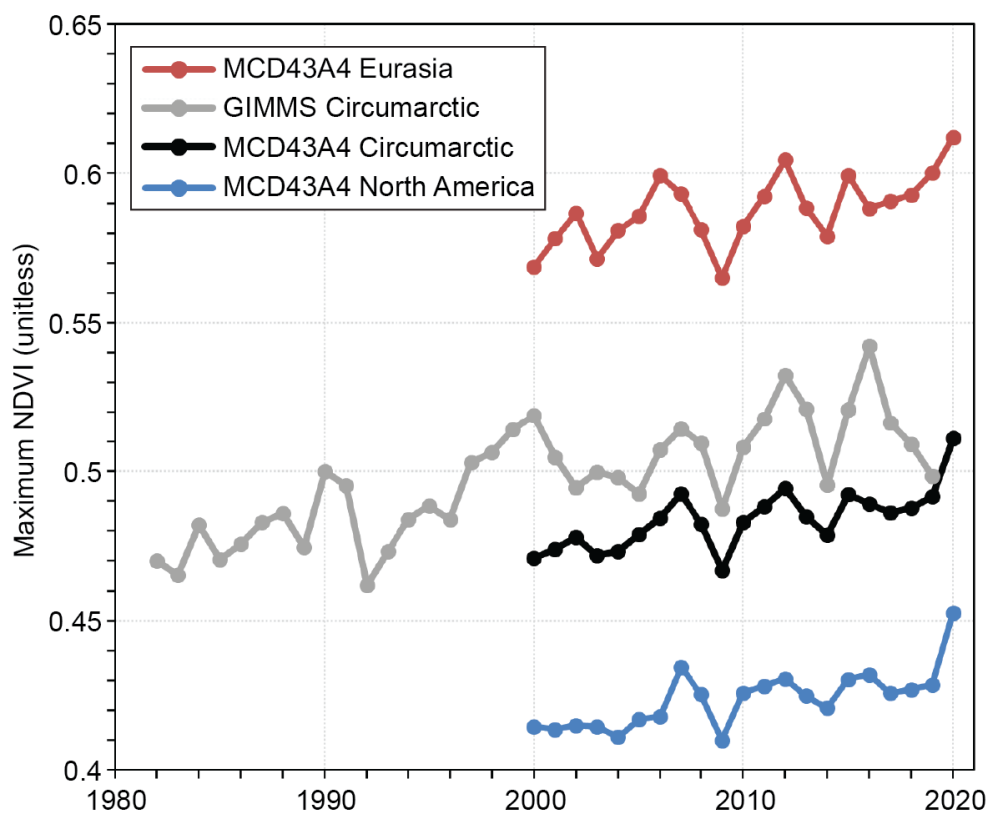

Fig. 5.25. Time series of MaxNDVI from the MODIS MCD43A4 (2000-20) dataset for the Eurasian Arctic (red), North American Arctic (blue), and the circumpolar Arctic (black), and from the long-term GIMMS-3g+ (1982-2019) dataset for the circumpolar Arctic (in gray).

Recent remote sensing- and field-based studies provide context for understanding changes in vegetation and ground conditions that correlate with MaxNDVI trends. Many site-specific studies have detected increased growth and expansion of tundra shrubs, such as birches (Betula), willows (Salix), and alders (Alnus; Andreu-Hayles et al. 2020; Liljedahl et al. 2020; Shevtsova et al. 2020). Spaceborne observations also indicate changes in growing season length and the timing of phenological events such as spring snowmelt (section 5f), vegetation green-up, and autumn senescence. For example, a recent analysis of vegetation phenology using MODIS NDVI data revealed that the 2020 Arctic growing season began and ended on average over 5 days earlier and 2 days later, respectively, relative to the 2000-10 baseline (section 2h4). The start of the 2020 growing season was particularly early in the Eurasian Arctic, where green-up occurred about 9 days earlier than average due to warm spring temperatures and early snowmelt. In Svalbard, Vickers et al. (2020) evaluated snow cover using MODIS data and concluded that the length of the growing season increased by 4.2 days decade ${ }^{-1}$ since 2000. Moreover, a study of MaxNDVI over central Svalbard from 1986 to 2015 linked local greening to increasing temperature; however, the pace of greening was slower during the second half of the study period, which may be attributed to more frequent extreme winter warming events that can damage vegetation (Vickers et al. 2016).

Die-back or removal of vegetation can also be caused by landscape disturbances, including wildfire (Heim et al. 2021; Sidebar 5.1) and permafrost thaw (Verdonen et al. 2020; Chen et al. 2021; Swanson 2021; section 5h), as well as herbivore and pest outbreaks (Lund et al. 2017; Prendin et al. 2020). Severe event-driven browning has led to major reductions in carbon dioxide uptake by tundra plants in the European Arctic (Treharne et al. 2020). While Arctic warming is likely to continue to drive greening, drivers of browning are also increasing in frequency (Landrum and Holland 2020; Myers-Smith et al. 2020; Wu et al. 2020), highlighting the emergence of increased variability as a component of Arctic climate change.

j. Ozone and ultraviolet radiation-G. H. Bernhard, V. E. Fioletov, J.-U. Grooß, I. Ialongo, B. Johnsen, K. Lakkala,

G. L. Manney, R. Müller, and T. Svendby

Past emissions of man-made chlorine-containing substances have caused substantial chemical depletion of ozone in the stratosphere (WMO 2018). The resulting ozone loss led to increases of ultraviolet (UV) radiation at Earth's surface with adverse effects on human health and the 
environment (EEAP 2019; Neale et al. 2021). The chemical destruction of polar ozone occurs within a cold stratospheric cyclone known as the polar vortex, which forms over the North Pole every year during winter (WMO 2018). The polar vortex between December 2019 and March 2020 was the strongest on record since the start of satellite observations in 1979/80 (Lawrence et al. 2020) and affected stratospheric ozone concentrations in the Northern Hemisphere (NH) until August 2020.

\section{1) Ozone}

Chemical processes that drive ozone depletion in the polar stratosphere are initiated at temperatures below about $195 \mathrm{~K}\left(-78^{\circ} \mathrm{C}\right)$ at altitudes of approximately 15 to $25 \mathrm{~km}$. These low temperatures lead to the formation of polar stratospheric clouds (PSCs), which act as a catalyst to transform inactive forms of chlorine-containing substances into active, ozone-destroying chlorine species. Temperatures were low enough for PSC formation by mid-November 2019, earlier than in any previous year since the start of observations by the Aura Microwave Limb Sounder (MLS) in 2004 (Manney et al. 2020; DeLand et al. 2020). Temperatures in the lower stratosphere remained conducive to PSC existence until 25 March 2020, which is about 1 month longer than typical (Lawrence et al. 2020). The number of days with temperatures low enough for sustaining PSCs was the highest since at least 1980 (Lawrence et al. 2020).

Because of the exceptionally strong, cold, and persistent stratospheric polar vortex, the potential for chemical ozone depletion was the highest since at least 2004. The MLS measurements near $16 \mathrm{~km}$ (the approximate altitude where most ozone loss typically occurs) show chlorine activation starting in mid-November 2019 and ozone declining by December (Fig. 5.26). From February 2020 onward, ozone concentrations were the lowest in the MLS record and remained below past measurements (2004-19) until May, exceeding the ozone loss observed in the previous record years of 2010/11 and 2015/16.

The low ozone concentrations in the lower stratosphere during winter/spring 2019/20 led to exceptionally small Arctic total ozone columns (TOC; i.e., ozone amounts integrated from the surface to the top of the atmosphere) between January and July 2020. The TOCs in February, March, and April 2020 averaged over the polar cap (latitudes $\geq 63^{\circ} \mathrm{N}$ ) were the lowest of the satellite record starting in 1979 (Lawrence et al. 2020), with near-record lows also for January, May,

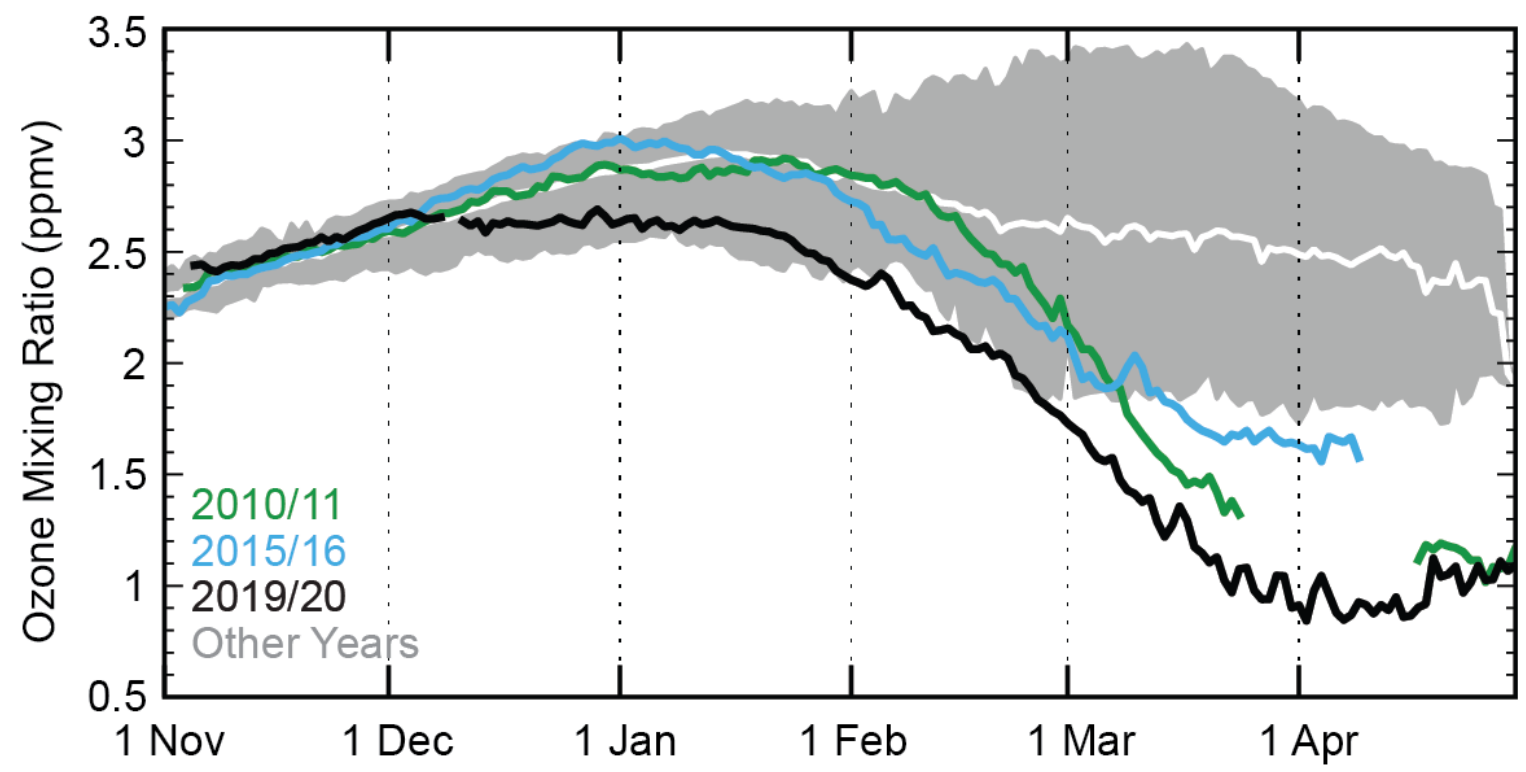

Fig. 5.26. Average ozone concentrations (expressed as ozone mixing ratio in ppmv) at an altitude of $\sim 16 \mathrm{~km}$ for the area bounded by the polar vortex measured by Aura MLS. Data from 2019/20 (black), 2010/11 (green), and 2015/16 (cyan) are compared with the average (solid white) and minimum/maximum range (gray shading) from 2004/05 to 2018/19, excluding 2010/11 and 2015/16. The gap in the 2010/11 record is due to missing data; the 2015/16 record is foreshortened by the early vortex breakup that year (Manney and Lawrence 2016). 
June, and July. While chemical ozone destruction ceased at the beginning of April 2020, TOCs over the NH remained depressed between May and August as ozone-depleted polar air mixed with air from midlatitudes.

Figure 5.27 focuses on the variation in TOC between 1979 and 2020 for March alone because March is the month with the largest potential for chemical ozone depletion in the Arctic (WMO 2018). Instead of illustrating the mean polar cap TOC discussed above, Fig. 5.27 shows the March minimum of the daily mean TOC within an area that encloses the polar vortex and is surrounded by the $63^{\circ} \mathrm{N}$ contour of "equivalent latitude" (Butchart and Remsberg 1986). In March 2020, the minimum Arctic daily TOC was 295 Dobson units (DU), which was the lowest value since the start of satellite observations in 1979 and 21\% (79 DU) below the average of the observational record (374 DU).

Spatial deviations of monthly average TOCs from past (2005-19) averages (Fig. 5.28a) were estimated from Ozone Monitoring Instrument (OMI) measurements. In March 2020, TOC anomalies as large as $-40 \%$ and exceeding 3 standard deviations were measured over northern Canada and the adjacent Arctic Ocean. In April, TOC anomalies up to -35\% and exceeding 3 standard deviations were observed for virtually all areas north of $60^{\circ} \mathrm{N}$. During the breakup of the polar vortex in May (Manney et al. 2020), areas with abnormally low (>3 std. dev.) TOCs still persisted over Siberia.

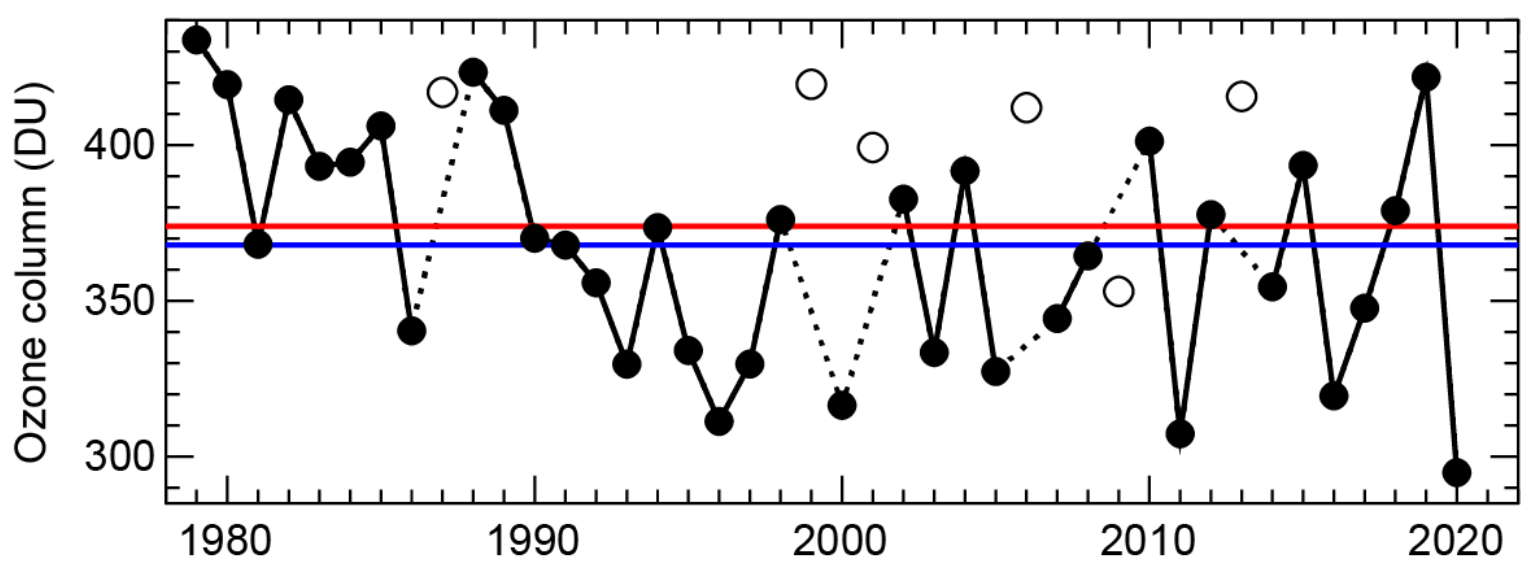

Fig. 5.27. Minimum of the daily average total ozone column (Dobson units, DU) for Mar poleward of $63^{\circ} \mathrm{N}$ equivalent latitude (Butchart and Remsberg 1986). Open circles represent years in which the polar vortex was not well-defined in Mar, resulting in relatively high values owing to mixing with lower latitude air masses and a lack of significant chemical ozone depletion. Red and blue lines indicate the average total ozone column for 1979-2019 and 2005-19, respectively. Ozone data for 1979-2016 are based on the combined total column ozone database version 3.4 produced by Bodeker Scientific (www.bodekerscientific.com/data/total-column-ozone). Ozone data for 2017-20 are from the OMI. The graph is adapted from Müller et al. (2008) and WMO (2018), updated using ERA5 reanalysis data (Hersbach et al. 2020) for determining equivalent latitude. 

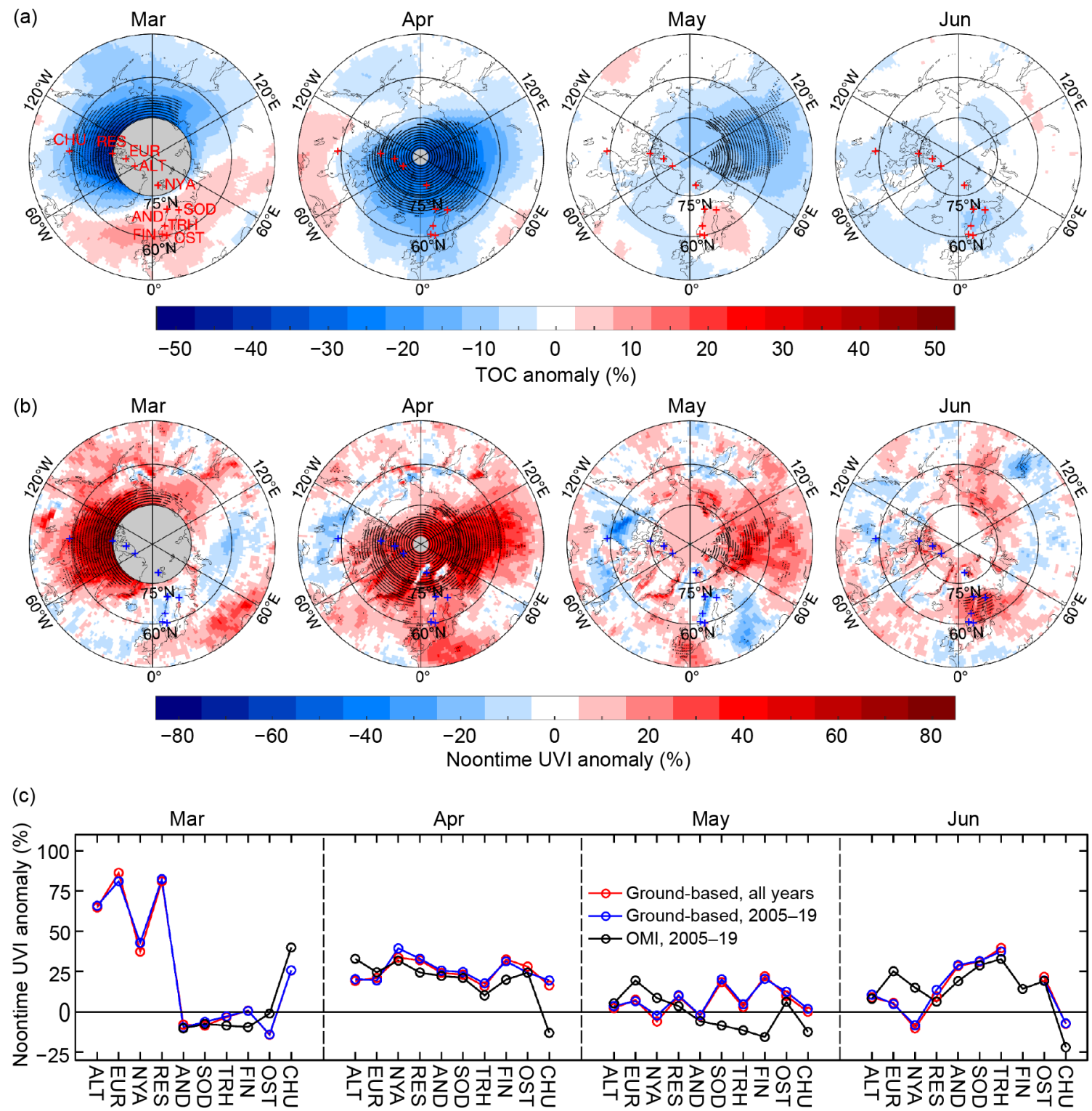

Fig. 5.28. Monthly mean anomaly maps of (a) total ozone column (\%) and (b) noontime UV index (\%) for Mar, Apr, May, and Jun 2020 relative to 2005-19 means. Stippling indicates pixels where anomalies exceed 3 std dev. Gray-shaded areas centered at the North Pole in the maps for Mar and Apr indicate latitudes where no Ozone Monitoring Instrument (OMI) data are available because of polar darkness. Locations of ground stations are indicated by crosses in every map, with labels added to the first map. Maps are based on the ОMTO3 Level 3 total ozone product (Bhartia and Wellemeyer 2002). (c) Anomalies of monthly means of the noontime UV index (\%) for 2020 derived from measurements at 10 ground stations (north to south along $x$-axis) relative to all years with available data (red) and 2005-19 (blue). The black datasets indicate anomalies for the same stations derived from OMI measurements (b) relative to 2005-19. Site acronyms are ALT: Alert (83N); EUR: Eureka $\left(80^{\circ} \mathrm{N}\right)$; NYA: Ny-Ålesund $\left(79^{\circ} \mathrm{N}\right) ;$ RES: Resolute $\left(75^{\circ} \mathrm{N}\right) ;$ AND: Andøya $\left(69^{\circ} \mathrm{N}\right)$; SOD: Sodankylä $\left(67^{\circ} \mathrm{N}\right) ;$ TRH: Trondheim $\left(63^{\circ} \mathrm{N}\right) ;$ FIN: Finse $\left(61^{\circ} \mathrm{N}\right)$; OST: Østerås $\left(60^{\circ} \mathrm{N}\right)$; and CHU: Churchill $\left(59^{\circ} \mathrm{N}\right)$. Figure adapted from Bernhard et al. (2020).

\section{2) Ultraviolet radiation}

UV radiation is quantified with the UV index (UVI), which measures the ability of UV radiation to cause erythema (sunburn) in human skin (WHO 2002). In addition to its dependence on TOC, the UVI depends on the sun angle, clouds, aerosols, and surface albedo (Weatherhead et al. 2005). In the Arctic, the UVI scale ranges from 0 to about 7; UVI values north of $80^{\circ} \mathrm{N}$ remain below 3.

On several days in 2020, UVIs observed by ground-based radiometers at 10 sites distributed across northern Canada and Europe exceeded historical (2005-19) means by more than 75\% (Bernhard et al. 2020). At the Canadian sites, these means were surpassed by more than 6 standard deviations. Monthly mean UVIs were $75 \%$ higher than normal in northern Canada in March 
2020 and elevated by about 25\% at all sites in April 2020 (Bernhard et al. 2020). These large relative anomalies occurred early in the year when the Sun is still low in the sky. Therefore, UVI increases remained small in absolute terms and did not exceed typical summertime UVI values under clear skies.

Figure 5.28b quantifies spatial differences in monthly average noontime UVIs from past (2005-19) averages based on measurements by OMI. Areas with high UVIs roughly match areas with low TOCs (Fig. 5.28a), but UVI anomalies have larger spatial variability because of their added dependence on clouds. In March 2020, monthly average UVI anomalies over the Canadian Arctic and the adjacent Arctic Ocean ranged between 30\% and 70\%, often exceeding 3 standard deviations. In April 2020, UVI anomalies were positive over a vast area, including northern Canada, Greenland, northern Europe, and Siberia. The maximum anomaly was 78\% and anomalies exceeded 3 standard deviations almost everywhere north of $70^{\circ} \mathrm{N}$. In May 2020, UVI anomalies of up to $60 \%$ and exceeding 3 standard deviations were measured over Siberia. The UVIs in June were elevated by up to $30 \%$ over parts of Norway, Sweden, and Finland, resulting from a combination of negative TOC anomalies (Fig. 5.28a) and unusually fair weather with several cloudless days (Bernhard et al. 2020). Ground-based measurements generally confirm UVI anomalies derived from satellite data (Fig. 5.28c). 


\section{Introduction and methods}

Western science and Indigenous observations in the Arctic have revealed dramatic environmental changes, with potentially catastrophic consequences to Arctic and global ecosystems and society (e.g., Thoman et al. 2020; Slats et al. 2019). However, gaps and structural challenges in observing systems have hampered scientific understanding of these changes (Lee et al. 2019; Murray et al. 2018; AOS EOC 2018). Among other factors, Arctic observing systems face extreme physical conditions, limited regional infrastructure, and a patchwork of jurisdiction and policy approaches across eight Arctic nations and other observing partners. These challenges, coupled with urgent societal and scientific needs, led to the vision of an internationally-coordinated Arctic Observing Network (AON; NRC 2006) with sustained, integrated observations targeting the most critical aspects of a rapidly changing Arctic. Tracking, evaluating, and continuously improving the AON is a critical effort. Annual Arctic Report Card (ARC; https://arctic.noaa.gov/Report-Card/) assessments provide a 15-year record (2006-20) of shifting Arctic conditions with consistent studies on seven key variables, identified since 2007 as "Vital Signs" reports (topics listed in Table SB5.1; Thoman et al. 2020). These Vital Signs are annually mirrored in the BAMS State of the Climate Arctic Chapter's headings and provide a substantial foundation for a retrospective analysis exploring how the AON's support of Arctic indicator variables has changed during 2007 to 2020.

This study examines the quality of the observation and modelderived data products used for each ARC Vital Sign report to establish the annual status of key variables (e.g., terrestrial snow cover extent) in the context of their long-term trends. Authors from each Vital Sign validated the catalog of data products and independently rated their performance. A value tree assessment (VTA) was used to systematically link observational inputs (i.e., satellite or in situ measurements) to the value-added data product and application outputs they support and assess their performance (IDA 2017). The VTA methodology weighs the relative contributions of individual observing systems and data products, while revealing linkages throughout the system. VTA can also reveal where value is limited or terminates due to technical hurdles. VTA provides funders and policymakers with evidence to strategically fill observing gaps and remove impediments to value propagation. For example, these methodologies were employed in the national assessment of civil earth observations called for by Congress (OSTP 2014) and are related to methods used within USGS, NOAA, and other agencies to evaluate existing observing systems and identify needs (USGS 2019).

\section{Findings}

Since 2007, reports on these ARC Vital Sign indicators employed more than 100 different data products to support key findings of Arctic change. In 2020, the 27 data products employed were derived from gridded products based on satellite or blended analyses (14), modeled products (8), and in situ networks (5). Reanalyses and other model products depend on a complex set of observational inputs, the full accounting of which exceeds the scope of this analysis. The need for multinational and interagency support for the systems that underpin Arctic indicator reports is evident in the mix of products, which are developed for both operational (8) and research (19) purposes and supported by the United States, Canada, Japan, and European nations. To support transparency around the key findings of the 2020 ARC, a searchable online catalog of the 2020 data products is now available on the NSF Arctic Data Center website (https://arcticdata.io/catalog/portals/reportcard).

The VTA revealed the diverse observing and data inputs required to develop the annual status of key Arctic variables (Fig. SB5.3 and Acronyms section). The most widely used observing systems are the Passive Microwave (PM) satellite (currently DMSP/SSMIS), NASA's Moderate Resolution Imaging Spectroradiometer (MODIS) satellite instrument, and in situ automated weather stations (AWS). With persistent atmospheric reanalysis and satellite retrieval issues near the surface in high latitudes, AWS networks continue to provide critical insights. The PM provides high utility for cryospheric observations, even under cloudy conditions, making it a good fit for the Arctic. The dependence of five indicators on the PM (four shown in Fig. SB5.3; a fifth, Ocean Primary Productivity, did not meet the threshold for inclusion in the graphic, which only displays the most critical observations and data products in each category) reveals an important vulnerability given that the last satellite is beyond its planned life without a replacement scheduled (Lavergne et al. 2019). This contrasts with the Normalized Difference Vegetation 


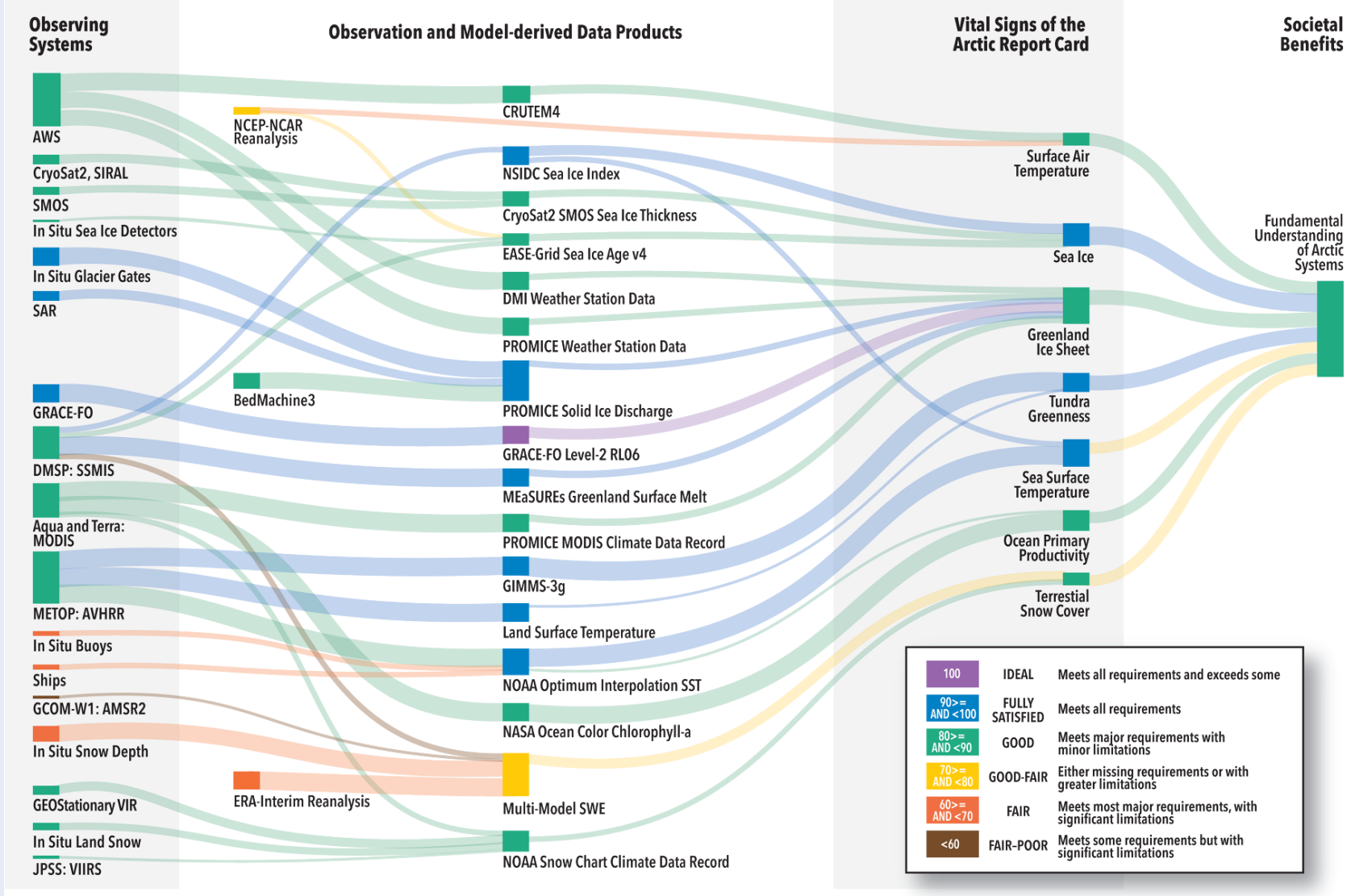

Fig. SB5.3. Value tree assessment (VTA) for the ARC2020. Observing system value in support of the seven ARC Vital Signs propagates forward (left to right) through observation and model-derived data products, then Vital Signs to societal benefit. In this VTA, the primary benefit to society is increased scientific understanding of Arctic systems. Color coding indicates a performance score for nodes (see insert) averaged across all uses; links are weighted (indicated by line thickness) based on their criticality to downstream value. See Acronyms list.

Index (NDVI, section $5 \mathrm{i}$ ) that is supported by multiple systems (MODIS, AVHRR, and LandSat). Authors choose to work with AVHRR, despite its lower spatial resolution, because the longer record (compared to MODIS) and comprehensive coverage (compared to LandSat) better supports the goals of the ARC.

For the value tree reanalysis, authors rated the performance of their report (i.e., how well the essay conveys long-term trends in the subject of interest) and how it has changed since it first appeared in the ARC (Table SB5.1). Over the last 15 years, five of seven indicators have seen moderate $(+10)$ to large $(+40)$ performance improvements. Taken as a composite across all indicator topics, the quality of the AON and its data products has risen from a performance score of 61 to 84, or from "Fair" to "Good" (see Key in Fig. SB5.3). These ratings are specific to the ARC itself and not reflective of the performance of the AON across all applications. While these improvements are encouraging, there are still significant gaps in the AON of relevance to key Arctic indicators, with the most pronounced gaps noted in
Table SB5.1. These gaps also indicate opportunities for targeted improvements of the AON and its data products.

\section{Conclusions}

Through this VTA, we see that the data products and observing systems that underlie key indicators of Arctic change, specifically the ARC Vital Signs (mirrored in this chapter), have matured since 2007 due to sponsorship of new observations, focused improvements to existing data products, and a growing scientific understanding of Arctic processes. While the improvements are encouraging, the results of this analysis are focused only on Western science observations and are biased, as the ARC preferentially reports variables that are consistently possible to observe in the Arctic. The AON's quality is a critical indicator that should be monitored; VTA methods provide a starting point for such comprehensive analyses. 


\begin{tabular}{|c|c|c|c|}
\hline Vital Sign & $\begin{array}{l}\text { Performance } \\
\text { Rating, } 2007 \text { or } \\
\text { first year in the } \\
\text { ARC }\end{array}$ & $\begin{array}{l}\text { Performance } \\
\text { Rating, } 2020\end{array}$ & $\begin{array}{l}\text { What accounts for positive changes in the ratings? }(+) \\
\text { What is limiting better performance? }(-)\end{array}$ \\
\hline $\begin{array}{l}\text { Surface air } \\
\text { temperature }\end{array}$ & 60 & 70 & $\begin{array}{l}+\quad \text { Improvements in high latitude models and datasets } \\
+\quad \text { Additional monitoring sites (AWS sites in Alaska and coastal Greenland } \\
\text { and on the Greenland Ice Sheet) } \\
\text { - } \quad \text { Need for improved accuracy in Arctic reanalyses }\end{array}$ \\
\hline Terrestrial snow cover & 40 & 80 & $\begin{array}{l}+\quad \text { Longer data records } \\
+\quad \text { Additional reference data sets analyzed for comparison } \\
\text { - } \quad \text { Satellite capabilities, such as Ku-band radar, are needed, especially in } \\
\text { mountainous areas } \\
\text { - } \quad \text { Limited snow water equivalent observations }\end{array}$ \\
\hline Greenland Ice Sheet & 50 & 80 & $\begin{array}{ll}+ & \text { Longer data records } \\
+ & \text { Additional monitoring sites } \\
+ & \text { Increased understanding of natural processes } \\
+ & \text { New satellite capabilities (e.g., GRACE comprehensive mass balance, } \\
& \text { ICESat- } 2 \text {, Sentinel- } 1 \text { ice velocities) } \\
+\quad \text { Expanded field of researchers } \\
-\quad \text { Limited regional model data } \\
-\quad \text { Data limited due to clouds and polar night } \\
\text { - } \quad \text { Continued sparse in situ observations due to region size }\end{array}$ \\
\hline Sea ice & 60 & 80 & $\begin{array}{l}+\quad \text { Longer data records } \\
+\quad \text { Ice thickness estimates provided in new satellite capabilities (CryoSat-2 and } \\
\text { ICESat-2) } \\
-\quad \text { Low spatial resolution of datasets, especially in coastal zone } \\
-\quad \text { Time-lag in data delivery for snow depth and melt ponding over sea ice, } \\
\text { melt-onset, and freeze-up date } \\
-\quad \text { Limited capabilities for some parameters during summer melt season }\end{array}$ \\
\hline $\begin{array}{l}\text { Sea surface } \\
\text { temperature }\end{array}$ & 90 & 90 & $\begin{array}{l}\text { + Improved spatial coverage, accuracy, and reliability in datasets } \\
\text { - } \quad \text { Low spatial resolution of datasets, especially in coastal zone }\end{array}$ \\
\hline $\begin{array}{l}\text { Ocean primary } \\
\text { productivity }\end{array}$ & 80 & 80 & $\begin{array}{l}+\quad \text { Longer data records } \\
\text { - Accuracy of chlorophyll-a concentrations in Arctic waters } \\
\text { - Limited efficacy of remote sensing technology due to cloudy and ice- } \\
\text { covered Arctic conditions }\end{array}$ \\
\hline Tundra greenness & 50 & 90 & $\begin{array}{l}\text { + } \quad \text { Longer data records } \\
+\quad \text { Improvements in high latitude models and datasets } \\
\text { - } \quad \text { Limited efficacy of remote sensing technology due to cloudy and } \\
\text { snowy Arctic conditions } \\
\text { - } \quad \text { Joint needs of record length and fine-scale temporal and spatial } \\
\text { resolution not met by existing datasets } \\
\text { _ } \quad \text { Lack of consistency across different coarse-resolution NDVI datasets }\end{array}$ \\
\hline
\end{tabular}




\section{Acknowledgments}

The editors thank Dr. Jackie Richter-Menge (University of Alaska Fairbanks), who served as a senior editorial advisor for this chapter, drawing on her many years of experience as this chapter's lead editor. The editors also thank Florence Fetterer (National Snow and Ice Data Center) and Dr. John Walsh (International Arctic Research Center, University of Alaska Fairbanks) for providing an initial review of the full chapter. Their careful read and thoughtful input improved each of the sections and, importantly, led to better coherency between the sections.

\section{a. Overview}

- Matthew Druckenmiller and Twila Moon appreciate support from NOAA's Arctic Research Office.

\section{b. Surface air temperature}

- Thomas Ballinger was supported by the Experimental Arctic Prediction Initiative at the University of Alaska Fairbanks.

- Melinda Webster was supported by NASA's Weather and Atmospheric Dynamics program under 80NSSC20K0922.

\section{d. Sea ice}

- Walt Meier's contribution was supported by the NASA Snow and Ice Distributed Active Archive Center (DAAC) at NSIDC, part of the NASA Earth Science Data and Information System (ESDIS) Project.

\section{e. Greenland ice sheet}

- Data from the Programme for Monitoring of the Greenland Ice Sheet (PROMICE) were provided by the Geological Survey of Denmark and Greenland (GEUS) at http://www.promice.dk.

- Twila Moon was supported by the University of Colorado Boulder Cooperative Institute for Research in Environmental Sciences.

- Marco Tedesco was supported by National Science Foundation ANS \#1713072, National Science Foundation PLR-1603331, NASA MAP \#80NSSC17K0351, NASA \#NNX17AH04G, and the Heising-Simons foundation.

- Thomas Mote was supported by National Science Foundation \#1900324.

\section{g. River discharge}

- Max Holmes and coauthors acknowledge National Science Foundation support for the Arctic Great Rivers Observatory (NSF 1913888, 1914081, 1914215, 1913962).

- Shiklomanov and Tretiakov acknowledge support from the Russian Foundation for Basic Research (grants 18-05-60192 and 18-05-60240).

\section{i. Tundra greenness}

- The authors thank Jorge Pinzon at NASA's Goddard Space Flight Center for developing and maintaining the AVHRR GIMMS-3g+ dataset for NDVI. 


\section{j. Ozone and ultraviolet radiation}

- Germar Bernhard and coauthors acknowledge the support of Biospherical Instruments, San Diego; the Research Council of Norway through its Centres of Excellence funding scheme, project number 223268/ F50; the Academy of Finland for supporting UV measurements through the FARPOCC, SAARA, and CHAMPS (grant no. 329225) projects; the European Space Agency for supporting the DACES project; the Norwegian Environment Agency for funding UV measurements at Andøya and Ny-Ålesund; and the European Union for supporting e-shape. The authors also thank the Microwave Limb Sounder team at NASA's Jet Propulsion Laboratory for data-processing and analysis support, and Juha M. Karhu, Tomi Karppinen, and Markku Ahponen from the Finnish Meteorological Institute for operating the Brewer UV spectroradiometer at Sodankylä.

\section{Sidebar 5.1 Wildland fires in the high northern latitudes}

- The material is based upon work supported in part by the National Science Foundation award \#OIA1753748, by the State of Alaska, by the Joint Fire Science Program award \#20-3-01-1, by the NOAA Climate Program Office through Grant NA160AR4310162 with the Alaska Center for Climate Assessment and Policy at the University of Alaska at Fairbanks, and by the NASA Weather and Data Analysis program.

\section{Sidebar 5.2 Assessing 15 years of Arctic Observing Network contributions to tracking key Arctic climate variables}

- Hazel Shapiro was supported by the Interagency Arctic Research Policy Committee and the Arctic Research Consortium of the United States (NSF grant \#PLR-1928794).

- Sandy Starkweather appreciates support from NOAA's Arctic Research Program.

- All the authors appreciate the support of the subject matter experts who contributed their time and expertise, and the Arctic Data Center for their partnership in creating a searchable online catalog of the 2020 data products referenced in this study. 


\section{Chapter 5 - Acronyms}

\begin{tabular}{|c|c|}
\hline ALT & active layer thickness \\
\hline AON & Arctic Observing Network \\
\hline ARC & Arctic Report Card \\
\hline AVHRR & Advanced Very High Resolution radiometer \\
\hline AWS & automated weather stations \\
\hline BUI & Buildup Index \\
\hline CALM & Circumpolar Active Layer Monitoring \\
\hline CFFDRS & Canadian Forest Fire Danger Rating System \\
\hline CMC & Canadian Meteorological Centre \\
\hline DMI & Danish Meteorological Institute \\
\hline DU & Dobson units \\
\hline GIMMS-3g+ & Global Inventory Modeling and Mapping Studies 3g V1.2 \\
\hline GRACE & Gravity Recovery and Climate Experiment \\
\hline GRACE-FO & GRACE Follow-On \\
\hline HNL & high northern latitudes \\
\hline ICESat-2 & Ice, Cloud, and land Elevation 2 \\
\hline IMS & Interactive Multisensor Snow and Ice Mapping System \\
\hline MAR & Modèle Atmosphérique Régional \\
\hline MaxNDVI & maximum NDVI \\
\hline MCD43A4 & $\begin{array}{l}\text { Nadir Bidirectional Reflectance Distribution Function Adjusted } \\
\text { Reflectance }\end{array}$ \\
\hline MERRA-2 & $\begin{array}{l}\text { Modern-Era Retrospective Analysis for Research and } \\
\text { Applications version } 2\end{array}$ \\
\hline MLS & Microwave Limb Sounder \\
\hline MODIS & Moderate Resolution Imaging Spectroradiometer \\
\hline MOSAiC & $\begin{array}{l}\text { Multidisciplinary drifting Observatory for the Study of } \\
\text { Arctic Climate }\end{array}$ \\
\hline NDVI & Normalized Difference Vegetation Index \\
\hline $\mathrm{NH}$ & Northern Hemisphere \\
\hline NSIDC & National Snow and Ice Data Center \\
\hline OISSTV2 & Optimum Interpolation Sea Surface Temperature version 2 \\
\hline OMI & Ozone Monitoring Instrument \\
\hline OSI SAF CCI & $\begin{array}{l}\text { Ocean and Sea Ice Satellite Application Facility Climate } \\
\text { Change Initiative }\end{array}$ \\
\hline PM & Passive Microwave \\
\hline PROMICE & Programme for Monitoring of the Greenland Ice Sheet \\
\hline PSCs & polar stratospheric clouds \\
\hline SAT & surface air temperature \\
\hline SCD & snow cover duration \\
\hline SCE & snow cover extent \\
\hline SLP & sea-level pressure \\
\hline SMB & surface mass balance \\
\hline SMOS & Soil Moisture Ocean Salinity \\
\hline SPEI & Standardized Precipitation-Evapotranspiration Index \\
\hline SSMIS & Special Sensor Microwave Imager/Sounder \\
\hline
\end{tabular}


SSTS

SWE

TOC

UV

UVI

VTA sea surface temperatures

snow water equivalent

total ozone column

ultraviolet

ultraviolet index

value tree assessment 


\section{References}

Abramov, A., and Coauthors, 2021: Two decades of active layer thickness monitoring in northeastern Asia. Polar Geogr., https://doi.org/10.1080/108893 7X.2019.1648581, in press.

AICC, 2020: Alaska fire history data. Alaska Interagency Coordination Center, accessed 10 September 2020, https://fire.ak.blm.gov/predsvcs/intel.php.

Andersen, J. K., and Coauthors, 2019: Update of annual calving front lines for 47 marine terminating outlet glaciers in Greenland (1999-2018). Geol. Surv. Denmark Greenl. Bull., 43, e2019430202, https://doi.org/10.34194/ GEUSB-201943-02-02.

Andreu-Hayles, L., B. V. Gaglioti, L. T. Berner, M. Levesque, K. J. Anchukaitis, S. J. Goetz, and R. D'Arrigo, 2020: A narrow window of summer temperatures associated with shrub growth in Arctic Alaska. Environ. Res. Lett., 15, 105012, https://doi.org/10.1088/1748-9326/ab897f.

AOS EOC, 2018: Report of the 4th Arctic observing summit: AOS 2018, Davos, Switzerland, 24-26 June 2018. International Study of Arctic Change (ISAC) Program Office, Arctic Institute of North America, 17 pp., www.arcticobservingsummit.org/sites/default/files/Report\%20on\%20the\%20A0S\%202018_ FINAL_March2019_0.pdf.

Ballinger, T. J., and Coauthors, 2020: Surface air temperature. NOAA Arctic Report Card 2020, R. L. Thoman, J. Richter-Menge, and M. L. Druckenmiller, Eds., NOAA, https://doi.org/10.25923/gcw8-2z06.

Barrett, K., T. Loboda, A. D. McGuire, H. Genet, E. Hoy, and E. Kasischke, 2016: Static and dynamic controls on fire activity at moderate spatial and temporal scales in the Alaskan boreal forest. Ecosphere, 7, e01572, https://doi. org/10.1002/ecs2.1572.

Berner, L. T., and Coauthors, 2020: Summer warming explains widespread but not uniform greening in the Arctic tundra biome. Nat. Commun., 11, 4621, https:// doi.org/10.1038/s41467-020-18479-5.

Bernhard, G., and Coauthors, 2020: Record-breaking increases in Arctic solar ultraviolet radiation caused by exceptionally large ozone depletion in 2020. Geophys. Res. Lett., 47, e2020GL090844, https://doi.org/10.1029/2020GL090844.

Bhartia, P. K., and C. W. Wellemeyer, 2002: TOMS-V8 total 03 algorithm. OMI Algorithm Theoretical Basis Document Volume II, NASA Goddard Space Flight Center Tech. Doc. ATBD-0MI-02, 15-31, http://eospso.nasa.gov/sites/default/ files/atbd/ATBD-OMI-02.pdf.

Bhatt, U. S., and Coauthors, 2010: Circumpolar Arctic tundra vegetation change is linked to sea ice decline. Earth Interact., 14, https://doi. org/10.1175/2010EI315.1.

— central Alaska temperature and precipitation extremes and related fires in 2019. Land, 10, 82, https://doi.org/10.3390/land10010082.

Bieniek, P. A., and Coauthors, 2020: Lightning variability in dynamically downscaled simulations of Alaska's present and future summer climate. J. Appl. Meteor. Climatol., 59, 1139-1152, https://doi.org/10.1175/JAMC-D-19-0209.1.

Biskaborn, B. K., and Coauthors, 2019: Permafrost is warming at a global scale. Nat. Commun., 10, 264, https://doi.org/10.1038/s41467-018-08240-4.

Bjella, K., 2019: Warming and thawing permafrost and impacts on infrastructure [in "State of the Climate in 2018"]. Bull. Amer. Meteor. Soc., 100 (9), S157S159, 10.1175/2019BAMSStateoftheClimate.1.

Bjorkman, A. D., and Coauthors, 2020: Status and trends in Arctic vegetation: Evidence from experimental warming and long-term monitoring. Ambio, 49, 678-692, https://doi.org/10.1007/s13280-019-01161-6.

Boike, J., and Coauthors, 2018: A 20-year record (1998-2017) of permafrost, active layer, and meteorological conditions at a high Arctic permafrost research site (Bayelva, Spitsbergen). Earth Syst. Sci. Data, 10, 355-390, https://doi. org/10.5194/essd-10-355-2018.

Box, J. E., D. van As, and K. Steffen, 2017: Greenland, Canadian and Icelandic land ice albedo grids (2000-2016). Geol. Surv. Denmark Greenl. Bull., 38, 53-56, https://doi.org/10.34194/geusb.v38.4414.

_ - and Coauthors, 2019: Key indicators of Arctic climate change: 1971-2017. Environ. Res. Lett., 14, 045010, https://doi.org/10.1088/1748-9326/aafc1b.
Brasnett, B., 1999: A global analysis of snow depth for numerical weather prediction. J. Appl. Meteor., 38, 726-740, https://doi.org/10.1175/15200450(1999)038<0726:AGAOSD>2.0.C0;2.

Brown, J., O. J. Ferrians Jr., J. A. Heginbottom, and E. S. Melnikov, 1997: CircumArctic map of permafrost and ground-ice conditions. U.S. Geological Survey Circum-Pacific Map CP-45, https://doi.org/10.3133/cp45.

Brown, R. D., and B. Brasnett, 2010: Canadian Meteorological Centre (CMC) Daily Snow Depth Analysis Data, Version 1. NASA National Snow and Ice Data Center Distributed Active Archive Center, accessed 27 July 2020, https://doi. org/10.5067/W9FOYWH0EQZ3.

_ B. Brasnett, and D. Robinson, 2003: Gridded North American monthly snow depth and snow water equivalent for GCM evaluation. Atmos.-Ocean, 41, 1-14, https://doi.org/10.3137/ao.410101.

— , D. Vikhamar Schuler, O. Bulygina, C. Derksen, K. Luojus, L. Mudryk, L. Wang, and D. Yang, 2017: Arctic terrestrial snow cover. Snow, Water, Ice and Permafrost in the Arctic (SWIPA) 2017, Arctic Monitoring and Assessment Programme, 25-64.

Brun, E., V. Vionnet, A. Boone, B. Decharme, Y. Peings, R. Valette, F. Karbou, and S. Morin, 2013: Simulation of Northern Eurasian local snow depth, mass, and density using a detailed snowpack model and meteorological reanalyses. J. Hydrometeor., 14, 203-219, https://doi.org/10.1175/JHM-D-12-012.1.

Buchwal, A., and Coauthors, 2020: Divergence of Arctic shrub growth associated with sea ice decline. Proc. Natl. Acad. Sci. USA, 117, 33334-33344, https:// doi.org/10.1073/pnas.2013311117.

Butchart, N., and E. E. Remsberg, 1986: The area of the stratospheric polar vortex as a diagnostic for tracer transport on an isentropic surface. J. Atmos. Sci., 43, 1319-1339, https://doi.org/10.1175/1520-0469(1986)043<1319:TAOTS $\mathrm{P}>2.0 . \mathrm{CO} ; 2$

Callaghan, T., and Coauthors, 2011: The changing face of Arctic snow cover: A synthesis of observed and projected changes. Ambio, 40, 17-31, https://doi. org/10.1007/s13280-011-0212-y.

Chen, Y., F. S. Hu, and M. J. Lara, 2021: Divergent shrub-cover responses driven by climate, wildfire, and permafrost interactions in Arctic tundra ecosystems. Global Change Biol., 27, 652-663, https://doi.org/10.1111/gcb.15451.

Christiansen, H., and Coauthors, 2010: The thermal state of permafrost in the Nordic area during the International Polar Year 2007-2009. Permafrost Periglacial Processes, 21, 156-181, https://doi.org/10.1002/ppp.687.

Cohen, J., and Coauthors, 2020: Divergent consensuses on Arctic amplification influence on mid-latitude severe winter weather. Nat. Climate Change, 10, 20-29, https://doi.org/10.1038/s41558-019-0662-y.

DeLand, M. T., P. K. Bhartia, N. Kramarova, and Z. Chen, 2020: OMPS LP observations of PSC variability during the NH 2019-2020 season. Geophys. Res. Lett., 47, e2020GL090216, https://doi.org/10.1029/2020GL090216.

Ednie, M., and S. L. Smith, 2015: Permafrost temperature data 2008-2014 from community based monitoring sites in Nunavut. Geological Survey of Canada Open File 7784, 18 pp., https://doi.org/10.4095/296705.

EEAP, 2019: Environmental Effects and Interactions of Stratospheric Ozone Depletion, UV Radiation, and Climate Change: 2018 Assessment Report. Environmental Effects Assessment Panel, United Nations Environment Programme, $390 \mathrm{pp}$. https://ozone.unep.org/sites/default/files/2019-04/EEAP _assessment-report-2018\%20\%282\%29.pdf.

Epstein, H. E., and Coauthors, 2021: Spatial patterns of arctic tundra vegetation properties on different soils along the Eurasia Arctic Transect, and insights for a changing Arctic. Environ. Res. Lett., 16, 014008, https://doi. org/10.1088/1748-9326/abc9e3.

Estilow, T. W., A. H. Young, and D. A. Robinson, 2015: A long-term Northern Hemisphere snow cover extent data record for climate studies and monitoring. Earth Syst. Sci. Data, 7, 137-142, https://doi.org/10.5194/essd-7-137-2015.

Etzelmüller, B., and Coauthors, 2020: Twenty years of European mountain permafrost dynamics-The PACE legacy. Environ. Res. Lett., 15, 104070, https://doi. org/10.1088/1748-9326/abae9d. 
Fausto, R.S. and D. van As, 2019: Programme for monitoring of the Greenland Ice Sheet (PROMICE): Automatic weather station data, version: v03. Geological Survey of Denmark and Greenland, accessed 14 September 2020, https://doi. org/10.22008/promice/data/aws.

Fetterer, F., K. Knowles, W. N. Meier, M. Savoie, and A. K. Windnagel, 2017: Sea Ice Index, Version 3. Subset: Regional Daily Data (updated daily), National Snow and Ice Data Center, accessed 15 February 2021, https://doi.org/10.7265/ N5K072F8.

Flannigan, M., B. Stocks, M. Turetsky, and M. Wotton, 2009: Impacts of climate change on fire activity and fire management in the circumboreal forest. Global Change Biol., 15, 549-560, https://doi.org/10.1111/j.13652486.2008.01660.x.

Frederikse, T., and Coauthors, 2020: The causes of sea-level rise since 1900. Nature, 584, 393-397, https://doi.org/10.1038/s41586-020-2591-3.

Gearheard, S., L. K. Holm, H. Huntington, J. M. Leavitt, and A. R. Mahoney, Eds., 2013: The Meaning of Ice: People and Sea Ice in Three Arctic Communities. International Polar Institute, $336 \mathrm{pp}$.

Gelaro, R., and Coauthors, 2017: The Modern-Era Retrospective Analysis for Research and Applications, version 2 (MERRA-2). J. Climate, 30, 5419-5454, https://doi.org/10.1175/JCLI-D-16-0758.1.

Giglio, L., L. Boschetti, D. P. Roy, M. L. Humber, and C. O. Justice, 2018: The Collection 6 MODIS burned area mapping algorithm and product. Remote Sens. Environ., 217, 72-85, https://doi.org/10.1016/j.rse.2018.08.005.

GMA0, 2015: MERRA-2tavg1_2d_Ind_Nx:2d, 1-Hourly, Time-Averaged, SingleLevel, Assimilation, Land Surface Diagnostics V5.12.4. Goddard Earth Sciences Data and Information Services Center, accessed 26 August 2020, https:// doi.org/10.5067/RKPHT8KC1Y1T.

Hanes, C. C., X. Wang, P. Jain, M. A. Parisien, J. M. Little, and M. D. Flannigan, 2019: Fire-regime changes in Canada over the last half century. Can. J. For. Res., 49, 256-269, https://doi.org/10.1139/cjfr-2018-0293.

Hanna, E., and Coauthors, 2020: Mass balance of the ice sheets and glaciersProgress since AR5 and challenges. Earth-Sci. Rev., 201, 102976, https://doi. org/10.1016/j.earscirev.2019.102976.

Hayasaka, H., H. L. Tanaka, and P. A. Bieniek, 2016: Synoptic-scale fire weather conditions in Alaska. Polar Sci., 10, 217-226, https://doi.org/10.1016/j.polar 2016.05.001.

Heim, R. J., A. Bucharova, L. Brodt, J. Kamp, D. Rieker, A. V. Soromotin, A. Yurtaev, and N. Hölzel, 2021: Post-fire vegetation succession in the Siberian subarctic tundra over 45 years. Sci. Total Environ., 760, 143425, https://doi. org/10.1016/j.scitotenv.2020.143425.

Helfrich, S., D. McNamara, B. Ramsay, T. Baldwin, and T. Kasheta, 2007: Enhancements to, and forthcoming developments in the Interactive Multisensor Snow and Ice Mapping System (IMS). Hydrol. Processes, 21, 1576-1586, https://doi. org/10.1002/hyp.6720.

Hersbach, H., and Coauthors, 2020: The ERA5 global reanalysis. Quart. J. Roy. Meteor. Soc., 146, 1999-2049, https://doi.org/10.1002/qj.3803.

Holmes, R. M., and Coauthors, 2013: Climate change impacts on the hydrology and biogeochemistry of Arctic rivers. Global Impacts of Climate Change on Inland Waters, C. R. Goldman, M. Kumagai, and R. D. Robarts, Eds., Wiley, 3-26.

IDA, 2017: International Arctic Observations Assessment Framework. IDA Science and Technology Policy Institute, 73 pp., www.arcticobserving.org/news/268international-arctic-observations-assessment-framework-released.

Isaksen, K., and Coauthors, 2011: Degrading mountain permafrost in southern Norway: Spatial and temporal variability of mean ground temperatures, 1999-2009. Permafrost Periglacial Processes, 22, 361-377, https://doi. org/10.1002/ppp.728.

Jones, P. D., D. H. Lister, T. J. Osborn, C. Harpham, M. Salmon, and C. P. Morice, 2012: Hemispheric and large-scale land-surface air temperature variations: An extensive revision and an update to 2010. J. Geophys. Res., 117, D05127, https://doi.org/10.1029/2011JD017139.

Kalnay, E., and Coauthors, 1996: The NCEP/NCAR 40-Year Reanalysis Project. Bull. Amer. Meteor. Soc., 77, 437-471, https://doi.org/10.1175/15200477(1996)077<0437:TNYRP>2.0.CO;2.
Kemppinen, J., P. Niittynen, A.-M. Virkkala, K. Happonen, H. Riihimäki, J. Aalto, and M. Luoto, 2021: Dwarf shrubs impact tundra soils: Drier, colder, and less organic carbon. Ecosystems, https://doi.org/10.1007/s10021-020-00589-2, in press.

Kopec, B., X. Feng, F. A. Michel, and E. Posmentier, 2016: Influence of sea ice on Arctic precipitation. Proc. Natl. Acad. Sci. USA, 113, 46-51, https://doi. org/10.1073/pnas.1504633113.

Kropp, H., and Coauthors, 2021: Shallow soils are warmer under trees and tall shrubs across Arctic and boreal ecosystems. Environ. Res. Lett., 16, 015001, https://doi.org/10.1088/1748-9326/abc994.

Landrum, L., and M. M. Holland, 2020: Extremes become routine in an emerging new Arctic. Nat. Climate Change, 10, 1108-1115, https://doi.org/10.1038/ s41558-020-0892-z.

Lavergne, T., and Coauthors, 2019: Version 2 of the EUMETSAT OSI SAF and ESA CCI sea-ice concentration climate data records. Cryosphere, 13, 49-78, https://doi.org/10.5194/tc-13-49-2019.

Lawrence, D. M., A. G. Slater, R. A. Tomas, M. M. Holland, and C. Deser, 2008:Accelerated Arctic land warming and permafrost degradation during rapid sea ice loss. Geophys. Res. Lett., 35, L11506, https://doi.org/10.1029/2008GL033985.

Lawrence, Z. D., J. Perlwitz, A. H. Butler, G. L. Manney, P. A. Newman, S.H. Lee, and E. R. Nash, 2020: The remarkably strong Arctic stratospheric polar vortex of winter 2020: Links to record-breaking Arctic oscillation and ozone loss. J. Geophys Res. Atmos., 125, e2020JD033271, https://doi.org/10.1029/2020JD033271.

Lee, C. M., and Coauthors, 2019: A framework for the development, design and implementation of a sustained Arctic ocean observing system. Front. Mar. Sci., 6, 451, https://doi.org/10.3389/fmars.2019.00451.

Liljedahl, A. K., I. Timling, G. V. Frost, and R. P. Daanen, 2020: Arctic riparian shrub expansion indicates a shift from streams gaining water to those that lose flow. Commun. Earth Environ., 1, 50, https://doi.org/10.1038/s43247-02000050-1.

Lund, M., K. Raundrup, A. Westergaard-Nielsen, E. López-Blanco, J. Nymand, and P. Aastrup, 2017: Larval outbreaks in West Greenland: Instant and subsequent effects on tundra ecosystem productivity and $\mathrm{CO} 2$ exchange. Ambio, 46, 26-38, https://doi.org/10.1007/s13280-016-0863-9.

Mankoff, K. D., A. Solgaard, W. Colgan, A. P. Ahlstrøm, S. A. Khan, and R. S. Fausto, 2020: Greenland ice sheet solid ice discharge from 1986 through March 2020. Earth Syst. Sci. Data, 12, 1367-1383, https://doi.org/10.5194/essd-121367-2020.

Manney, G. L., and Z. D. Lawrence, 2016: The major stratospheric final warming in 2016: Dispersal of vortex air and termination of Arctic chemical ozone loss. Atmos. Chem. Phys., 16, 15371-15396, https://doi.org/10.5194/acp-1615371-2016.

Manney, G. L., and Coauthors, 2020: Record-low Arctic stratospheric ozone in 2020: MLS observations of chemical processes and comparisons with previous extreme winters, Geophys. Res. Lett., 47, e2020GL089063, https://doi. org/10.1029/2020GL089063.

McClelland, J. W., S. J. Deiry, B. J. Peterson, R. M. Holmes, and E. F. Wood, 2006: A pan-arctic evaluation of changes in river discharge during the latter half of the 20th century. Geophys. Res. Lett., 33, L06715, https://doi. org/10.1029/2006GL025753.

— , R. M. Holmes, K. H. Dunton, and R. Macdonald, 2012: The Arctic Ocean estuary. Estuaries Coasts, 35, 353-368, https://doi.org/10.1007/s12237-0109357-3.

McElhinny, M., J. F., Beckers, C. Hanes, M. Flannigan, and P. Jain, 2020: A highresolution reanalysis of global fire weather from 1979 to 2018-Overwintering the drought code. Earth Syst. Sci. Data, 12, 1823-1833, https://doi. org/10.5194/essd-2019-248.

Meier, W., J. Stroeve, and F. Fetterer, 2007: Whither Arctic sea ice? A clear signal of decline regionally, seasonally and extending beyond the satellite record. Ann. Glaciol., 46, 428-434, https://doi.org/10.3189/172756407782871170. 
- F. Fetterer, M. Savoie, S. Mallory, R. Duerr, and J. Stroeve, 2017: NOAA/ NSIDC Climate Data Record of Passive Microwave Sea Ice Concentration, Version 3. National Snow and Ice Data Center, accessed 1 January 2020, https:// doi.org/10.7265/N59P2ZTG.

Moon, T. A., and Coauthors, 2019: The expanding footprint of rapid Arctic change. Earth's Future, 7, 212-218, https://doi.org/10.1029/2018EF001088.

Morlighem, M., and Coauthors, 2017: BedMachine v3: Complete bed topography and ocean bathymetry mapping of Greenland from multibeam echo sounding combined with mass conservation. Geophys. Res. Lett., 44, 11 051-11 061, https://doi.org/10.1002/2017GL074954.

Mote, T., 2007: Greenland surface melt trends 1973-2007: Evidence of a large increase in 2007. Geophys. Res. Lett., 34, L22507, https://doi. org/10.1029/2007GL031976.

Mouginot, J., and Coauthors, 2019: Forty-six years of Greenland ice sheet mass balance from 1972 to 2018. Proc. Natl. Acad. Sci. USA, 116, 9239-9244, https://doi.org/10.1073/pnas.1904242116.

Mudryk, L., M. Santolaria-Otín, G. Krinner, M. Ménégoz, C. Derksen, C. Brutel-Vuilmet, M. Brady, and R. Essery, 2020a: Historical Northern Hemisphere snow cover trends and projected changes in the CMIP-6 multi-model ensemble. Cryosphere, 14, 2495-2514, https://doi.org/10.5194/tc-14-2495-2020.

_, R. Brown, C. Derksen, K. Luojus, and B. Decharme, 2020b: Terrestrial snow cover [in "State of the Climate in 2019"]. Bull. Amer. Meteor. Soc., 101 (8), S263-S265, https://doi.org/10.1175/BAMS-D-20-0086.1.

Müller, R., J.-U. Grooß, C. Lemmen, D. Heinze, M. Dameris, and G. Bodeker, 2008: Simple measures of ozone depletion in the polar stratosphere. Atmos. Chem. Phys., 8, 251-264, https://doi.org/10.5194/acp-8-251-2008.

Murray, M. S., R. D. Sankar, and G. Ibarguchi, 2018: The Arctic observing summit, background and synthesis of outcomes 2013-2016. International Study of Arctic Change Program Office, Arctic Institute of North America, 8 pp., www. arcticobservingsummit.org/sites/default/files/AOS_Synthesis_FinalReport. pdf.

Myers-Smith, I. H., and Coauthors, 2020: Complexity revealed in the greening of the Arctic. Nat. Climate Change, 10, 106-117, https://doi.org/10.1038/ s41558-019-0688-1.

NRC, 2006: Toward an Integrated Arctic Observing Network. The National Academies Press, 128 pp., https://doi.org/10.17226/11607.

Neale, R. E., and Coauthors, 2021: Environmental effects of stratospheric ozone depletion, UV radiation, and interactions with climate: UNEP Environmental Effects Assessment Panel, Update 2020. Photochem. Photobiol. Sci., 20, 1-67, https://doi.org/10.1007/s43630-020-00001-x.

OSTP, 2014: National Plan for Civil Earth Observations. National Science and Technology Council, 71 pp., https://obamawhitehouse.archives.gov/sites/ default/files/microsites/ostp/NSTC/2014_national_plan_for_civil_earth_observations.pdf.

Overland, J. E., and M. Wang, 2021: The 2020 Siberian heat wave. Int. J. Climatol., 41, E2341-E2346, https://doi.org/10.1002/joc.6850.

— obfuscate the Arctic influence on midlatitude winter extreme weather events? Environ. Res. Lett., 16, 043002, https://doi.org/10.1088/1748-9326/abdb5d.

Partain, J. L., and Coauthors, 2016: An assessment of the role of anthropogenic climate change in the Alaska fire season of 2015 [in "Explaining Extremes of 2015 from a Climate Perspective"]. Bull. Amer. Meteor. Soc., 97 (12), S14S18, https://doi.org/10.1175/BAMS-D-16-0149.1.

Peltier, W. R., D. F. Argus, and R. Drummond, 2018: Comment on "An assessment of the ICE-6G_C (VM5a) glacial isostatic adjustment model" by Purcell et al. J. Geophys. Res. Solid Earth, 123, 2019-2018, https://doi. org/10.1002/2016JB013844.

Peng, G., W. N. Meier, D. J. Scott, and M. H. Savoie, 2013: A long-term and reproducible passive microwave sea ice concentration data record for climate studies and monitoring. Earth Syst. Sci. Data, 5, 311-318, https://doi.org/10.5194/ essd-5-311-2013.
Peterson, B. J., R. M. Holmes, J. W. McClelland, C. J. Vorosmarty, R. B. Lammers, A. I. Shiklomanov, I. A. Shiklomanov, and S. Rahmstorf, 2002: Increasing river discharge to the Arctic Ocean. Science, 298, 2171-2173, https://doi. org/10.1126/science.1077445.

Petty, A. A., M. Webster, L. Boisvert, and T. Markus, 2018: The NASA Eulerian Snow on Sea Ice Model (NESOSIM) v1.0: Initial model development and analysis. Geosci. Model Dev., 11, 4577-4602, https://doi.org/10.5194/gmd-11-45772018.

— N. T. Kurtz, R. Kwok, T. Markus, T. A. Neumann, 2020. Winter Arctic sea ice thickness from ICESat-2 freeboards. J. Geophys. Res. Oceans, 125, e2019JC015764. https://doi.org/10.1029/2019JC015764.

Pinzon, J., and C. Tucker, 2014: A non-stationary 1981-2012 AVHRR NDVI3g time series. Remote Sens., 6, 6929-6960, https://doi.org/10.3390/rs6086929.

Prendin, A. L., and Coauthors, 2020: Immediate and carry-over effects of insect outbreaks on vegetation growth in West Greenland assessed from cells to satellite. J. Biogeogr., 47, 87-100, https://doi.org/10.1111/jbi.13644.

Rawlins, M. A., and Coauthors, 2010: Analysis of the arctic system freshwater cycle intensification: observations and expectations. J. Climate, 23, 5715-5737, https://doi.org/10.1175/2010JCLI3421.1.

Raynolds, M. K., D. A. Walker, H. E. Epstein, J. E. Pinzon, and C. J. Tucker, 2012: A new estimate of tundra-biome phytomass from trans-Arctic field data and AVHRR NDVI. Remote Sens. Lett., 3, 403-411, https://doi.org/10.1080/0143 1161.2011.609188.

Reynolds, R. W., N. A. Rayner, T. M. Smith, D. C. Stokes, and W. Wang, 2002: An improved in situ and satellite SST analysis for climate. J. Climate, 15, 16091625, https://doi.org/10.1175/1520-0442(2002)015<1609:AllSAS>2.0.C0;2.

, T. M. Smith, C. Liu, D. B. Chelton, K. S. Casey, and M. G. Schlax, 2007: Daily high-resolution-blended analyses for sea surface temperature. J. Climate, 20, 5473-5496, https://doi.org/10.1175/2007JCLI1824.1.

Ricker, R., S. Hendricks, L. Kaleschke, X. Tian-Kunze, J. King, and C. Haas, 2017: A weekly Arctic sea-ice thickness data record from merged CryoSat-2 and SMOS satellite data. Cryosphere, 11, 1607-1623, https://doi.org/10.5194/tc11-1607-2017.

Robinson, D. A., T. W. Estilow, and NOAA CDR Program, 2012: NOAA Climate Data Record (CDR) of Northern Hemisphere (NH) Snow Cover Extent (SCE), Version 1 [r01]. NOAA National Centers for Environmental Information, accessed 27 July 2020, https://doi.org/10.7289/V5N014G9.

Romanovsky, V., and Coauthors, 2017: Changing permafrost and its impacts. Snow, Water, Ice and Permafrost in the Arctic (SWIPA) 2017, Arctic Monitoring and Assessment Programme, 65-102.

_ 2019"]. Bull. Amer. Meteor. Soc., 101(8), S265-S269, https://doi.org/10.1175/ BAMS-D-20-0086.1

Sasgen, I., and Coauthors, 2020: Return to rapid ice loss in Greenland and record loss in 2019 detected by the GRACE-FO satellites. Commun. Earth. Environ., 1, 8, https://doi.org/10.1038/s43247-020-0010-1.

Schaaf, C. B., and Z. Wang, 2015: MCD43A4 MODIS/Terra+Aqua BRDF/Albedo Nadir BRDF Adjusted Ref Daily L3 Global - 500m V006. NASA EOSDIS Land Processes DAAC, accessed 21 February 2021, https://doi.org/10.5067/MODIS/ MCD43A4.006.

Scholten, R., R. Jandt, E. A. Miller, B. M. Rogers, and S. Veraverbeke, 2021: Overwintering fires in boreal forests. Nature, 593, 399-404, https://doi.org/10.1038/ s41586-021-03437-y.

Schroeder, W., P. Oliva, L. Giglio, and I. A. Csiszar, 2014: The new VIIRS 375m active fire detection data product: Algorithm description and initial assessment. Remote Sens. Environ., 143, 85-96, https://doi.org/10.1016/j.rse.2013.12.008.

Schuur, E. A. G., 2020: Permafrost carbon [in "State of the Climate in 2019"]. Bull. Amer. Meteor. Soc., 101 (8), S270-S271, https://doi.org/10.1175/BAMSD-20-0086.1.

Serreze, M. C., and R. G. Barry, 2011: Processes and impacts of Arctic amplification: A research synthesis. Global Planet. Change, 77, 85-96, https://doi. org/10.1016/j.gloplacha.2011.03.004. 
Shevtsova, I., B. Heim, S. Kruse, J. Schröder, E. I. Troeva, L. A. Pestryakova, E. S. Zakharov, and U. Herzschuh, 2020: Strong shrub expansion in tundra-taiga, tree infilling in taiga and stable tundra in central Chukotka (north-eastern Siberia) between 2000 and 2017. Environ. Res. Lett., 15, 085006, https://doi. org/10.1088/1748-9326/ab9059.

Shiklomanov, N. I., D. A. Streletskiy, and F. E. Nelson, 2012: Northern Hemisphere component of the global Circumpolar Active Layer Monitoring (CALM) program. Proc. 10th Int. Conf. on Permafrost, Vol. 1, Salekhard, Russia, Tyumen Oil and Gas University, 377-382.

Shiklomanov, A. I., S. J. Deiry, M. V. Tretiakov, D. Yang, D. Magritsky, A. Georgiadi, and W. Tang, 2021: River freshwater flux to the Arctic Ocean. Arctic Hydrology, Permafrost and Ecosystem, Y. Daqing and K. Douglas, Eds., Springer, 703-738.

Shupe, M. D., and Coauthors, 2020: The MOSAiC expedition: A year drifting with the Arctic sea ice. NOAA Arctic Report Card 2020, R.L. Thoman, J. RichterMenge, and M. L. Druckenmiller, Eds., NOAA, https://doi.org/10.25923/9g3vxh92.

Simonsen, S. B., V. R. Barletta, W. T. Colgan, and L. S. Sørensen, 2021: Greenland Ice Sheet mass balance (1992-2020) from calibrated radar altimetry. Geophys. Res. Lett., 48, 105-110, https://doi.org/10.1029/2020GL091216.

Skarin, A., M. Verdonen, T. Kumpula, M. Macias-Fauria, M. Alam, J. T. Kerby, and B. C. Forbes, 2020: Reindeer use of low Arctic tundra correlates with landscape structure. Environ. Res. Lett., 15, 115012, https://doi.org/10.1088/17489326/abbf15.

Slats, R., and Coauthors, 2019: Voices from the front lines of a Changing Bering Sea: An indigenous perspective for the 2019 Arctic Report Card. Arctic Report Card 2019, J. Richter-Menge, M. L. Druckenmiller, and M. Jeffries, Eds., NOAA, www.arctic.noaa.gov/Report-Card/Report-Card-2019.

Smith, S. L., C. Duchesne, and A. G. Lewkowicz, 2019: Tracking changes in permafrost thermal state in Northern Canada. Cold Regions Engineering 2019, J.-P. Bilodeau et al., Eds., American Society of Civil Engineers, 670-677, https://doi. org/10.1061/9780784482599.077.

Strand, S., H. Christiansen, M. Johansson, J. Akerman, and O. Humlum, 2020: Active layer thickening and controls on interannual variability in the Nordic Arctic compared to the circum-Arctic. Permafrost Periglacial Processes, 32, 47-58, https://doi.org/10.1002/ppp.2088.

Stroeve, J., and D. Notz, 2018: Changing state of Arctic sea ice across all seasons. Environ. Res. Lett., 13, 1-23, https://doi.org/10.1088/1748-9326/aade56.

Stroh, J. N., G. Panteleev, S. Kirillov, M. Makhotin, and N. Shakhova, 2015: Seasurface temperature and salinity product comparison against external in situ data in the Arctic Ocean. J. Geophys. Res. Oceans, 120, 7223-7236, https:// doi.org/10.1002/2015JC011005.

Swanson, D. K., 2021: Permafrost thaw-related slope failures in Alaska's Arctic National Parks, c. 1980-2019. Permafrost Periglacial Processes, https://doi. org/10.1002/ppp.2098, in press.

Takala, M., K. Luojus, J. Pulliainen, C. Derksen, J. Lemmetyinen, J.-P. Kärnä, and J. Koskinen, 2011: Estimating northern hemisphere snow water equivalent for climate research through assimilation of space-borne radiometer data and ground-based measurements. Remote Sens. Environ., 115, 3517-3529, https://doi.org/10.1016/j.rse.2011.08.014.

Tedesco, M., X. Fettweis, T. Mote, J. Wahr, P. Alexander, J. Box, and B. Wouters, 2013: Evidence and analysis of 2012 Greenland records from spaceborne observations, a regional climate model and reanalysis data. Cryosphere, 7, 615-630, https://doi.org/10.5194/tc-7-615-2013.

The IMBIE Team, 2020: Mass balance of the Greenland Ice Sheet from 1992 to 2018. Nature, 579, 233-239, https://doi.org/10.1038/s41586-019-1855-2.

Thoman, R. L., J. Richter-Menge, and M. L. Druckenmiller, Eds., 2020: Arctic Report Card 2020. NOAA, 143 pp., https://doi.org/10.25923/mn5p-t549.

Timmermans, M.-L., Z. Labe, and C. Ladd, 2020: Sea surface temperature [in "State of the Climate in 2019"]. Bull. Amer. Meteor. Soc., 101 (8), S249-S251, https://doi.org/10.1175/BAMS-D-20-0086.1.
Treharne, R., J. W. Bjerke, H. Tømmervik, and G. K. Phoenix, 2020: Extreme event impacts on $\mathrm{CO} 2$ fluxes across a range of high latitude, shrub-dominated ecosystems. Environ. Res. Lett., 15, 104084, https://doi.org/10.1088/1748-9326 labb0b1.

Tschudi, M., W. N. Meier, J. S. Stewart, C. Fowler, and J. Maslanik, 2019: EASE-Grid Sea Ice Age, Version 4. NASA National Snow and Ice Data Center Distributed Active Archive Center, accessed 15 February 2021, https://doi.org/10.5067/ UTAV7490FEPB.

$\longrightarrow,-$, and -2020 : An enhancement to sea ice motion and age products at the National Snow and Ice Data Center (NSIDC). Cryosphere, 14, 1519-1536, https://doi.org/10.5194/tc-14-1519-2020.

USGS, 2019: Demonstrating the Value of Earth Observations-Methods, Practical Applications, and Solutions-Group on Earth Observations Side Event Proceedings. USGS Open-File Rep. 2019-1033, 33 pp., https://pubs.usgs.gov/ of/2019/1033/ofr20191033.pdf.

U.S. National Ice Center, 2008: IMS Daily Northern Hemisphere Snow and Ice Analysis at 1 km, 4 km, and 24 km Resolutions, Version 1. National Snow and Ice Data Center, accessed 27 July 2020, https://doi.org/10.7265/N52R3PMC. .

van As, D., R. S. Fausto, J. Cappelen, R. S. van de Wal, R. J. Braithwaite, and H. Machguth, 2016: Placing Greenland ice sheet ablation measurements in a multi-decadal context. Geol. Surv. Denmark Greenl. Bull., 35, 71-74, https:// doi.org/10.34194/geusb.v35.4942.

Vasiliev, A. A., D. S. Drozdov, A. G. Gravis, G. V. Malkova, K. E. Nyland, and D. A. Streletskiy, 2020: Permafrost degradation in the western Russian Arctic. Environ. Res. Lett., 15, 045001, https://doi.org/10.1088/1748-9326/ab6f12.

Veraverbeke, S., B. M. Rogers, M. L. Goulden, R. R. Jandt, C. E. Miller, E. B. Wiggins, and J. T. Randerson, 2017: Lightning as a major driver of recent large fire years in North American boreal forests. Nat. Climate Change, 7, 529534, https://doi. org/10.1038/nclimate3329.

Verdonen, M., L. T. Berner, B. C. Forbes, and T. Kumpula, 2020: Periglacial vegetation dynamics in Arctic Russia: decadal analysis of tundra regeneration on landslides with time series satellite imagery. Environ. Res. Lett., 15, 105020, https://doi.org/10.1088/1748-9326/abb500.

Vickers, H., K. A. Høgda, S. Solbø, S. R. Karlsen, H. Tømmervik, R. Aanes, and B. B. Hansen, 2016: Changes in greening in the high Arctic: insights from a 30 year AVHRR max NDVI dataset for Svalbard. Environ. Res. Lett., 11, 105004, https://doi.org/10.1088/1748-9326/11/10/105004.

_, S. R. Karlsen, and E. Malnes, 2020: A 20-year MODIS-based snow cover dataset for Svalbard and its link to phenological timing and sea ice variability. Remote Sens., 12, 1123, https://doi.org/10.3390/rs12071123.

Vihma, T., and Coauthors, 2016: The atmospheric role in the Arctic water cycle: A review on processes, past and future changes, and their impacts. J. Geophys. Res. Biogeosci., 121, 586-620, https://doi.org/10.1002/2015JG003132.

Weatherhead, B., A. Tanskanen, and A. Stevermer, 2005: Ozone and ultraviolet radiation. Arctic Climate Impact Assessment, Cambridge University Press, 152-182, www.amap.no/documents/download/1086/inline.

Webster, M. A., C. Parker, L. Boisvert, and R. Kwok, 2019: The role of cyclone activity in snow accumulation on Arctic sea ice. Nat. Commun., 10, 5285, https:// doi.org/10.1038/s41467-019-13299-8.

Wegmann, M., and Coauthors, 2015: Arctic moisture source for Eurasian snow cover variations in autumn. Environ. Res. Lett., 10, 054015, https://doi. org/10.1088/1748-9326/10/5/054015.

Wheeling, K., 2020: The rise of zombie fires. Eos, 101, https://doi.org/10.1029 12020 E0146119.

WHO, 2002: Global solar UV index: A practical guide. WHO/SDE/OEH/02.2, 28 pp., www.who.int/uv/publications/en/GlobalUVI.pdf.

WMO, 2018: Scientific Assessment of Ozone Depletion: 2018. World Meteorological Organization, Global Ozone Research and Monitoring Project Rep. 58, 588 pp., https://csl.noaa.gov/assessments/ozone/2018/.

Wotton, B. M., 2009: Interpreting and using outputs from the Canadian forest fire danger rating system in research applications. Environ. Ecol. Stat., 16, 107-131, https://doi.org/10.1007/s10651-007-0084-2. 
Wu, W., X. Sun, H. Epstein, X. Xu, and X. Li, 2020: Spatial heterogeneity of climate variation and vegetation response for Arctic and high-elevation regions from 2001-2018. Environ. Res. Commun., 2, 011007, https://doi.org/10.1088/25157620/ab6369.

York, A., U. S. Bhatt, E. Gargulinski, Z. Grabinski, P. Jain, A. Soja, R. L. Thoman, and R. Ziel, 2020:Wildland fire in high Northern latitudes. Arctic Report Card 2020, R. L. Thoman, J. Richter-Menge, and M. L. Druckenmiller, Eds., NOAA, https:// doi.org/10.25923/2gef-3964.

Young, A. M., P. E. Higuera, P. A. Duffy, and F. S. Hu, 2017: Climatic thresholds shape northern highlatitude fire regimes and imply vulnerability to future climate change. Ecography, 40, 606617, https://doi.org/10.1111/ecog.02205.
Yu, Y., J. P. Dunne, E. Sheviakova, P. Ginoux, S. Malyshev, J. G. John, and J. P. Krasting, 2021: Increased risk of the 2019 Alaskan July fires due to anthropogenic activity [in "Explaining Extreme Events of 2019 from a Climate Perspective"]. Bull. Amer. Meteor. Soc., 102 (1), S1-S7, https://doi.org/10.1175/ BAMS-D-20-0154.1.

Yue, X., L. J. Mickley, J. A. Logan, R. C. Hudman, M. V. Martin, and R. M. Yantosca, 2015: Impact of 2050 climate change on North American wildfire: Consequences for ozone air quality. Atmos. Chem. Phys., 15, 1003310055, https:// doi.org/10.5194/acp-15-10033-2015.

Zhang, X., J. He, J. Zhang, I. Polyakov, R. Gerdes, J. Inoue, and P. Wu, 2013: Enhanced poleward moisture transport and amplified northern high-latitude wetting trend. Nat. Climate Change, 3, 47-51, https://doi.org/10.1038/nclimate1631. 
